\title{
$\frac{((-))(2)}{4002}$
}

INSTITUTO DE PESQUISAS ENERGÉTICAS E NUCLEARES

Autarquia Associada à Universidade de São Paulo

\section{Laser de Er,Cr:YSGG em condutos radiculares preparados para a cimentação de núcleos protéticos}

JOSÉ QUINTO JÚNIOR

Tese apresentada como parte dos requisitos para obtenção do Grau de Doutor em Ciências na Área de Tecnologia Nuclear - Materiais.

Orientadora:

Profa. Dra. Denise Maria Zezell 
INSTITUTO DE PESQUISAS ENERGÉTICAS E NUCLEARES

Autarquia Associada à Universidade de São Paulo

\section{Laser de Er,Cr:YSGG em condutos radiculares preparados para a cimentação de núcleos protéticos}

JOSÉ QUINTO JÚNIOR

Tese apresentada como parte dos requisitos para obtenção do Grau de Doutor em Ciências na Área de Tecnologia Nuclear - Materiais.

Orientadora:

Profa. Dra. Denise Maria Zezell 


\section{DEDICATÓRIA}

Às minhas filhas, GABRIELLE e DANIELLE, que são a razão e o sentido da minha luta diária. Obrigado por permitirem que nosso convívio transcenda a simples obrigação social ou mera condição biológica.

Este é mais um trabalho nosso!

“Ninguém galga uma colina apenas olhando-a” H.W.Beecher

À GLÁUCIA, minha amiga, eternamente minha maninha. A vida nos aproximou $e$ juntos trilhamos muitos caminhos felizes. Quanto de mim é seu? Obrigado!

"A gente pode se sentir só, no meio de muita gente amiga, se souber que não ocupa um lugar especial no coração de alguém” Anne Frank

Ao meu querido pai José Quinto, incansável batalhador A minha querida mãe Norma que sempre me apontou o norte A memória inesquecível da minha avó Rosinha, ah, quanta saudade!

Aos meus irmãos Lígia, Denise e Daniel Aos companheiros de viagem, conhecidos como família.

"A generosidade consiste em dar, antes de ser solicitado" Sabedoria Árabe 


\section{AGRADECIMENTOS}

A Profa. Dra. Denise M. Zezell, meu sincero reconhecimento pela sua dedicação profissional, competência em fazer ciência e a coragem de assumir alunos das mais diversas áreas do conhecimento conseguindo fazer um amalgama de ciência interdisciplinar.

Ao superintendente do IPEN Prof. Dr. Nilson Dias Vieira Jr. exemplo de pesquisador, de caráter e competência.

Ao Prof. Dr. Carlos de Paula Eduardo por seu empreendedorismo, visão e dedicação a odontologia.

Ao Prof. Dr. Carlos Eduardo Francci, pela precisa e preciosa contribuição.

À Profa. Dra. lara Augusta Orsi, dedicada professora e competente pesquisadora que tive o privilégio de conviver.

Ao Prof. Dr. José Eduardo Pelizon Pelino, exemplo de integridade, honestidade de princípios e amizade.

Ao auxílio enriquecedor das sugestões dos Prof. Drs. Sonia L. Baldochi. Sheila C. Gouw e José Luis Lage Marques, nas fases de seminário de área e qualificação para este trabalho.

Ao mestrado profissionalizante laser em odontologia, e a todos que se dedicam ou dedicaram a ele, permitindo que muitos, com eu, tivéssemos acesso à pesquisa.

“Um expert é uma pessoa que cometeu quase todos os erros possíveis em uma determinada área."- Niels Bohr 
A todos os pesquisadores do IPEN com os quais tenho a satisfação da convivência, aos Profs. Anderson Zanardi de Freitas, Eduardo Landulfo, Gessé E. Calvo Nogueira, Lilia Coronato Courrol, Laércio Gomes, Martha Simões Ribeiro, Marcos Raele, Ricardo Samad, Wagner de Rossi, José Manzoli e meu orientador de mestrado, Niklaus U. Wetter, o suíço mais brasileiro que conheço.

Aos colaboradores e amigos do IPEN Fernando Moreira, Elsa, Dorinha, Valdir (biblioteca), Djalma (CTR), Ana Cláudia, Verinha (CPG), Sueli, Valdir de Oliveira, Paulo, Marcos, Dona Marta, obrigado pela dedicação e carinho. Ao Alessandro Deana, pelo auxílio prestado.

Aos queridos colegas de laboratório e alunos Carolina, Claudia Zamataro, Moisés, Thiago, Vivi, Paulo, Marcelo, Renato Prates, Ilka, Melissa, Ana Claudia, Felipe, Juca, obrigado pela troca de conhecimentos

"Não são os lugares que honram os homens, mas os homens que honram os lugares" Domínio público.

Aos meus amigos: Profa. Dra. Patrícia da Ana, Prof. Dr. Sérgio B. Botta, Prof. Dr. Paulo Matos, Prof. Dr. Jose Ricardo Archilla, Dra. Reugma Rego, Dra. Claudia Strefezza, Dra. Silvia Ñunes, Dr. Jose Flávio R. Torezan, Dra. Alice A. Tencer obrigado pelo convívio, pela troca de experiências, respeito profissional e atenção.

As minhas colaboradoras diretas: Ana Lídia, Bruna, Cristiane Pinheiro, Gleiciane e Vilma, que sempre me apoiaram em momentos críticos, com carinho e amizade.

Aos meus queridos colegas e amigos da 58을 turma da Faculdade de Odontologia de Ribeirão Preto-USP.

Aos meus amigos: Antônio A.B. Marchioni, Antônio C.G.Araújo, Eloy de Macedo, Pia C. Pasin, Ricardo Rossini, Roberto V. Frizzo, Selda Berger e respectivas famílias, pela paciência de ouvir um estudante entusiasmado!

Bruno, obrigado pelo seu tempo; Diva e Ivo, obrigado pelo exemplo.

"Aquele que honra e respeita o seu semelhante, será ele mesmo respeitado e honrado"- Talmude 
Ao Instituto de Pesquisas Energéticas e Nucleares (IPEN), ao Centro de Lasers e Aplicações (CLA) e ao Centro de Tecnologia das Radiações (CTR) por sua infra-estrutura, por permitir a utilização de suas dependências e equipamentos.

Ao Laboratório Especial de Laser em Odontologia (L.E.L.O.), por sua infra-estrutura, permitir a utilização de suas dependências e equipamentos. A Profa. Dra. Patrícia M. de Freitas e Profa. Dra. Ana Cecília Correa Aranha, Liliane e Joelma pela recepção sempre calorosa, carinho e respeito.

Ao Laboratório de Materiais Dentários da FO-USP, e ao aluno André de Vito, pela utilização de seus equipamentos no início deste trabalho.

Ao Banco de Dentes Humanos, e ao Comitê de Ética em Pesquisa da Faculdade de Odontologia da Universidade de São Paulo, pela cessão dos dentes humanos que utilizei no presente trabalho e pela assistência sempre imediata.

Ao CEPOF-FAPESP (Centro de Pesquisa Inovação de Difusão em Óptica e Fotônica), processos CEPID 98/14270-8 e 05/51689-2, por permitir a aquisição de equipamentos indispensáveis para a realização deste trabalho, tais como a câmera termográfica e o laser de Er,Cr:YSGG.

A CAPES, processos PROCAD 0156/01-9 e 0349054 pelo auxílio financeiro em todos os momentos da realização deste trabalho.

Ao CNPq, pelo financiamento parcial deste trabalho com o programa Institutos do Milênio (Processo 420177/2005-1) e INCT de fotônica.

A todos que contribuíram direta ou indiretamente para a realização deste trabalho, meus sinceros agradecimentos.

"Nenhum homem é uma ilha isolada; cada homem é uma partícula do continente, uma parte da terra; se um torrão é arrastado para o mar, a Europa fica diminuída, como se fosse um promontório, como se fosse a casa dos teus amigos ou a tua própria; a morte de qualquer homem diminui-me, porque sou parte do gênero humano. E por isso não perguntes por quem os sinos dobram; eles dobram por ti”.

John Donne 


\title{
Laser de Er,Cr:YSGG em condutos radiculares preparados para a cimentação de núcleos protéticos
}

\author{
JOSE QUINTO JUNIOR
}

\begin{abstract}
Resumo
O objetivo deste estudo é avaliar a influência da irradiação com laser de Er,Cr:YSGG no espaço protético de condutos radiculares preparados para a fixação de pinos em fibra de vidro reforçados (FRC Postec®), avaliando-se o comportamento de três diferentes técnicas adesivas (self-etching=Panavia $\mathrm{F}^{\circledR}$; total-etching= Excite DSC $\AA$ + Variolink $I \circledast$ e self-adhesive= RelyX Unicem Aplicap $\AA^{\circledR}$. Observaram-se as orientações da norma ISO-TS 11405 para a preparação das raízes dentais unirradiculares humanas. As amostras foram separadas na altura da junção amelo-dentinaria, tratadas endodonticamente com instrumentação rotatória e seladas com técnica de condensação lateral. Foram utilizados dois tipos diferentes de pontas de safira para irradiação intracanal o axial (Z4, $400 \mu \mathrm{m}$ de diâmetro) e o radial ou side firing (RFT4, 415 $\mu \mathrm{m}$ de diâmetro) com densidade de energia de $40 \mathrm{~J} / \mathrm{cm}^{2}$. Esta densidade de energia foi obtida como parte deste experimento, analisando-se diversos parâmetros de energia com os resultados morfológicos e térmicos obtidos. Nesta densidade, obtive-se grande quantidade de túbulos dentinários abertos e variação de temperatura segura para uso clínico. Cada raiz foi irradiada em cinco movimentos circulares, de apical para cervical, com intervalo de 20 segundos, entre elas. Os FRC Postec foram cimentados imediatamente após a irradiação e divididos randomicamente em nove grupos $(n=10)$. Cada raiz foi seccionada em 6 discos de $1 \mathrm{~mm}$ de espessura para ensaio do tipo push-out, para a obtenção da força máxima de ruptura, e posterior cálculo da resistência de união adesiva em função da área de superfície do núcleo deslocado, resultando na pressão em MPa. A resistência de união adesiva nos grupos irradiados foi estatisticamente superior do que os grupos controle. Foram avaliadas as diferenças na resistência de união adesiva em diferentes porções do núcleo (cervical, médio e apical), onde o sistema adesivo tipo self-adhesive (RelyX Unicem Aplicap) teve o melhor resultado para os grupos irradiados. Avaliou-se por técnica de FTIR as diferenças químicas ocorridas na dentina intrarradicular irradiada com laser de Er,Cr:YSGG, em diferentes porções
\end{abstract}


(cervical, médio e apical) em função da orientação dos túbulos. Foram observadas nos espectros de FTIR alterações na intensidade das bandas de algumas moléculas, indicando variação na quantidade da parte orgânica (amida I e amida II) após a irradiação, nas diferentes regiões dentais em função do feixe laser sobre a orientação dos túbulos dentinários, sem causar alterações na sua composição. Essas diferenças podem interferir no resultado da resistência de união adesiva. A técnica de utilização de laser de $\mathrm{Er}, \mathrm{Cr}$ : YSGG em dentina radicular pré-cimentação de núcleo protético aumenta a resistência de união adesiva, na dependência do cimento utilizado. 


\title{
The utilization of Er,Cr:YSGG laser in prosthetic post space preparation before post placement \\ JOSE QUINTO JUNIOR
}

\begin{abstract}
The aim of this study was to evaluate the influence of the Er,Cr:YSGG laser irradiation in the prosthetic post space before FRC Postec placement using three different adhesive systems (self-etching- Panavia F; total-etching- Excite DSC + Variolink II e self adhesive - RelyX Unicem Aplicap). According to ISO-TS 11405, sectioned at the CEJ, human dental single roots were endodontically treated with rotatory instruments and filled with gutta-percha points and sealer. Were used at $40 \mathrm{~J} / \mathrm{cm}^{2}$ an axial Z4 laser tip (400 $\mu \mathrm{m}$ diameter) and a radial (side firing) RFT4 laser tip (415 $\mu \mathrm{m}$ diameter). This density of energy was experimentally determinated observing morphological changes in SEM images due to an increase range in the energy applied to dentinal root canal surface. At the length between 32 and $49 \mathrm{~J} / \mathrm{cm}^{2}$ most of the intracanal dentinal tubules were open. The temperature increase was within the biological safe suggesting a feasible clinical use. Each root canal was irradiated five times with helicoidal movements from apical to cervical, with 20 seconds interval. FRC Postec were immediately cemented and randomly divided in nine groups $(n=10)$. Each root canal was cut in six discs for push out test, were the maximum failure load was obtained and the bond strength was calculated as a function of post bonded area. The bond strength for the irradiated groups was superior among all control groups. The evaluation of bond strength among root region (cervical, middle and apical) was performed and differences were observed. The self-adhesive (RelyX Unicem Aplicap) system was noted superior among all irradiated groups and all regions. Chemical changes were analyzed by FTIR due to dental root portion and dentinal tubules orientation to laser beam direction. The FTIR spectra obtained indicated changes due to tubules orientation and root canal portion irradiated such as the proportion among the compositional ratio without causing chemical changes. These compositional ratio alterations may affect the bond strength results. The irradiation with $\mathrm{Er}, \mathrm{Cr}$ :YSGG laser on dentinal walls of a prosthetic post space preparation before the post
\end{abstract}


cementation, as suggested in this study, may increase the bond strength between the post and root canal dentin depending upon the luting cement that is used. 
ÍNDICE

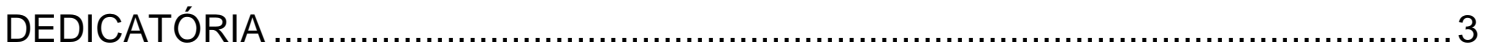

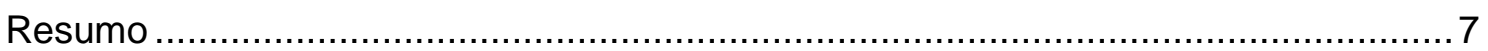

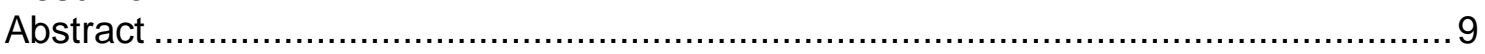

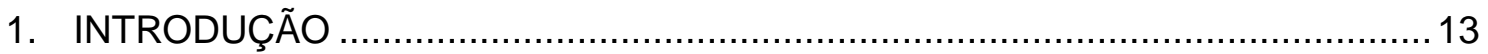

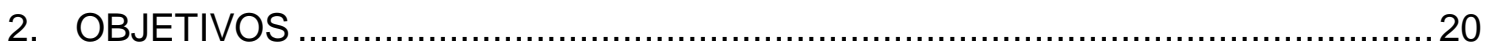

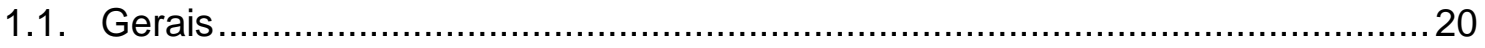

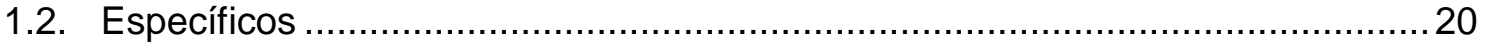

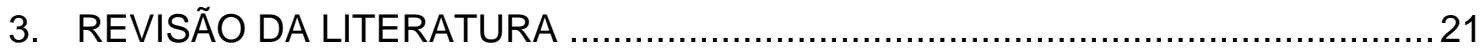

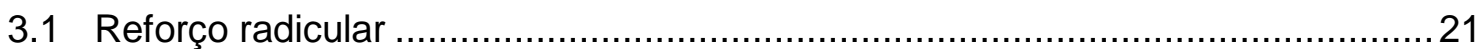

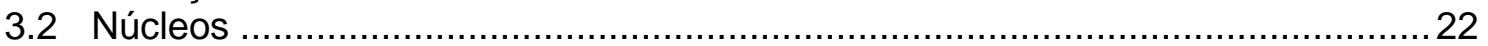

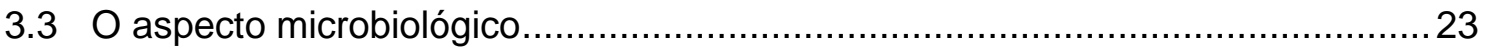

3.4 Aspectos físico-químicos da dentina.........................................................26

3.5 Limpeza e desinfecção da dentina antes da colocação de núcleo.......................28

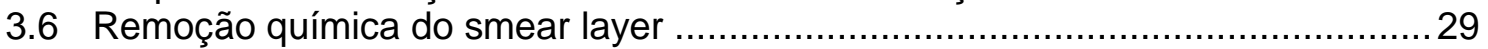

3.7 Laser de Er;Cr:YSGG sobre dentina ...........................................................

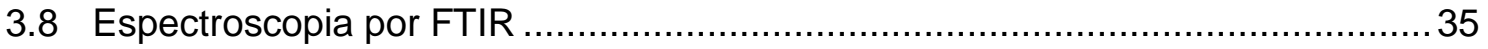

3.9 Redução bacteriana com laser de Er,Cr:YSGG …………………………....35

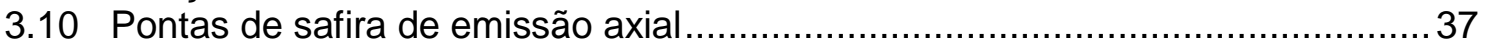

3.11 Pontas de emissão radial (side firing) ……………................................ 38

3.12 Remoção do smear layer com laser de Er;Cr:YSGG .................................... 39

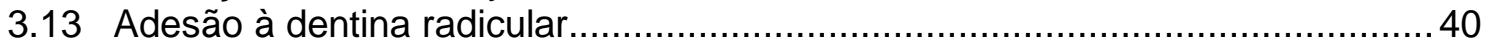

3.13.1 Total-etching (etch and rinse) .......................................................... 40

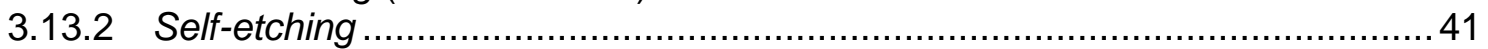

3.13.3 Self-adhesive

3.14 Ensaio mecânico: Teste de push-out ………………...................................... 46

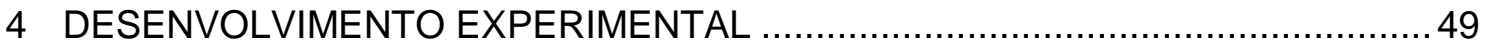

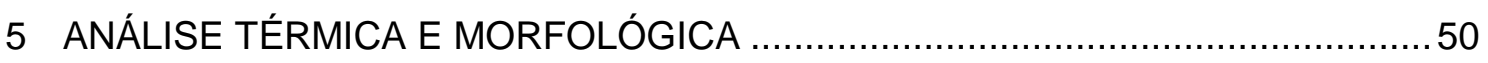

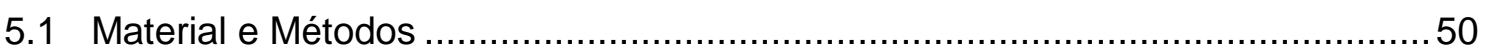

5.1.1 Preparo dos espécimes para tratamento endodôntico inicial............................50

5.1.2 Formação dos grupos de estudo..............................................................51

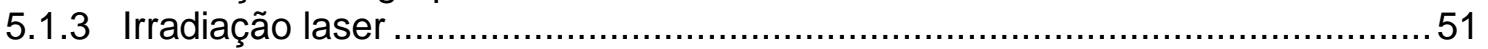

5.1.4 Avaliação térmica.................................................................................53

5.1.5 Analise morfológica por Microscopia Eletrônica de Varredura............................53

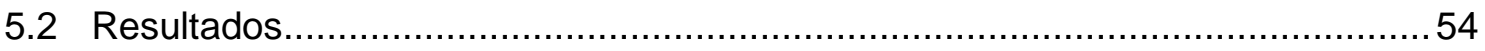

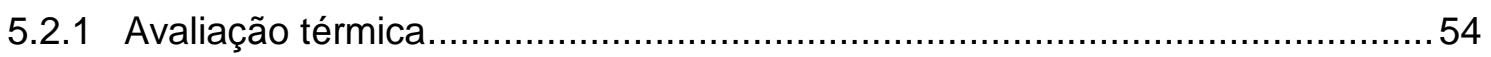

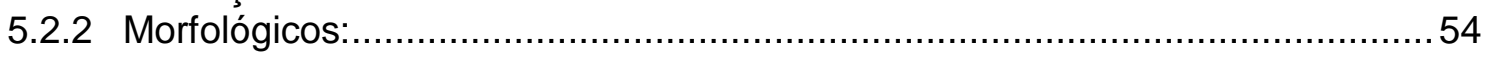

6 ANÁLISE POR FTIR (influência do eixo de orientação do feixe laser $x$ túbulos) .....59

6.1 Material e Métodos 60 
6.1.1 Exposição dos túbulos axial ou perpendicularmente ao corte. ........................60

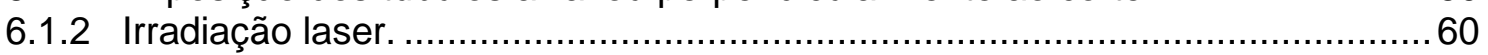

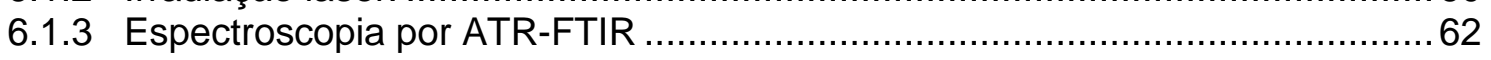

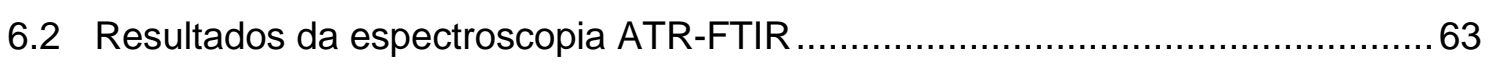

7 ANÁLISE DE ENSAIOS MECÂNICOS DE PUSH-OUT .....................................66

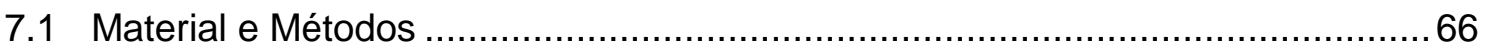

7.1.1 Preparo dos espécimes para tratamento endodôntico inicial............................66

7.1.2 Preparo dos condutos radiculares para os núcleos em fibra..........................68

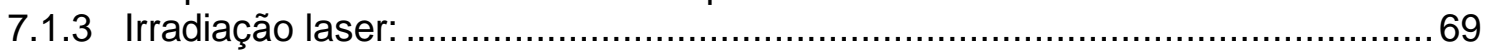

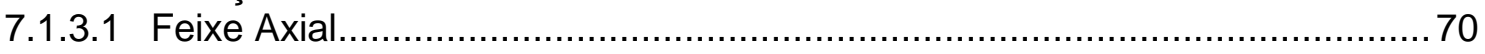

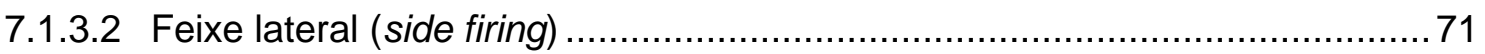

7.1.4 Preparo das superfícies dos pinos de fibra. ................................................ 72

7.1.5 Cimentação de núcleos e formação dos grupos:..........................................72

7.1.5.1 Cimentação com técnica de total-etching: .............................................. 74

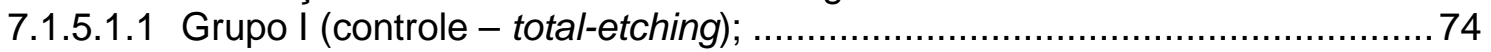

7.1.5.1.2 Grupo IV (irradiado axial - total-etching); ;............................................ 74

7.1.5.1.3 Grupo VII (irradiado radial ou side firing - total-etching). ........................... 74

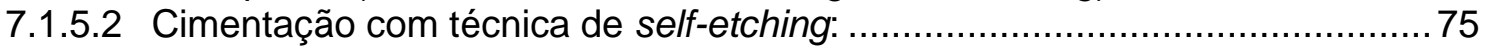

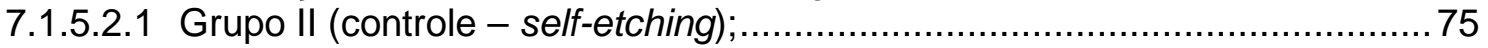

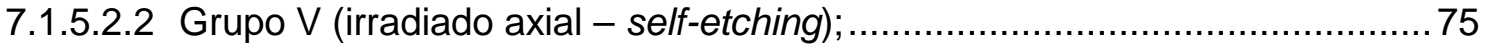

7.1.5.2.3 Grupo VIII (irradiado radial ou side firing - self-etching) ............................. 75

7.1.5.3 Cimentação com técnica de self-adhesive: ................................................ 76

7.1.5.3.1 Grupo III (controle - self-adhesive); ...................................................... 76

7.1.5.3.2 Grupo VI (irradiado axial - self-adhesive); ............................................ 76

7.1.5.3.3 Grupo IX (irradiado radial ou side firing - self-adhesive)............................ 76

7.1.6 Corte do espécime em discos para ensaio (corpos de prova)........................77

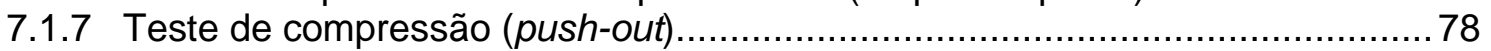

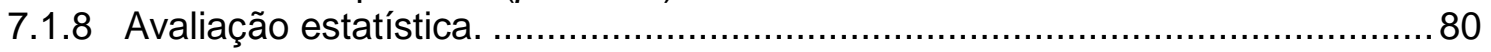

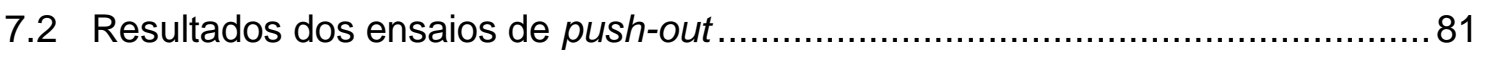

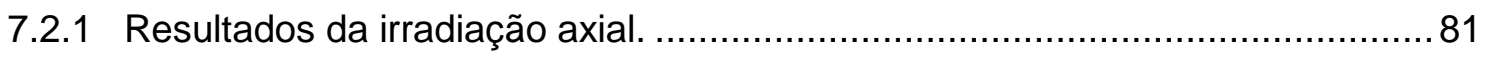

7.2.1 Resultados da irradiação radial (side firing) : ........................................... 84

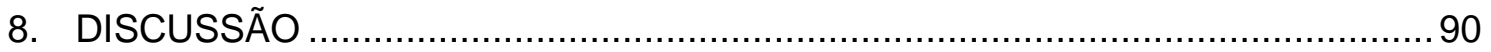

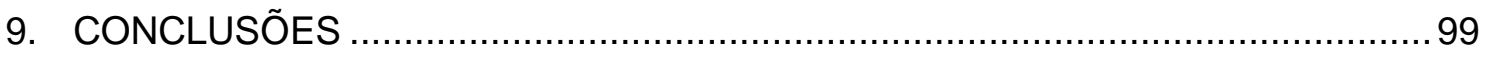

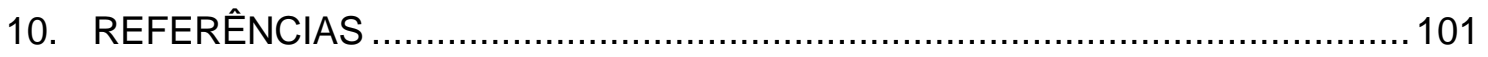




\section{INTRODUÇÃO}

Um núcleo dental é colocado em raízes dentais que foram tratados endodonticamente, fazendo parte do processo de reconstrução dental. Muitas vezes pode significar a fase final de um processo infeccioso e de destruição dental, onde microorganismos contaminaram a dentina intracanal radicular. $\mathrm{O}$ tratamento endodôntico é o procedimento que visa desinfetar os canalículos dentinários, porém implica em mais perda de substância dental. O núcleo deve estar perfeitamente aderido às paredes dentinárias para a adequada distribuição de forças e reforço de estrutura dental remanescente.

Durante os próprios procedimentos odontológicos restauradores há a possibilidade de deposição de mais contaminantes, entre a parede interna do canal e o núcleo instalado resultando em infiltração marginal. Essa infiltração leva a diminuição da retenção de próteses, sendo uma porta de entrada para a infecção por microorganismos presentes na cavidade oral. Esse círculo vicioso leva em casos extremos, a perda do elemento dental. A obtenção de uma superfície do canal radicular limpa, isenta de contaminantes e que resulte em bom imbricamento mecânico ao núcleo, não é uma tarefa trivial.

O smear layer é a deposição de resíduos do próprio material biológico que fica aderido nas paredes do conduto radicular, causando a obliteração dos túbulos dentinários. Ele pode ser considerado como o principal dos contaminantes. A produção de smear layer pode ocorrer durante o processo de tratamento do canal radicular e também no preparo do conduto radicular para a colocação de núcleo. 
Além do smear layer temos também outros contaminantes inerentes ao processo de obtenção ou colocação dos núcleos. Muitos desses processos são clínicos e necessários, mas, deixam resíduos intracanal radiculares que podem interferir na adesão. Podemos citar como alguns exemplos:

- A Remoção deficiente de excessos do cimento obturador do canal e dos cones de guta percha, utilizados na técnica de finalização da terapia endodôntica;

- A utilização de resina acrílica e vaselina (ou similar) dentro do conduto radicular para facilitar a modelagem do núcleo;

- Utilização de cimento temporário na entrada do conduto e ou algodão entre consultas, tanto na fase de tratamento endodôntico, quanto nas consultas necessárias até a cimentação definitiva do núcleo.

- Colocação de núcleo provisório com trabalhos protéticos igualmente provisórios, cimentados às paredes dos condutos radiculares;

- Atrito do núcleo definitivo nas paredes do conduto durante o processo de ajuste do mesmo deixando resíduos nas mesmas;

- A provável contaminação por saliva dos condutos entre o final do tratamento endodôntico e as consultas para preparo, moldagem e cimentação definitiva do núcleo.

Os núcleos em materiais resinosos ganharam espaço para utilização quer seja pela facilidade de execução, pelo resultado estético obtido ou questionamentos técnicos. Há uma corrente de pesquisadores que afirmam que os núcleos devam ter o módulo de elasticidade próximo ao da dentina.

Os núcleos em fibra de vidro reforçados são encontrados em kits com diversos diâmetros, compatíveis com o diâmetro dos condutos que serão 
colocados. São acompanhados por instrumentos rotatórios para utilização em contra-ângulo de baixa rotação odontológico. Esses instrumentos rotatórios dão a conformação final do conduto que receberá o núcleo. Sua execução é muito simples e como as suas dimensões são uniformizadas, tornam-se uma opção muito interessante em estudos seriados como desta.

Para a fixação de núcleos de fibra de vidro reforçado são usados cimentos resinosos do tipo "dual", ou seja, dupla polimerização, tanto autopolimerizam como também são sensíveis a ação da luz.

Os cimentos resinosos do tipo dual podem ser encontrados em três sistemas diferentes, o total-etching, o self-etching e o self-adhesive.

O sistema total-etching (etch \& rinse) requer o condicionamento da superfície a ser aderida com ácido, para posterior aplicação de um adesivo e para finalmente receber então o cimento. No sistema self-etching, o condicionamento ácido é executado pelo próprio primer que interage com a superfície dentinária (e smear layer) com posterior aplicação do cimento adesivo. No sistema self-adhesive, não há preparo algum na dentina, apenas a limpeza mecânica e aplicação do cimento.

O efeito desejado neste estudo é o de promover a limpeza intracanal, removendo principalmente o smear layer, entre outros contaminantes, e com a abertura dos túbulos obtida, favorecer o melhor imbricamento dos cimentos usados em prótese dental para a fixação de núcleos. Uma alternativa para se obter essa limpeza intracanal é a irradiação laser.

O laser de Er,Cr:YSGG, emite em $\lambda=2,79 \mu \mathrm{m}$, possui interação ressonante com água e com a hidroxiapatita que são os principais componentes do esmalte e dentina causando alterações físicas como por 
exemplo, a ablação nesses tecidos dentais. A ablação é um processo de remoção explosiva de tecido, onde os fótons são absorvidos pelo tecido alvo, causando um rápido aumento da temperatura. Na dentina, há a elevação da temperatura (entre $300^{\circ} \mathrm{C}$ e $800^{\circ} \mathrm{C}$ ) na área focal, au menta muito a pressão da água intersticial o que leva a ruptura do tecido adjacente, removendo-o juntamente com o vapor de água formado.

O laser de Er,Cr:YSGG usado com energia acima do limiar de ablação pode promover a abertura dos canalículos dentinários. $\mathrm{O}$ processo ablativo remove o smear layer e outros detritos da superfície dentinária radicular.

Os protocolos de aplicação de energia com laser Er,Cr:YSGG intracanal, para obter-se o máximo de abertura dos túbulos, ainda não estavam definitivamente estabelecidos.

Um dos cuidados ao se trabalhar com laser de alta intensidade de energia na área de saúde é o de se obter o efeito desejado sem causar danos a própria estrutura ou as adjacentes. Para tanto, a relação entre a menor energia necessária para o melhor resultado é uma preocupação constante. Neste caso, o efeito térmico é uma preocupação muito relevante. A energia laser aplicada, o efeito obtido, a elevação de temperatura, o tecido alvo e suas propriedades ópticas são parâmetros muito importantes que devem sempre ser observados.

Neste estudo, pretende-se obter um protocolo seguro e confiável de irradiação laser intracanal, obtendo-se o maior número de túbulos dentinários abertos, diminuição do smear layer e menor remoção de tecido dental. Para a avaliação dos parâmetros laser e seus efeitos sobre o tecido alvo, utiliza-se como recursos técnicos um medidor de energia por pulso, que avalia a energia 
ou potência real entregue pelo feixe laser; uma câmara termográfica, para avaliar as alterações de temperatura e a microscopia eletrônica de varredura, para visualizar os efeitos produzidos.

Outro efeito que pode ser obtido pelo laser de Er,Cr:YSGG sobre a superfície dentinária é a redução bacteriana, extremamente significativa, do conduto radicular. Utilizando-se parâmetros de energia adequados para a desinfecção do conduto, antes da cimentação de um núcleo, pode ser obtida uma aplicação clínica muito importante.

Uma característica pouco estudada é a influência da direção da irradiação laser em relação à direção dos túbulos dentinários. A dentina não é isotrópica frente a um feixe de luz, ou seja, o comportamento do feixe não é uniforme em toda a sua extensão. Há diferenças fundamentais quanto a direção ou local do dente que incidimos um feixe laser. Se os feixes incidirem no mesmo sentido dos túbulos dentinários ou nas paredes dos mesmos, poderemos obter diferentes resultados quanto às alterações estruturais, químicas e etc. Além da diferença no sentido dos túbulos, a dentina apresenta diferenças na densidade de túbulos por área de dentina, no diâmetro dos túbulos, na quantidade de cruzamentos e anastomoses, assim como, há diferença entre a densidade óptica da dentina intertubular $(n=1,45)$, peritubular $(n=1,65)$ e solução intertubular $(n=1,33)$. Essas diferenças são muito significativas em relação à porção do dente observada. Por esse conjunto de variáveis, o efeito do laser pode ser considerado anisotrópico sobre a superfície dentinária, e merece ser estudado.

Os equipamentos de laser de Er,Cr:YSGG usados em clinicas odontológicas possuem um sistema de entrega de feixe por fibras do tipo 
hollow fiber acopladas por meio de lentes e espelhos a uma peça de mão, que se assemelha a uma "caneta" de alta rotação.

Há pontas de safira apropriadas, que encaixam nessa peça de mão. São fibras intracanal de pequena dimensão que possuem espessuras compatíveis ao diâmetro interno de um conduto radicular. O seu modo de trabalho é em contato com as paredes dentinárias.

A maioria das fibras, ou também chamadas de pontas de safira para uso endodôntico, transmite o feixe, que é emitido pela extremidade, no mesmo eixo da fibra, axiais, ou seja, com pequena abertura numérica. Mas, se atentarmos para o fato que, o conduto radicular tem o seu longo eixo perpendicular a maioria dos túbulos dentinários, teremos, então, que essa fibra emite o feixe laser perpendicular aos túbulos.

Para que tenhamos o melhor efeito intracanal essa fibra tem que ser girada e pressionada contra as paredes dos condutos em movimentos circulares. A habilidade técnica do operador desta fibra é um dos fatores essenciais de influência dos resultados.

Foi desenvolvida comercialmente uma ponta intracanal que possui sua emissão com grande abertura numérica e reduz essa dificuldade técnica. Essas pontas são denominadas de emissão radial ou side-firing. Essa alteração permite então que o feixe laser seja direcionado radialmente a fibra praticamente no mesmo eixo dos túbulos dentinários, interagindo de maneira mais adequada e eficaz com a dentina.

A utilização do laser de Er,Cr:YSGG com sistema de entrega de feixe por fibra de emissão side firing pode significar um método muito útil na prática clínica diária dos profissionais que se dedicam à prótese. No melhor do nosso 
conhecimento não foram encontrados na literatura trabalhos que utilizem irradiação intracanal com fibra de emissão side firing antes da cimentação de núcleos protéticos.

Neste estudo foi utilizado laser de Er,Cr:YSGG com os dois tipos de ponta (axial e side firing) imediatamente antes da cimentação do núcleo em fibra de vidro reforçada (FRC) e em sua fixação há utilização de três tipos de cimentos resinosos, representando diferentes técnicas.

O método de ensaio mecânico de push-out foi a técnica utilizada para se avaliar a resistência de união adesiva. Quanto maior a força adesiva indica melhor qualidade de imbricamento dos cimentos aos túbulos dentinários, melhor a limpeza conseguida e consequente potencialização das propriedades de adesão do cimento utilizado.

Justifica-se, assim, o interesse no desenvolvimento deste trabalho e sua aplicabilidade, possibilitando um novo campo de utilização para os lasers de Er,Cr:YSGG, que são uma realidade na vida clínica dos cirurgiões dentistas. 


\section{OBJETIVOS}

\subsection{Gerais}

O presente trabalho tem por objetivo avaliar a resistência mecânica à compressão de núcleos cimentados com três diferentes técnicas de cimentos resinosos em raízes dentais humanas, irradiadas ou não por laser de Er,Cr:YSGG, com entrega de feixe axial ou radial.

\subsection{Específicos}

- Determinar condições de irradiação seguras;

- Avaliar a limpeza da superfície após a irradiação;

- Avaliar a influencia da orientação dos túbulos em função da direção de irradiação;

- Avaliar a pressão necessária para remoção dos núcleos 


\section{Revisão da literatura}

\subsection{Reforço radicular}

A resistência da estrutura dental é afetada, significativamente, pela perda da substância dental quer seja pela extensão de uma lesão cariosa ou da sua restauração associada ${ }^{1}$. Os núcleos são recomendados em casos que haja falta de estrutura dental ao suporte do procedimento restaurador ${ }^{2}$

A colocação de um núcleo intracanal radicular sempre ocorre em raízes endodonticamente tratadas. A perda da vitalidade pulpar, seguida por tratamento endodôntico adequado, não causa alterações biomecânicas por si deletérias, onde não são notadas alterações significativas na composição ou umidade da dentina ${ }^{1,3}$.

Procedimentos protéticos em dentes endodonticamente tratados as melhores abordagens são: a- minimizar o desgaste dental, especialmente da região coronária, para a criação do efeito de ferulização. b- usar preferencialmente procedimentos adesivos tanto em coroas como em raízes, quando for necessário procedimentos de reforço de estrutura; c- uso de núcleos em materiais com módulos de elasticidade próximos ao da dentina.

O módulo de Young ou módulo de elasticidade é um parâmetro mecânico que proporciona uma medida da rigidez de um material sólido. Os

módulos de elasticidade em tensão e compressão são aproximadamente iguais. O módulo de elasticidade também é chamado de módulo elástico e coeficiente de elasticidade. A dureza da dentina aumenta a medida que se distancia da junção amelo-dentinária. Portanto as menores medidas estão mais próximas da câmara pulpar. Seus valores variam de $17,7 \mathrm{GPa}$ a 29,7 GPa ${ }^{4,5}$. 
Os insucessos biomecânicos dos elementos dentais com tratamentos endodônticos ainda são um problema crítico à dentística restauradora ou prótese ${ }^{6}$. "Sob o ponto de vista mecânico, a interface entre a dentina radicular e

o núcleo é sempre o ponto crítico, não importando a qualidade ou tipo do material empregado" conclui-se em uma revisão sistemática sobre núcleos entre 1990 e $2005^{7}$.

\subsection{Núcleos}

Os diferentes tipos de material empregados na confecção de núcleos intracanal radiculares apresentam módulos de elasticidade variados. Os metais e as cerâmicas apresentam valores muito acima do que o da dentina (de 17,7 GPa a 29,8 GPa, de acordo com a posição), por exemplo 110 GPa (titânio), 200 GPa (aço inoxidável e zircônia) e 300 GPa (óxido de alumínio). O conceito da utilização de materiais muito resistentes dentro do conduto radicular, ainda corrente, baseia-se na idéia de "reforçar" a estrutura dental ${ }^{1}$. Este conceito, porém, está sendo questionado, pois se argumenta que existam limitações no que concerne a resistência, pois a adesão do cimento com paredes dentinárias ou entre o núcleo e o cimento são o ponto mais frágil ${ }^{56}$.

Os núcleos metálicos fundidos apresentam uma resistência à fratura superior aos núcleos em resina reforçada em teste de cisalhamento, além de adaptação mais precisa. Mas, ao mesmo tempo, aumentam, significativamente, o risco de perda do elemento dental, uma vez que a fratura na força de cisalhamento produz fraturas dentais nas raízes muito mais significativas ${ }^{8}$. Estes tipos de núcleos tendem a distribuir a força intracanal, com concentração do esforço na porção apical, o que explica a maior incidência de fraturas radiculares. 
Os núcleos em resina reforçada apresentam-se como uma opção mais simples de reforço de estrutura, mas apresentam uma grande variedade de composição e forma. O contorno de núcleo ideal é o que apresenta forma cilíndrica na porção coronariana e cônica apicalmente. O comportamento estático ou dinâmico do núcleo varia em função do tipo de material, processo de fabricação, da interface com a resina, com o tratamento dado a sua superfície além do módulo de elasticidade.

Os núcleos em fibra de vidro reforçados apresentam-se atualmente como uma solução clinica altamente favorável e são resistentes ao teste de fadiga ${ }^{1}$. A distribuição de forças oclusais se dá ao longo da interface adesiva, sendo uniformemente distribuída em toda a estrutura dental e adjacência ${ }^{7}$.

O uso de cimentos resinosos, na fixação de núcleos em fibra de vidro reforçados, é a opção mais adequada, quer seja pela facilidade de manipulação ou pelas características físicas e químicas mais compatíveis ao tipo de núcleo ${ }^{9}$. A técnica de cimentação adesiva independe do grau de habilidade do operador ${ }^{10}$.

\subsection{O aspecto microbiológico}

O tratamento endodôntico e os procedimentos restauradores visam à desinfecção e proteção da estrutura dental frente a novas agressões ${ }^{11}$. Uma vez que o núcleo só é executado em situações de pós-tratamento endodôntico, podemos, então, dizer que esta etapa a afeta diretamente.

A invasão de microorganismos nos túbulos dentinários ocorre quando há uma solução de continuidade na camada de esmalte ou cemento, que protegem o dente. Os produtos bacterianos se difundem através dos túbulos dentinários em direção ao complexo dentina-polpa, provocando alterações e 
possível quadro inflamatório. Se não houver um tratamento que elimine a invasão de microorganismos e seus subprodutos (como endotoxinas), culmina em pulpite, podendo evoluir a uma necrose pulpar e uma possível infecção do sistema do canal radicular e periapical ${ }^{12}$.

Estudos mais recentes e com técnicas cada vez mais sensíveis conseguiram identificar através de seqüenciamento genético mais de 700 tipos ou filotipos de microorganismos na cavidade oral saudável. Pode-se observar que algumas espécies são específicas a determinados indivíduos e, portanto encontra-se em diversos sítios bucais da mesma pessoa. Porém outras espécies são sito específicas. Vale salientar que nesse estudo não foram incluídos microorganismos patogênicos ${ }^{13}$. A importância de salientar esta informação é de reforçar o fato de que a cavidade oral é um ambiente altamente infectado e que devemos ter sempre isso em mente durante qualquer tratamento realizado em odontologia.

Nos túbulos dentinários predominantemente temos microorganismos gram-positivos aeróbicos (Eubacterium spp., Propionibacterium spp., Bifidobacterium spp., Peptostreptococcus micros, e Veillonella spp.), mas encontramos menos frequentemente anaeróbios (Porphyromonas spp.). Os Streptococos que são os mais comuns de se encontrar nos túbulos dentinários conseguem aderir aos elementos presentes nos túbulos dentinários (como o colágeno tipo I) estimulando sua fixação e proliferação. Decorre deste processo a interação dos Streptococos com outros microorganismos, facilitando a invasão bacteriana ${ }^{12}$.

O uso do laser de diversos comprimentos de onda para a redução bacteriana intracanal é um procedimento que está sendo estudado há décadas 
e podemos considerá-lo estabelecido como terapia complementar no tratamento endodôntico. A exemplo do laser de Nd:YAG, sua atuação ocorre não apenas na superfície como também em camadas mais profundas da dentina ${ }^{14}$.

Determinados microorganismos patogênicos tem a capacidade de penetrar ou causar efeitos na dentina radicular em profundidades de até $1 \mathrm{~mm}$ $(1000 \mu \mathrm{m})$ ao passo que as soluções irrigantes usualmente empregadas em tratamentos endodônticos conseguem penetrar até $100 \mu \mathrm{m}^{15}$.

Há o fato clínico que o núcleo nem sempre é colocado no mesmo instante do final do tratamento endodôntico. A cimentação tardia de um núcleo ocorre quer seja por ser executada por profissionais diferentes, por uma questão de tempo do tratamento ou técnica.

Em estudo comparativo entre a resistência de união adesiva de núcleos em resina reforçada (RFC) cimentados imediatamente, 24 horas ou uma semana após o término do tratamento endodôntico, os grupos de cimentação tardia foram superiores. Independente do tipo ou marca comercial do núcleo ou do cimento resinoso utilizado, as forças de adesão foram estatisticamente superiores nos casos de preparo do espaço protético e cimentação de núcleos nos grupos de espera, ou seja, onde a colocação do núcleo foi feita em intervalos de tempos maiores que um dia depois do canal tratado ${ }^{16}$.

Em estudo com setenta dentes humanos, que após tratamento endodôntico, foram removidos $10 \mathrm{~mm}$ do selamento (a exemplo do que ocorre em um preparo para núcleo) foram selados com cimento temporário. Os espécimes foram imersos em saliva humana e analisou-se os diferentes graus de infiltração ao longo do tempo. Ao final de 60 dias $90 \%$ dos espécimes 
estavam contaminados. Mostrou-se assim que em nenhuma técnica testada selamento o coronário temporário é satisfatório, quando submetido ao ambiente contendo saliva ${ }^{17}$.

Este fato levanta o questionamento de como é o estado de colonização bacteriana do sítio preparado para receber o núcleo protético no instante de sua cimentação final ${ }^{18}$. Em situações clínicas correntes muitas vezes o próprio especialista em endodontia deixa o espaço para o recebimento do núcleo já preparado para posterior cimentação. Até o instante, salvo melhor avaliação, não consta em literatura estudos que demonstrem como é a colonização bacteriana nestes sítios em caso de cimentações tardias, quais os tipos de microorganismos presentes, ou qualquer outra informação pertinente desta situação tão comum na prática clínica.

\subsection{Aspectos físico-químicos da dentina}

O conhecimento detalhado da estrutura dentinal e em especial dos túbulos dentinários é essencial para o entendimento da permeabilidade dentinária e assim ter condições de interpretar adequadamente os resultados obtidos nos trabalhos que investigam a adesão na dentina ${ }^{19}$.

A densidade de túbulos na dentina pode apresentar uma variação entre 7 à 30 túbulos por $100 \mu \mathrm{m}$, o que corresponde a uma variação entre 4.900 a 90.000 túbulos por $\mathrm{mm}^{2}$. O diâmetro dos túbulos pode variar entre 1 a $3 \mu \mathrm{m}^{19}$. Isto significa uma diferença muito acentuada, o que corresponderá a diferenças na quantidade de substâncias inter ou peritubulares. Existem também três padrões característicos de ramificações baseados na localização, dimensões e direção que ocupam na dentina ${ }^{19}$ 
A microdureza e elasticidade da dentina peritubular e intratubular variam entre si e apresentam, também, variações em função da sua localização. A dentina peritubular apresenta módulo de elasticidade de 29,8 GPa, ao passo que a dentina intertubular varia entre $17,7 \mathrm{GPa}$ (próxima a polpa) a 21,1 GPa (radicular) ${ }^{4,5}$. Esse decréscimo na dureza pode ser atribuído às alterações da dentina intertubular ${ }^{20}$.

A densidade de túbulos por área de dentina e a variação do seu diâmetro em relação ao local do dente, podem explicar a diferença da densidade mineral bem como as variações nas propriedades da dentina ${ }^{1}$. A dureza da dentina é inversamente proporcional a densidade de túbulos ${ }^{20}$.

Medidas de dureza com a técnica de ultra-micro indentações, mostrou valores significativamente maiores de dureza e no modulo de elasticidade, em função da orientação dos túbulos dentinários. As forças aplicadas paralelas aos túbulos são maiores do que as perpendiculares ${ }^{21}$. Foram observadas alterações em testes de ensaios mecânicos de dentina, tanto em força de compressão quanto de tração, relacionados com a anisotropia na orientação dos túbulos ${ }^{22}$.

Em estudo de microscopia eletrônica de varredura, amostras de mais de trinta raízes dentais humanas, em diferentes porções, foram analisadas antes e depois do condicionamento ácido. Revelou-se uma grande variabilidade na densidade e na orientação dos túbulos em função da sua localização. $O$ resultado mostrou que a região de maior quantidade de túbulos apresentou uma maior resistência de união adesiva do cimento resinoso aplicado quanto à fixação de núcleos intracanal radiculares ${ }^{23}$. 


\subsection{Limpeza e desinfecção da dentina antes da colocação de núcleo.}

Foi reportada em literatura a utilização dos mais diferentes produtos para a limpeza e desinfecção do conduto antes da cimentação de um núcleo. Essa é uma preocupação constante a todos que se dedicam à odontologia, e em especial à prótese dental, pois o elemento dental sofreu uma série de injurias por microorganismos, mecânicas e químicas ${ }^{24}$.

Quaisquer resíduos presentes, bacterianos ou químicos, poderão ser contaminantes. Estes contaminantes nem sempre serão inertes e poderão imediatamente ou em longo prazo, deteriorar a fixação do núcleo à raiz dental. Essa redução na capacidade adesiva em dentina intracanal humana chega a $40 \%$. Se houver a presença de saliva, a perda de adesividade chegará aproximadamente a $50 \%{ }^{25}$.

A presença de água em excesso dentro do canal radicular pode representar um empecilho a mais para a adequada fixação adesiva, por isso foi proposta a utilização de etanol a 99,6\%, após o condicionamento ácido e imediatamente antes da aplicação de adesivo. Os resultados demonstraram aumento significativo da resistência de união adesiva dos núcleos a dentina radicular quando foi usado o sistema adesivo de três estágios (All Bond 2-Bisco Inc, Itasca, IL, EUA) ${ }^{26}$

Em estudo da influência de vários produtos irrigantes usados no conduto radicular antes da utilização de cimento adesivo C\&B (Parkell, Farmingdale, NY), conclui-se que a utilização de peróxido de hidrogênio ou sua combinação com hipoclorito de sódio a $5 \%$, pioram o resultado da adesão ao canal 
radicular. A conclusão do estudo é que o uso de clorehexidina é o mais adequado para não interferir na adesão à dentina intracanal radicular ${ }^{27}$

A conseqüência de uma fixação inadequada poderá levar desde o simples desprendimento da peça protética até a perda do elemento dental.

\subsection{Remoção química do smear layer}

Através de uma revisão sistemática da literatura e meta-análise sobre os efeitos do smear layer, ficou estabelecido ser fundamental a sua remoção para procedimentos adesivos do tipo total-etching. Não há como controlar o seu volume, seu diâmetro dentro do conduto ou sua composição. A maior parte de seu constituinte é água ${ }^{28}$. Possui também em seu interior bactérias com seus subprodutos e restos de tecidos necróticos. A presença do smear layer pode servir de substrato para bactérias e ser foco para contaminação em camadas mais profundas. Sua presença limita também a penetração de medicamentos, agentes desinfectantes e cimentos no interior dos túbulos dentinários ${ }^{29}$

Dentre os produtos citados em literatura para limpeza e desinfecção do conduto radicular antes da cimentação de núcleos está o clorofórmio, halotano, peróxido de hidrogênio, além do hipoclorito de sódio, que interferem nos processos adesivos ${ }^{7}$. Esses solventes têm a finalidade de remover o cimento obturador endodôntico ou a guta-percha, ainda presentes no conduto preparado para a colocação de um núcleo. A clorehexidina não aparenta ter nenhuma interferência na adesividade.

A penetração da resina nos túbulos ocorre melhor se há a remoção do smear layer. A penetração da resina na dentina intertubular ocorre com a remoção com agentes ácido-condicionantes ou quelantes ${ }^{30}$. 
Em estudo para avaliar a efetividade do uso de agentes irrigantes após o preparo de condutos preparados para núcleos, constatou-se que o uso de irrigantes afetou significativamente a superfície dentinária. Nos grupos em que foram utilizados EDTA a 17\% por um minuto, o smear layer e outros detritos foram completamente removidos ao longo de todo o conduto não importando o terço observado. Para os grupos em que se utilizou hipoclorito de sódio a 5,25\% houve remoção parcial do smear layer nas porções coronária e média, mas nenhuma remoção apical. Os túbulos permaneceram parcialmente obliterados ao longo de todo o preparo, com presença de outros detritos. Para os grupos irradiados com soro fisiológico não houve a remoção do smear layer em nenhum terço e os túbulos ficaram completamente obstruídos ${ }^{24}$.

Também com a finalidade de limpeza dos condutos preparados para a colocação de núcleos e da remoção do smear layer, foi proposta irrigação com: peróxido de hidrogênio a $5 \%$; hipoclorito de sódio a $5 \%$; combinação de peróxido de hidrogênio a $5 \%$ seguido por irrigação com peróxido de hidrogênio a 5\%; EDTA a 15\%; ácido lático $10 \%$ e ácido lático a $20 \%$. O estudo teve apenas o caráter morfológico através de imagens de microscopia. A conclusão do estudo foi que apesar da remoção mais efetiva do smear layer nos grupos em que foram irrigados com EDTA e ácido lático, resquícios ainda foram encontrados dentro dos túbulos ${ }^{31}$.

O uso de quelantes como EDTA, CDTA, EGTA, bem como o hidróxido de cálcio e o hipoclorito de sódio, largamente utilizados para irrigação endodôntica e descontaminação do conduto radicular, afetam a matriz mineral inorgânica e também o substrato orgânico. Os quelantes atuam basicamente na depleção do cálcio e nas proteínas não colagenosas, ao passo que o 
hipoclorito de sódio tem uma ação proteolítica, causando uma fragmentação das cadeias peptídicas mais longas, como o colágeno ${ }^{32} 33$.

O condicionamento ácido da dentina leva a uma profunda alteração na composição química e das propriedades físicas da sua matriz, que pode influenciar a qualidade, a força e talvez a durabilidade da adesão. As resinas podem atingir os túbulos dentinários ou a região intertubular, apenas quando o smear layer for removido ou se houver mecanismos de difusividade através do mesmo ${ }^{34}$.

\subsection{Laser de Er;Cr:YSGG sobre dentina}

O laser de Er,Cr:YSGG emite em $\lambda=2,79 \mu \mathrm{m}$ e possui interação ressonante com água e com a hidroxiapatita, que são os principais componentes do esmalte e dentina causando alterações nesses tecidos dentais. A ablação é um processo de remoção explosiva de tecido, onde os fótons são absorvidos pelo tecido alvo, causando um rápido aumento da

temperatura. Na dentina há a elevação da temperatura (entre 300 e $800{ }^{\circ}$ ) ${ }^{35}$ na área focal, aumentando muito a pressão da água intersticial o que leva a ruptura do tecido adjacente, removendo-o, juntamente com o vapor de água formado.

Em muitos estudos de biofotônica os autores assumem que a ação de fótons em tecidos biológicos é randômica e o meio isotrópico. Mas especificamente no caso de tecidos dentais, há o efeito de guias de luz. Mostrou-se que a irradiação de laser sobre cubos de dentina não tem efeito aleatório ${ }^{36}$. Para aplicações de biofotônica é de fundamental importância o 
estudo e o conhecimento da influência na micro-estrutura do tecido alvo, na propagação da luz incidente sobre o mesmo ${ }^{37}$.

A dentina humana apresenta a característica de amplificação óptica do feixe de luz incidente. Isto se deve a forte relação de dependência da direção em que o feixe é incidido sobre os túbulos de dentina. Este efeito anisotrópico da dentina foi teorizado em modelos matemáticos como obtido em experimentos $^{37}$. A anisotropia está baseada em estudos teóricos com modelo de Monte Carlo, que propõe ampliação da intensidade do feixe laser por sucessivas reflexões dentro dos túbulos dentinários. Por meio de experimentos com discos de dentina cortados com espessura de $1 \mathrm{~mm}$ colocados sobre uma grade milimetrada, verificou-se alterações significativas no modo como a luz é propagada no sentido ocluso-apical ou apico-cervical. A dentina comporta-se como uma lente, aumentando ou diminuindo o feixe de luz incidido ${ }^{38}$.

Além dos túbulos devemos considerar a influência das fibras colágenas ao incidirmos um feixe sobre a dentina. Elas são fator de atenuação sobre a reflexão do feixe laser, pois absorvem o mesmo. Em cálculos teóricos seu fator de atenuação é $\mu=0,5 \mathrm{~mm}^{-1}$. Como a sua distribuição e alinhamento são randômicos podemos assumir o seu caráter isotrópico ${ }^{38}$.

A determinação dos parâmetros de energia real que é entregue ao tecido é de suma importância para a compreensão do resultado obtido, bem como a sua segurança para utilização clinica.

Em condições ideais o feixe laser deve incidir sobre o tecido alvo na sua forma de máxima energia. Esta forma é o modo TEM $0_{00}$ (transversal eletromagnético), ou seja, quando o feixe laser possui distribuição Gaussiana. A sobreposição de pulsos, mudança de angulação do feixe, sistema de entrega 
de feixe e etc., são fatores que alteram a intensidade da energia laser entregue sobre o tecido ${ }^{39}$.

Discos de dentina obtidos de cortes longitudinais da porção coronariana de dentes humanos foram irradiados com laser de Er; Cr:YSGG com125 mJ por pulso, $20 \mathrm{~Hz}\left(16 \mathrm{~J} / \mathrm{cm}^{2}\right)$. A incidência do feixe na superfície da dentina foi perpendicular ao longo eixo do dente e portanto perpendicular ao túbulos dentinários. Utilizando-se um sistema adesivo do tipo self-etching (Clearfill SE Bond, Kuraray, Osaka, Japão), foram fixados corpos de prova produzidos com resina fotopolimerizada (Filtek Z-250, 3M Dental Products, St. Paul, MN, EUA) sobre a superfície irradiada, para ensaio mecânico de tração. Os resultados em comparação ao grupo em que a superfície foi cortada com instrumentos rotatórios de alta rotação mostraram adesões menores ao grupo laser ${ }^{40}$.

Em estudo da influencia do tempo de condicionamento acido sobre superfície dentinária coronária irradiadas com laser de Er,Cr:YSGG (4 W, 200 mJ, $20 \mathrm{~Hz} ; 71,4 \mathrm{~J} / \mathrm{cm}^{2}$ ), em discos de dentina (a orientação da irradiação é perpendicular aos túbulos, segundo esquema apresentado), mostrou piora na resistência de união adesiva. ${ }^{41}$

Em outro estudo com o laser de Er,Cr:YSGG com 2 W de potência média com $20 \mathrm{~Hz}$, com o uso de uma fibra de entrega de feixe modelo G4 de $600 \mu \mathrm{m}$ de diâmetro $\left(35,38 \mathrm{~J} / \mathrm{cm}^{2}\right)$, obteve-se superfície dentinária coronaria livre de smear layer, com túbulos abertos, dentina peritubular protuberante, com a sua superfície com aspecto desbastado ou raspado. Os resultados de resistência de união adesiva com adesivo tipo self-etching (Clearfill SE Bond, Kuraray, Osaka, Japão) foram inferiores aos obtidos com a superfície sem tratamento ${ }^{42}$. 
Contrariamente ao efeito de abertura total de túbulos, um estudo onde a

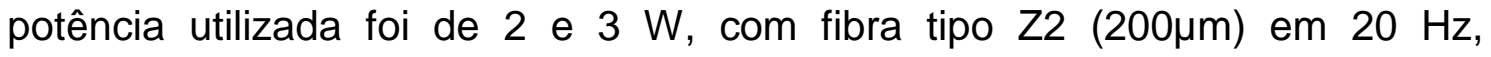
intracanal, houve a oclusão parcial e alguns pontos de total obliteração dos túbulos dentinários, quando usado intracanal com duas aplicações de apical para cervical ${ }^{43}$. Neste estudo porém não se tem referencia quanto ao uso de controle com power/energy meter para avaliar-se a energia entregue de fato ao tecido (calculando-se a densidade de energia, com valor de diâmetro [1-1e $\left.\mathrm{e}^{2}\right]$

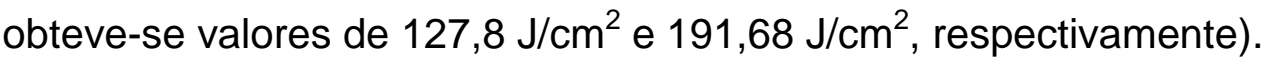

Os fótons emitidos pelo laser de Er,Cr:YSGG são fortemente absorvidos pela hidroxiapatita e água. Para um efeito de remoção do tecido dental quando em procedimentos em odontologia, é de fundamental importância a manutenção da umidade do tecido alvo e uma camada de água deve estar sempre presente durante a ablação do tecido. Concluiu-se que a pluma de ablação carrega para as paredes adjacentes a área irradiada o material retirado no processo ablativo. Se o material retirado se ficar aderido às paredes dentinárias irá interferir na eficiência dos pulsos laser subseqüentes, reduzindo o seu poder de remoção tecidual. Portanto, a manutenção de uma camada de água constante na superfície, juntamente com a força ablativa do laser, ajudam na remoção do material ablacionado ${ }^{44}$.

Durante o processo ablativo com laser de alta intensidade de energia, profundas alterações químicas e físicas podem ser induzidas nos tecidos alvo. Por conseqüência o uso da técnica de FTIR é muito útil como uma ferramenta não destrutiva para a análise dos parâmetros ideais do laser aplicados sobre estruturas dentais ${ }^{44}$. 


\subsection{Espectroscopia por FTIR}

A espectroscopia por FTIR é um ensaio não destrutivo para a avaliação das mudanças químicas ocorridas sobre a superfície de tecidos dentais. A vantagem dessa técnica é que a reflectância do tecido analisado é influenciado apenas pela incidência de um feixe sobre a superfície que esta sendo estudada. As alterações superficiais da ordem de $10 \mu \mathrm{m}$ podem ser analisadas por essa técnica. Isto mostra como a analise por FTIR é de fundamental importância também para o estudo de tecidos irradiados com laser ${ }^{45}$.

Em estudo correlacionando a incidência de laser de Er,Cr:YSGG sobre a dentina humana, em diferentes parâmetros de energia, analisou-se a influência sobre as alterações químicas produzidas em cinco elementos químicos (Mg, P, $\mathrm{Ca}, \mathrm{K}$ e Na) por processo de espectrometria de emissão atômica por plasma acoplado indutivamente (ICP- AES). Nos diversos parâmetros de energia aplicados sobre as amostras, houve diferenças entre as proporções dos elementos químicos a exceção do $\mathrm{K}$, que não apresentou alterações significativas nas diversas energias aplicadas ${ }^{46}$.

As alterações térmicas, físicas e químicas do tecido alvo podem influenciar também na qualidade ablativa durante o processo de remoção do tecido alvo, levando a uma diminuição do seu poder de remoção tecidual, com conseqüente aumento da temperatura dos tecidos adjacentes e até a perda da capacidade de remover mais tecido, com os pulsos laser subseqüentes ${ }^{44}$.

\subsection{Redução bacteriana com laser de Er,Cr:YSGG}

A eficácia da redução bacteriana pelo laser de Er,Cr:YSGG foi testada em experimento com 133 raízes dentais humanas infectadas com 
Enterococcos faecalis. Utilizando-se uma ponta de entrega do feixe laser para endodontia tipo Z2 de 320 m de diâmetro (Biolase, San Clemente,CA, EUA), com o display do equipamento em $0,25 \mathrm{~W}$ e taxa de repetição de $20 \mathrm{mHz}$, a energia entregue foi de 3,13 $\mathrm{mJ}$ por pulso (densidade de energia $=9,95 \mathrm{~J} / \mathrm{cm}^{2}$ ), que é considerada muito baixa. Houve o controle preciso de todas a irradiações com power/energy meter. Mantendo-se a mesma energia em todos os grupos consegui-se a desinfecção na profundidade de $0,5 \mathrm{~mm}(500 \mu \mathrm{m})$ da dentina radicular $^{47}$. A profundidade de penetração dos irrigantes usualmente utilizados nos procedimentos endodônticos é da ordem de $100 \mu m^{15}$. Note que o valor de penetração do laser apresentado nesse estudo $(500 \mu \mathrm{m})$ é muito superior aos irrigantes convencionais.

Estudo comparativo da ação bacteriana do laser de Er,Cr:YSGG com hipoclorito de sódio, em canais contaminados com Enterococcos faecalis, mostrou que há efeito bacteriano do laser ${ }^{43}$.

Em avaliação da ação do laser de Er,Cr:YSGG intracanal utilizado-se fibras de emissão radial ou side firing em um estudo com sessenta raízes dentais humanas foi avaliada a capacidade de redução bacteriana de condutos contaminados com duas variedades de microorganismos (Enterococcus faecalis e Escherichia. Coli). Utilizando-se a fibra tipo RFT2 da Waterlase (Biolase, San Clemente, EUA) com diâmetro de $275 \mu \mathrm{m}$, com taxa de repetição de $20 \mathrm{~Hz}$, duas condições de potência média foram testadas $(0,6 \mathrm{~W}=30 \mathrm{~mJ}$ e $0,9 \mathrm{~W}=45 \mathrm{~mJ})$. As irradiações foram calibradas com power/energy meter. Cinco irradiações foram realizadas com movimentos helicoidais de apical para cervical com a fibra em contato com a parede do conduto radicular durante toda a irradiação. $O$ tempo de relaxação térmica foi de 20 segundos entre as 
irradiações. Esta operação de cinco irradiações com os respectivos intervalos é denominada de ciclo. Para haver padronização nas irradiações todos os ciclos de irradiação foram feitos pelo mesmo operador. Para não haver traço químico ou influência nos resultados e assegurar que a eventual desinfecção fosse atribuída ao laser, durante todo o preparo endodôntico a irrigação foi feita com soro fisiológico apenas e não houve nenhuma aplicação final com EDTA. A redução bacteriana para Escherichia. Coli para as duas condições foi satisfatória, para o Enterococcus faecalis a redução para ambas as condições de irradiação produziu redução de 4 log-step em relação ao grupo controle ${ }^{14}$.

\subsection{Pontas de safira de emissão axial}

O uso do laser de Er;Cr:YSGG intracanal exige o uso de pontas de safira com diâmetros compatíveis com o conduto, pois essa pequena fibra deve ser levada até o final do comprimento de trabalho desejado. No sentido de determinar-se o grau de ablação e conseqüente remoção de dentina intracanal radicular um estudo apresentou o resultado de diversas potências com vários diâmetros de fibras de safira axiais e o grau de remoção de tecido intracanal.

Três diferentes diâmetros de fibras foram utilizados neste experimento (200 $\mu \mathrm{m}=Z 2 ; 320 \mu \mathrm{m}=Z 3 ; 400 \mu \mathrm{m}=Z 4$ da Waterlase (Biolase, San Clemente, EUA) e com o comprimento das fibras também diferentes $(9 \mathrm{~mm}, 14 \mathrm{~mm}, 18$ $\mathrm{mm}, 20 \mathrm{~mm}, 22 \mathrm{~mm}$ e $25 \mathrm{~mm}$ ). O resultado medido foi o do volume de dentina removido em cada ensaio, o que se aproxima da situação clinica pois um canal radicular é tridimensional. Os resultados demonstraram que para as três potências médias testadas ( $1,5 \mathrm{~W}, 1,75 \mathrm{~W}$ e $2 \mathrm{~W}$ ) os aumentos no diâmetro da fibra associados ao aumento de potência média resultam em maior volume de dentina removido de dentro dos canais ${ }^{48}$. 
Outro fator de grande importância na utilização das fibras do tipo axiais é a angulação da fibra dentro do canal radicular e o modo de emissão do feixe, que neste caso é paralelo ao longo eixo do dente, pois estes fatores são mais decisivos do que 0 diâmetro em $\mathrm{si}^{48}$, pois dessa maneira o feixe será direcionado para as paredes dentinárias aumentando seu poder ablativo.

\subsection{Pontas de emissão radial (side firing)}

As características positivas, já estabelecidas do uso do laser de Er;Cr:YSGG em Odontologia, podem ter suas características melhoradas com o uso de fibras com emissão lateral, ou grande.grande abertura numérica. Essa melhora pode ser obtida em processos de descontaminação tanto em bolsas periodontais quanto em uso intracanal. As fibras ópticas de uso em endodontia necessitam ser pequenas e flexíveis para poderem estar em contato constante e acompanhar a curvatura complexa e tortuosa dos condutos radiculares. As fibras (ou pontas de entrega de feixe) de emissão axial proporcionam uma pequena divergência para o feixe (baixa abertura numérica). Para que o feixe atue de maneira adequada nas paredes do conduto, as pontas precisam fazer contato por pressão contra as mesmas, rotacionadas em movimentos repetidos e retirada várias vezes ${ }^{49}$.

Estudou-se vários perfis de emissão de energia lateralmente ao longo eixo da fibra de maneira a otimizar a sua emissão, aumentando a energia entregue ao tecido e com isto tornar essa técnica útil à Odontologia ${ }^{49}$. O melhor efeito ablativo pode ser conseguido com esse tipo de fibra uma vez que, anatomicamente a direção dos túbulos está perpendicular ao longo eixo da luz do conduto radicular. Então uma fibra que percorre o conduto radicular 
emitindo seu feixe laser radialmente, emitirá seu feixe no longo eixo dos túbulos dentinários.

Devido à reflectância total nas laterais das fibras, o feixe laser ao emergir de uma fibra axial, apresenta pouca divergência. $O$ feixe laser neste caso como está direcionado ao ápice, concentrando quase toda sua energia nessa direção. O movimento em espiral da fibra no interior do conduto e a inclinação da mesma no movimento de irradiação, é uma forma do profissional compensar de certa maneira, o fato da maior quantidade de energia estar sendo direcionada apicalmente e com isso conseguir-se irradiar as paredes do conduto $^{14}$, mesmo que parcialmente.

As fibras de emissão lateral (side firing - RFT2 de $275 \mu \mathrm{m}$ de diâmetro e RFT3 de $415 \mu \mathrm{m}$ de diâmetro da Waterlase [Biolase, San Clemente, EUA]) emitem o feixe com uma divergência de $60^{\circ}$, o que co rresponde a uma abertura numérica aproximada de 0,86 . Desta forma faz-se com que o feixe laser seja emitido com uma abertura maior obtendo-se a expansão do feixe e dessa maneira aumentar a área de atuação no conduto ${ }^{14}$, além de direcionar o feixe ao longo dos túbulos.

\subsection{Remoção do smear layer com laser de Er;Cr:YSGG}

O laser de Er,Cr:YSGG altera a superfície dentinária e dependendo dos parâmetros utilizados, causa a limpeza e remoção do smear layer ${ }^{50}$.

Em uma comparação entre as superfícies dentinárias irradias com laser de Er;Cr:YSGG (125mJ; $20 \mathrm{~Hz})$ e cortadas com instrumentos rotatórios diamantados em alta rotação e analisadas com MEV, constatou-se que as superfícies irradiadas ficaram completamente limpas e livres de smear layer para os parâmetros de energia utilizados ${ }^{40}$. 
A comparação do uso do laser de Er;Cr:YSGG e clorehexidina foram feitas no sentido de avaliarem o efeito sobre a dentina com o uso de dois tipos diferentes de sistema adesivos. Em ambas as condições obtiveram-se melhoria da adesão em relação ao controle ${ }^{51}$.

Irradiação em dentina radicular com parâmetros de energia de 3,13 J por pulso em $20 \mathrm{~Hz}$ e densidade de energia de calculada para uma fibra de $200 \mu \mathrm{m}$, de $9,95 \mathrm{~J} / \mathrm{cm}^{2}$ apresentou sinais de ablação dentinária deixando os túbulos expostos. Não havia sinais de carbonização ou fusão da superfície tratada com

- laser. Em diversos aumentos das micrografias a superfície dentinária apresentou-se livre de smear layer ou outros detritos ${ }^{47}$.

Com a utilização de fibra RTF2 e dois parâmetros de energia 30 mJ e 45 mJ por pulso, em $20 \mathrm{~Hz}$, irradiado intracanal após os mesmos terem sido tratados endodonticamente e avaliados em MEV, mostraram nos dois parâmetros de irradiação a remoção de completa do smear layer. Esse tipo de fibra possui uma grande abertura numérica que causa uma irradiação mais uniforme nas paredes do conduto, explicando a melhor remoção dos resíduos intracanal obtida ${ }^{14}$.

\subsection{Adesão à dentina radicular.}

Em linhas gerais três técnicas diferentes de cimentação adesiva resinosa podem ser utilizadas para a fixação de núcleos em condutos radiculares:

\subsubsection{Total-etching (etch and rinse)}

A técnica de condicionamento total da superfície dentinária com ácido pressupõe o uso concomitante com um adesivo, para a posterior 
utilização de um cimento resinoso. Esse adesivo representa uma interface de união, entre a dentina e o cimento. Os adesivos são uma mistura de monômeros resinosos hidrofílicos com hidrofóbicos, produzindo um composto anfifílico. Esse composto tem a finalidade de aderir-se a parede dentinária que é úmida com os compostos resinosos que são tipicamente hidrofóbicos. Os monômeros dos adesivos podem estar dissolvidos em solventes como água, acetona ou etanol ${ }^{26}$.

\subsubsection{Self-etching}

No sistema adesivo tipo self-etching os constituintes do smear layer podem fazer parte do substrato adesivo. O primer deste sistema é ácido o suficiente para desmineralizar quase a totalidade do smear layer e a camada subjacente de dentina. À medida que corroem também cobrem o colágeno exposto com monômeros hidrofílicos, que co-polimerizará com a subseqüente resina.

O conceito de um primer ácido é muito interessante por representar uma simplificação de técnica, pois o mesmo produto, simultaneamente, descalcifica os componentes inorgânicos e interage com a matriz de colágeno. Esta técnica minimiza a exposição de colágeno da interface dentina-adesivo $0^{52}$.

\subsubsection{Self-adhesive}

Os cimentos do tipo self-adhesive são uma categoria relativamente nova de material. Foi introduzida comercialmente no mercado no ano de 2002, sendo o primeiro produto comercial o RelyX Unicem Aplicap da 
3M (ESPE, St.Paul, MN,EUA). Até o presente momento há relativamente pouca literatura sobre a composição e suas características mecânicas, ou até uma comparação entre os diferentes produtos comercializados.

O intuito de atribuir a este material como uma nova classe de material é por esse ser de fácil manuseio e apresentar vantagens sobre outras categorias de cimentos. Ele não requerer nenhum tratamento prévio ao conduto em que se fixará um núcleo, não requer a remoção do smear layer, é de passo único, tolera a umidade e libera íons flúor ${ }^{53}$.

A preocupação de um profissional ao recuperar um elemento dental deve levar em consideração a avaliação da estrutura dental remanescente e sua relação com a adesividade aos materiais que serão utilizados. Há uma grande quantidade de variáveis envolvidas em todo o processo. Por exemplo, o protocolo utilizado para a endodontia, os irrigantes utilizados, o cimento obturador, o tempo do término do tratamento e etc., pois estas variáveis afetam diretamente a dentina e em extensão a adesividade ${ }^{1}$.

O tratamento endodôntico deve ser finalizado primeiro, para então providenciar-se a remoção da guta percha e do cimento obturador endodôntico e posterior colocação de núcleo. Essa seqüência ficou estabelecida por estudo com 120 raízes dentais unirradiculares humanas. Provou-se que com essa seqüência aumenta-se significativamente a adesão em relação a qualquer outra combinação proposta ${ }^{54}$.

Há também a influencia no tempo para a cimentação do núcleo em relação ao término do tratamento endodôntico. A melhor adesão de um núcleo 
em resina reforçada em conjunto com cimentado resinoso, é após 24 horas o término da endodontia finalizada ${ }^{16}$.

A adesão à dentina radicular de núcleos de fibra de vidro reforçados (ou qualquer tipo de núcleo) representa um desafio. A forma elipsoidal do conduto, e as estruturas morfológicas, principalmente nas porções mais próximas ao ápice dental, não favorecem a adesão. As diferenças anatômicas e disposição das fibras de colágeno podem explicar as diferenças na qualidade de adesão nos diferentes terços radiculares ${ }^{7}$.

Outros fatores que se somam na dificuldade de se estabelecer uma adesividade adequada no conduto radicular são a dificuldade de aceso ao canal radicular, sua visualização adequada e o controle de umidade que os adesivos do tipo total-etching e self-etching impõem.

O fator $\mathrm{C}$, que é o quociente entre a área aderida pela área não aderida $^{55}$, em casos de núcleos é desfavorável. Nos casos de fator $\mathrm{C}$ elevado (caso dos núcleos), materiais resinosos que apresentarem uma presa mais lenta são mais adequados, por apresentarem menor tendência à fratura espontânea. As fraturas da resina que ocorrem dentro do canal radicular se dão pelo fato do estresse de contração ser maior do que a resistência de união adesiva da dentina com o cimento ${ }^{56}$

Em procedimentos adesivos com laser de alta potencia em estruturas dentais irradiadas, a dentina se constitui em um grande desafio, onde um fator de grande importância é a sua complexa matriz de colágeno do seu substrato. A matriz colágena constitui-se em média a $50 \%$ do volume da dentina, o que leva ao extremo cuidado que temos que ter ao irradiar-se a dentina com laser de alta potência. Dependendo do gradiente térmico atingido pelo tecido alvo e o 
tecido adjacente a área irradiada, poderemos causar efeitos deletérios sobre a matriz de colágeno, alterando suas características, modificando também a qualidade da adesão ${ }^{57}$.

A eficácia da adesão no uso de materiais restauradores adesivos tanto no aspecto da aderência em si ou na resposta pulpar (em caso de dentes com polpa) frente a procedimentos restauradores adesivos é fundamentalmente dependente da estrutura da dentina na região em que se está executando o procedimento. O conhecimento da densidade de túbulos, tamanho e complexidade de anastomoses nas diferentes regiões se faz necessário ${ }^{19}$. A resistência de união adesiva em dentina humana varia em função da região dental, sendo que a resistência de união adesiva em camadas mais profundas é menor ${ }^{25}$.

A influência da localização em cada terço dental com o aumento da quantidade de túbulos dentinários abertos, após condicionamento com ácido fosfórico da superfície dentinária intracanal radicular, foi determinada por estudo que comparou mais de trinta raízes dentais humanas. Os valores obtidos foram percentualmente, $202 \%$ para o terço cervical, $156 \%$ para o terço médio e $113 \%$ para o apical de túbulos aberto em relação à superfície sem condicionamento ácido ${ }^{23}$.

Os adesivos usam a técnica do total-etching apresentam uma maior micro-permeabilidade, e em casos onde são aplicados em dentes com vitalidade pulpar, são afetados pela pressão hidrostática pulpar. Isto ocorre pela remoção promovida pelo ácido fosfórico da dentina peritubular e eliminação do smear layer ${ }^{58}$. 
A penetração do agente adesivo na dentina é crucial para uma união com a dentina. A remoção do smear layer permite a infiltração da resina tanto nos túbulos como na região intertubular. A penetração da resina dentro dos túbulos dentinários permite o selamento adequado e assim contribuir para 0 aumento da força de união com a dentina ${ }^{30}$.

O adesivo do sistema de self-etching produz uma reação com a camada de smear layer não causando a sua remoção, mas selando-a ${ }^{58}$. A resistência de união adesiva nesse sistema é significativamente afetado pela orientação dos túbulos dentinários e pelo $\mathrm{pH}$ do meio ${ }^{59}$.

Utilizando-se diversos produtos para limpeza da cavidade protética para colocação de núcleos em fibra de vidro reforçado antes da cimentação, analisou-se a influencia destes agentes na resistência de união adesiva. Foi utilizado em todos os grupos o cimento dual, com adesivo tipo self-etching (Panavia F, Kuraray Medical, Okayama, Japão). O grupo que apresentou 0 melhor resultado, foi o que também possuía maior quantidade remanescente de smear layer ${ }^{60}$.

A influência das diferenças da densidade dos túbulos dentinários nas diversas partes da raiz dental e a adesão para o sistema total-etching, mostrou uma correlação direta da densidade com a espessura da camada híbrida. A espessura da camada híbrida é dependente da densidade dos túbulos na medida em que a menor quantidade de túbulos apresenta uma cama híbrida menor e vice-versa ${ }^{23}$.

Em estudo para determinação da importância da utilização do cimento resinoso adesivo para a fixação de núcleos em fibra de vidro reforçado comparou-se ao uso do cimento de fosfato de zinco, submetidos a ensaio de 
ciclagem térmica (6000 ciclos de $5^{\circ} / 55^{\circ} \mathrm{C}$ a cada 2 minutos) e $1,2 \times 10^{6}$ ciclos mastigatórios com $50 \mathrm{~N}$, a $135^{\circ}$ de inclinação. Nas quarenta amostras ensaiadas mostrou superioridade os grupos cimentados com cimento resinoso do tipo self-adhesive ${ }^{61}$.

São observadas reduções significativas na resistência de união adesiva entre os cimentos adesivos e os núcleos, para sistemas adesivos (self-etching e total-etching) nas porções radiculares localizadas mais apicalmente ${ }^{56}$.

\subsection{Ensaio mecânico: Teste de push-out}

O ensaio mecânico tem a finalidade de dar um parâmetro numérico para a avaliação dos resultados obtidos nos experimentos, no caso deste estudo, para avaliar a adesividade. Valores obtidos pela força de deslocamento, cisalhamento, tração e etc., são mensuráveis e conseqüentemente comparáveis.

Diversas nomenclaturas e variações de técnicas são encontradas em literatura para o teste de push-out (push-out de finas fatias, push-out de discos, micro push-out e etc.). Do ponto de vista mecânico é um ensaio de compressão para verificação da resistência de união adesiva até o ponto de fratura. Neste caso os corpos de prova são finas fatias do conjunto raiz dental e núcleo cimentado ${ }^{62}$. Esse teste é adequado para o ensaio da força de tração entre núcleos de fibra de vidro reforçada e cimentos resinosos ${ }^{63}$.

No caso de núcleos cimentados com materiais resinosos, o ensaio conhecido como push-out, ou compressão do núcleo (ou uma secção do mesmo) é um método aceitável, dentre outros métodos de ensaio, apresentando uma variabilidade de dados compatível. Ainda podem-se avaliar diferenças regionais nos diferentes terços do núcleo ${ }^{64}$. 
Neste teste os corpos de prova são colocados em uma maquina de ensaio universal e aplica-se uma força sobre a secção do pino. A estrutura dental deve estar apoiada e a ponta que executa a punção deve ter diâmetro menor do que o diâmetro que está sendo ensaiado ${ }^{65}$. A força é aplicada no sentido de deslocamento de núcleo ensaiado e anota-se a força máxima de deslocamento. A velocidade de aplicação da força sobre a amostra está estabelecida em $0,5 \mathrm{~mm} /$ minuto $^{50}$.

Em ensaios de compressão (push-out) comparativos de cimentos adesivos de três tipos diferentes de ação (self-etching=> Panavia 21EX e Clearfill esthetic; total-etching $=>$ Variolink II e self-adhesive $=>$ RelyX Unicem Aplicap e GC experimental) com núcleos de fibra de vidro, os grupos em que os cimentos que utilizaram um adesivo tipo self-etching apresentaram o melhor resultado. Neste estudo não houve nenhum tratamento prévio sobre a superfície do núcleo que era de forma cilíndrica. No conduto utilizou-se apenas $2 \mathrm{ml}$ de $\mathrm{NaOCl}$ para limpeza, após o preparo para instalação dos núcleos ${ }^{66}$.

Em outro estudo comparativo entre três sistemas adesivos (total-etching, self-etching e self-adhesive) utilizados para a cimentação de núcleos em resina de vidro reforçada em 42 raízes dentais humanas, contrariamente, demonstrou que o sistema self-etching (Panavia F, Kuraray Medical, Okayama, Japão) apresentou o pior comportamento em relação aos outros sistemas. O método de ensaio foi push-out de discos de $1 \mathrm{~mm}$ de espessura, onde se calculou área de adesão pela força máxima de compressão. O grupo cimentado com 0 sistema total-etching da Calibra resin cement, XP Bond adhesive/self-curing activator (SCA), RadiX Fiber Post (Dentsply Caulk, Milford, DE, EUA) e o grupo cimentado com RelyX Unicem Aplicap e RelyX Fiber Post (3M ESPE, Seefeld, 
Alemanha) apresentaram resultados estatisticamente superiores aos demais grupos estudados ${ }^{67}$. Em outro estudo também comparando os três sistemas (total-etching, self-etching e self-adhesive), o grupo de pior resultado para o ensaio de push-out foi 0 do tipo total-etching. O sistema self-adhesive apresentou resultados superiores em termos de força adesiva, mas apresentava uma camada híbrida muito irregular, com menor profundidade de penetração nos túbulos e em menor quantidade do que outros grupos ${ }^{68}$.

A literatura até este ponto, não estabelece critérios definitivos e claros sobre os parâmetros críticos que possam ser seguidos para uma perfeita adesão dos núcleos. Este fato reforça a necessidade e importância de estudos in vitro que visem o estabelecimento de protocolos, analise da qualidade de adesão, longevidade e estabilidade para que sirvam de princípios sólidos para utilização na clinica protética. 


\section{DESENVOLVIMENTO EXPERIMENTAL}

Para a apresentação do desenvolvimento deste trabalho foi feita uma divisão em três tópicos. Será apresentada para cada etapa a metodologia e seus resultados, permitindo expressar o desenvolvimento experimental com maior clareza.
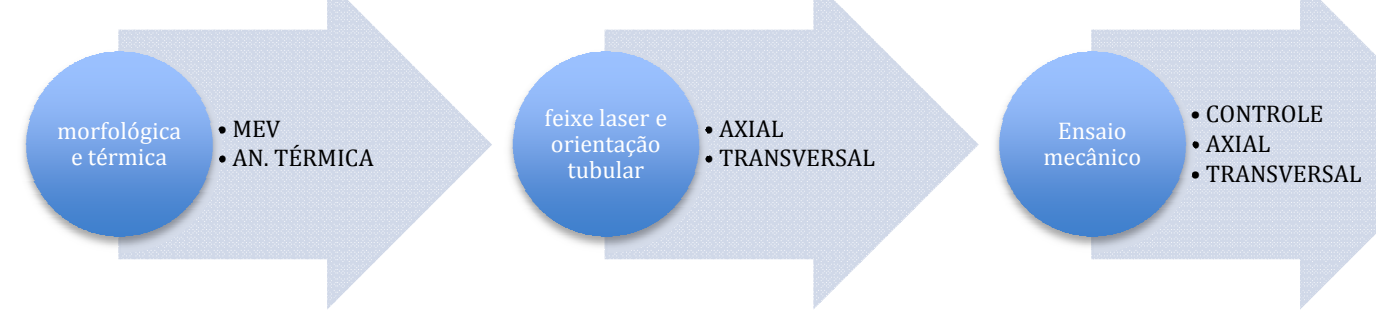

Figura 1: Esquema da seqüência experimental do estudo.

Todos os dentes utilizados neste experimento são provenientes do banco de dentes da Faculdade de Odontologia da Universidade de São Paulo, obtidos após aprovação pelo Comitê de Ética em Pesquisa em Seres Humanos, da mesma instituição (protocolo 177/2010; CAAE: 0006.0.017.00010), humanos, unirradiculares, anteriores, sem nenhum tipo de calcificação, dilaceração, ou tratamento endodôntico prévio. Eles ficaram armazenados em água destilada e foram mantidos sob refrigeração durante todas as fases do experimento, conforme norma ISO/TS 11405, para estudos em teste de adesão à estrutura dental ${ }^{69}$. 


\section{ANÁLISE TÉRMICA E MORFOLÓGICA}

A primeira etapa deste estudo foi determinar parâmetros adequados para irradiação laser. Há muita discrepância entre os trabalhos publicados sobre irradiação com laser de Er, Cr: YSGG em canais radiculares ${ }^{70,71}$. Há um limite seguro conhecido de temperatura máxima, que a porção externa da raiz pode atingir ${ }^{72}$, acima dos quais haveria efeitos biológicos indesejáveis, tornando o seu uso clínico inviável. Por essa razão diferentes energias foram testadas.

\subsection{Material e Métodos}

\subsubsection{Preparo dos espécimes para tratamento endodôntico inicial}

As raízes foram separadas da coroa na junção amelo-cementaria radicular, na altura das faces proximais. $O$ corte foi realizado em uma cortadeira de alta precisão (Accutom 5- Struers, Cleveland, OH, EUA) com disco diamantado de dupla face de corte nas dimensões de 76 × 0,15 mm (HD Struers, Cleveland, OH, EUA), com refrigeração abundante de água.

Para o tratamento endodôntico dos condutos radiculares foi usada instrumentação mecânica com sistema de instrumentos rotatórios de níqueltitânio (Protaper; Dentisply/Maillefer ,Ballalgues, Suíça) e técnica de preparo preconizada pelo fabricante, a $1 \mathrm{~mm}$ do forame apical com alargamento do conduto até o número $30^{73}$. O preparo apical final foi realizado com lima manual.

O preparo químico-mecânico foi irrigado com solução de hipoclorito de sódio a 2,5\% em cada troca de instrumento, com irrigação final com 
clorhexidina a $2 \%$. Ao final do processo o conduto foi seco com cones de papel estéril. Não houve selamento endodôntico e os espécimes acondicionados em ambiente úmido e refrigerados a $5^{\circ} \mathrm{C}$.

\subsubsection{Formação dos grupos de estudo}

Após tratamento endodôntico vinte e sete espécimes foram divididos em nove grupos aleatórios com 3 raízes cada. Um grupo foi usado como controle e oito grupos irradiados, variando seus valores de potência média de 0,25 a $2,00 \mathrm{~W}$, correspondendo a energias de pulso entre $12,5 \mathrm{~J}$ a $100 \mathrm{~mJ}$, com intervalos de 0,25 W, com 34\% de ar e $24 \%$ de água (Tabela 1).

\subsubsection{Irradiação laser}

As superfícies dentinárias dos condutos intra-radiculares foram irradiadas em contacto, com uma ponta de safira para entrega de feixe intracanal radicular com $200 \mu \mathrm{m}$ de diâmetro, modelo Z2 da Waterlase ${ }^{\star i}$ (Biolase, San Clemente, CA, EUA) com fator de transmissão nominal de 0,3 e taxa de repetição em $20 \mathrm{~Hz}$.

A energia de saída foi monitorada antes de cada irradiação utilizando-se um power/energy meter (FieldMaster GS, Coherent Inc., Santa Clara, CA, EUA) com o sensor LM 10P, do mesmo fabricante (Figura 2). O valor de energia radiante foi calculado, considerando-se a área efetiva do feixe na região de incidência, que é a posição na qual o feixe cai a $1 / \mathrm{e}^{2}$ da sua intensidade. Para facilitar a medição da energia foi colocado um espaçador entre a peça de mão do laser e o sensor. Este recurso facilitou a aferição de cada irradiação além de uniformizar o procedimento. A aferição foi executada antes da irradiação em cada raiz.

${ }^{i}$ Projeto CEPOF-FAPESP , processo CEPID 05/51689-2 
O tempo total de irradiação no interior do conduto foi proporcional à metade do comprimento dos canais. A velocidade de irradiação ápico-cervical, foi de $2 \mathrm{~mm} / \mathrm{s}$. e o intervalo entre as radiações para assegurar a relaxação térmica foi de 20 segundos. Cada ciclo compreendeu cinco repetições. Para cálculo de densidade de energia, assumiu-se o diâmetro efetivo do feixe (1 $\left.1 / \mathrm{e}^{2}\right) \times 200 \mu \mathrm{m}$, para fibra Z2, conforme dados da Tabela 1 .

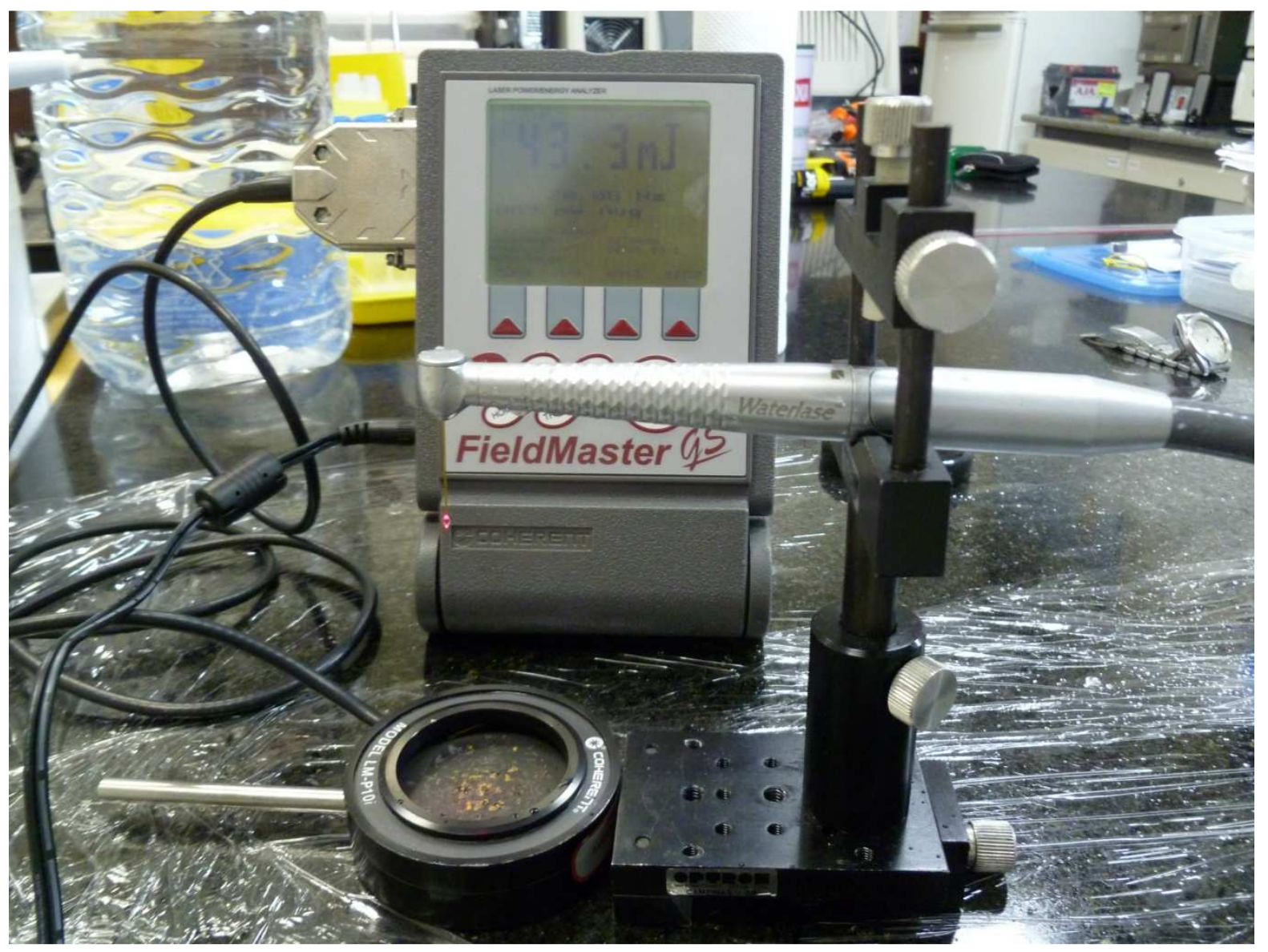

Figura 2: Aferição do pulso de energia laser em cada irradiação. Note aparato para padronização inclusive da distancia do feixe 
Tabela 1- Densidades de energia entregue às amostras.

\begin{tabular}{ccc}
$\begin{array}{c}\text { Potência média no } \\
\text { display [W] }\end{array}$ & $\begin{array}{c}\text { Energia medida } \\
\text { [mJ] }\end{array}$ & $\begin{array}{c}\text { Densidade de energia } \\
\text { calculada }\left[\mathbf{J} / \mathbf{c m}^{\mathbf{2}} \text { ] }\right.\end{array}$ \\
\hline $\mathbf{0 , 2 5}$ & 3,75 & 15,95 \\
$\mathbf{0 , 5 0}$ & 7,50 & 31,91 \\
$\mathbf{0 , 7 5}$ & 11,25 & 47,86 \\
$\mathbf{1 , 0 0}$ & 15,00 & 63,81 \\
$\mathbf{1 , 2 5}$ & 18,75 & 79,76 \\
$\mathbf{1 , 5 0}$ & 22,50 & 95,72 \\
$\mathbf{1 , 7 5}$ & 26,50 & 111,67 \\
$\mathbf{2 , 0 0}$ & 30,00 & 127,63 \\
\hline
\end{tabular}

\subsubsection{Avaliação térmica}

O monitoramento da temperatura foi feito por uma câmara termográfica*ii (Thermocam SC 3000, FLIR Systems, Boston, MA, EUA) de resposta rápida e alta resolução $\left(0,01 \mathrm{~s}\right.$ e $\left.0,001{ }^{\circ} \mathrm{C}\right)$. O ambiente de medidas teve a umidade relativa monitorada em $72 \%$ e temperatura ambiente estável e controlada em $20^{\circ} \mathrm{C}$, uma hora antes e durante todo o experimento ${ }^{74}$.

\subsubsection{Analise morfológica por Microscopia Eletrônica de Varredura}

Os aspectos morfológicos das paredes do canal radicular foram analisados com auxílio de microscopia eletrônica de varredura de alto vácuo.

Após a irradiação foram executadas fraturas guiadas das raízes, longitudinalmente, dividindo a raiz em duas metades, para análise das superfícies.

As amostras passaram pelo seguinte protocolo de preparo:

\footnotetext{
ii Projeto CEPOF-FAPESP , processo CEPID 98/14270-8
} 
- Fixação com glutaraldeido a 2,5\% tampão fosfato de sódio $0,1 \mathrm{M}$;

- Três lavagens sucessivas com água destilada ( $3 \times 10$ minutos);

- Pós-fixação com tetróxido de ósmio a $1 \%$ (20 minutos);

- Lavagem com tampão fosfato de sódio $0,1 \mathrm{M}$;

- Desidratação dos dentes com série crescente de alcoóis (50\% a 100\%);

- Secagem com hexametildisilazane (HMDS);

- Fixação dos dentes nos suportes metálicos;

- Metalização com filme fino de ouro.

\subsection{Resultados}

\subsubsection{Avaliação térmica}

Os dados foram analisados pelo programa Thermacan Researcher (FLIR Systems, Boston, MA, EUA) para avaliação das temperaturas máximas atingidas nas regiões apical, média e cervical (Figura 3).

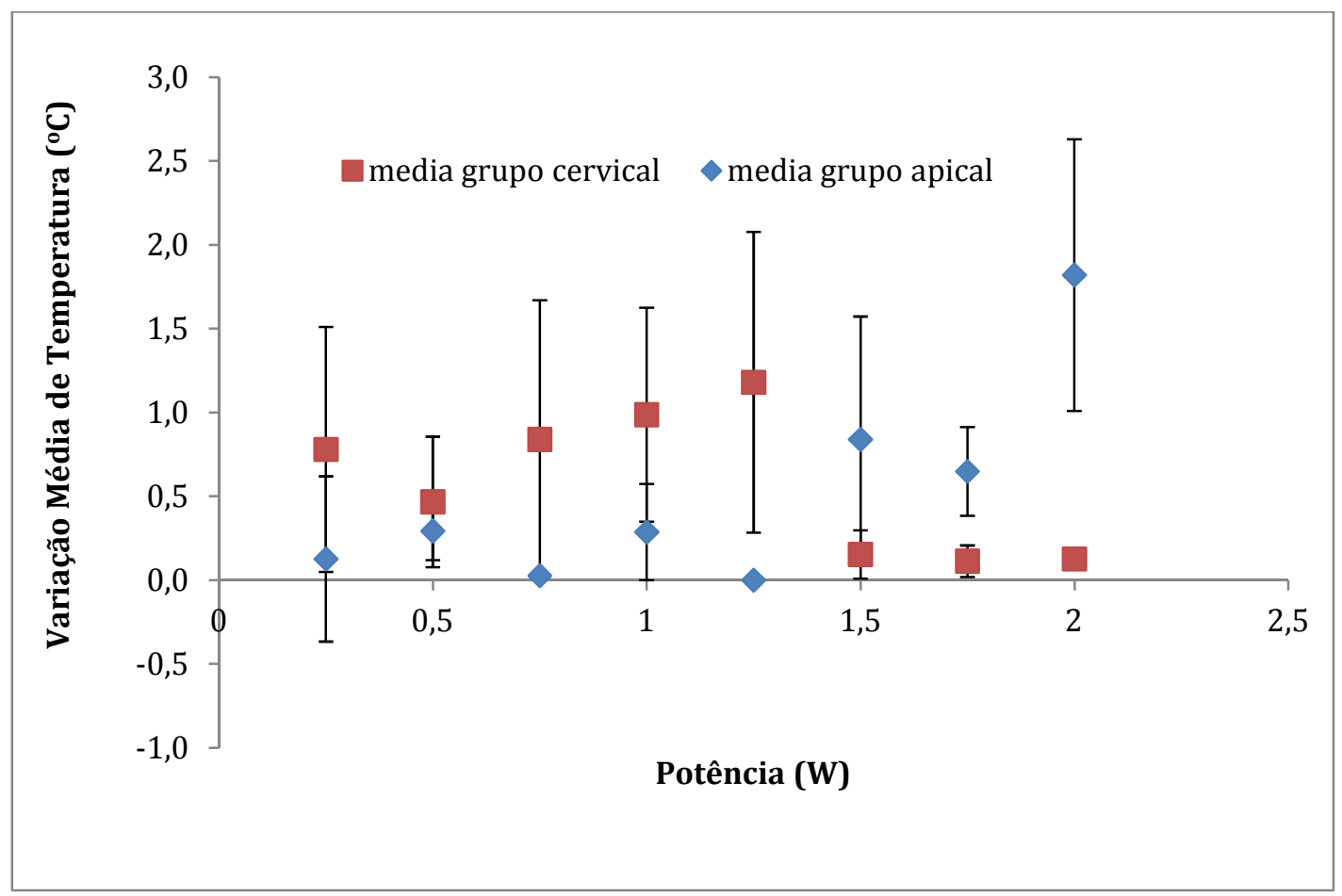

Figura 3-Temperaturas médias e erro padrão nas posições (cervical e apical)*. * [Note que a refrigeração durante a irradiação não levou a aumentos médios de temperatura maiores que $2^{\circ} \mathrm{C}$, nas potências médias utilizadas.]

\subsubsection{Morfológicos:}




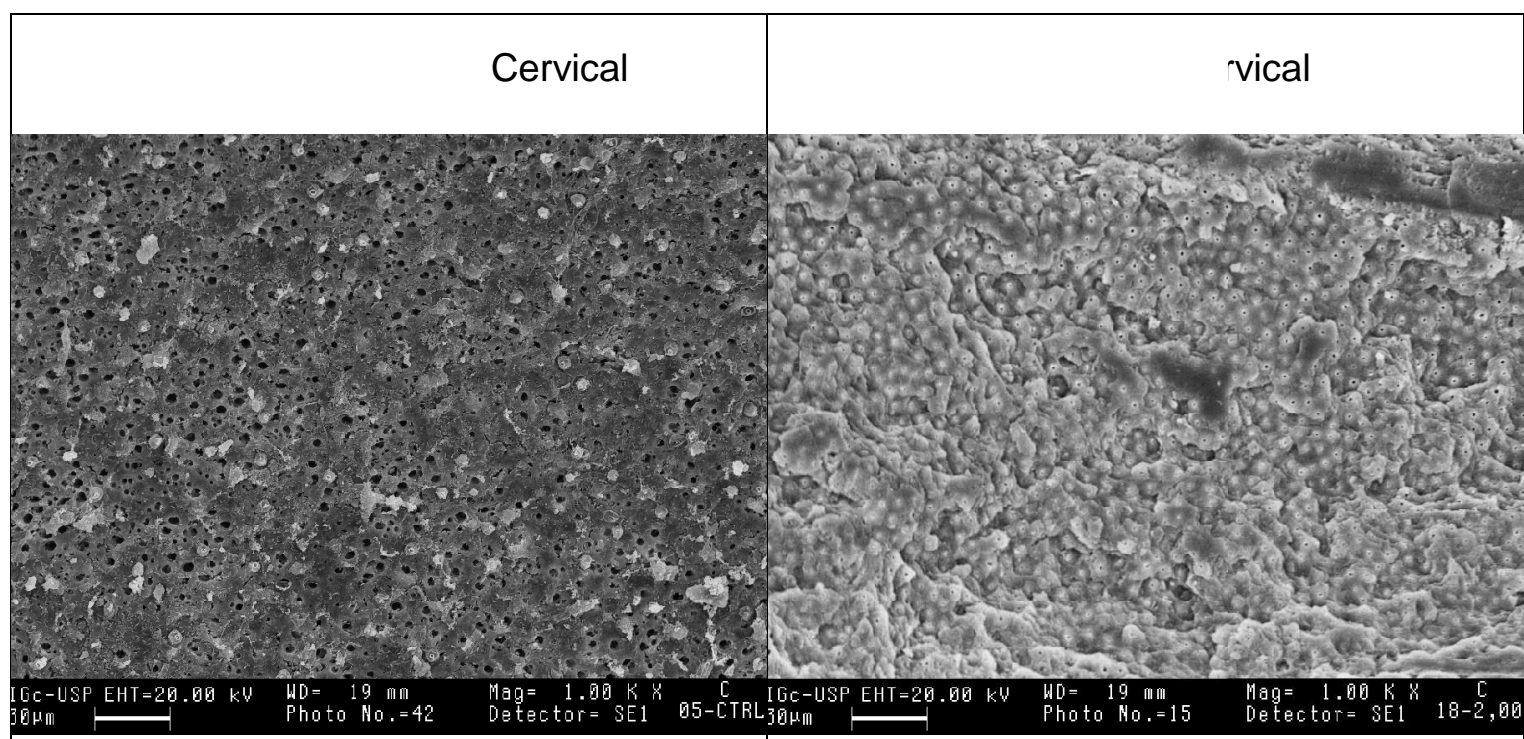

\begin{tabular}{|c|c|}
\hline & \\
\hline édio & édio
\end{tabular}
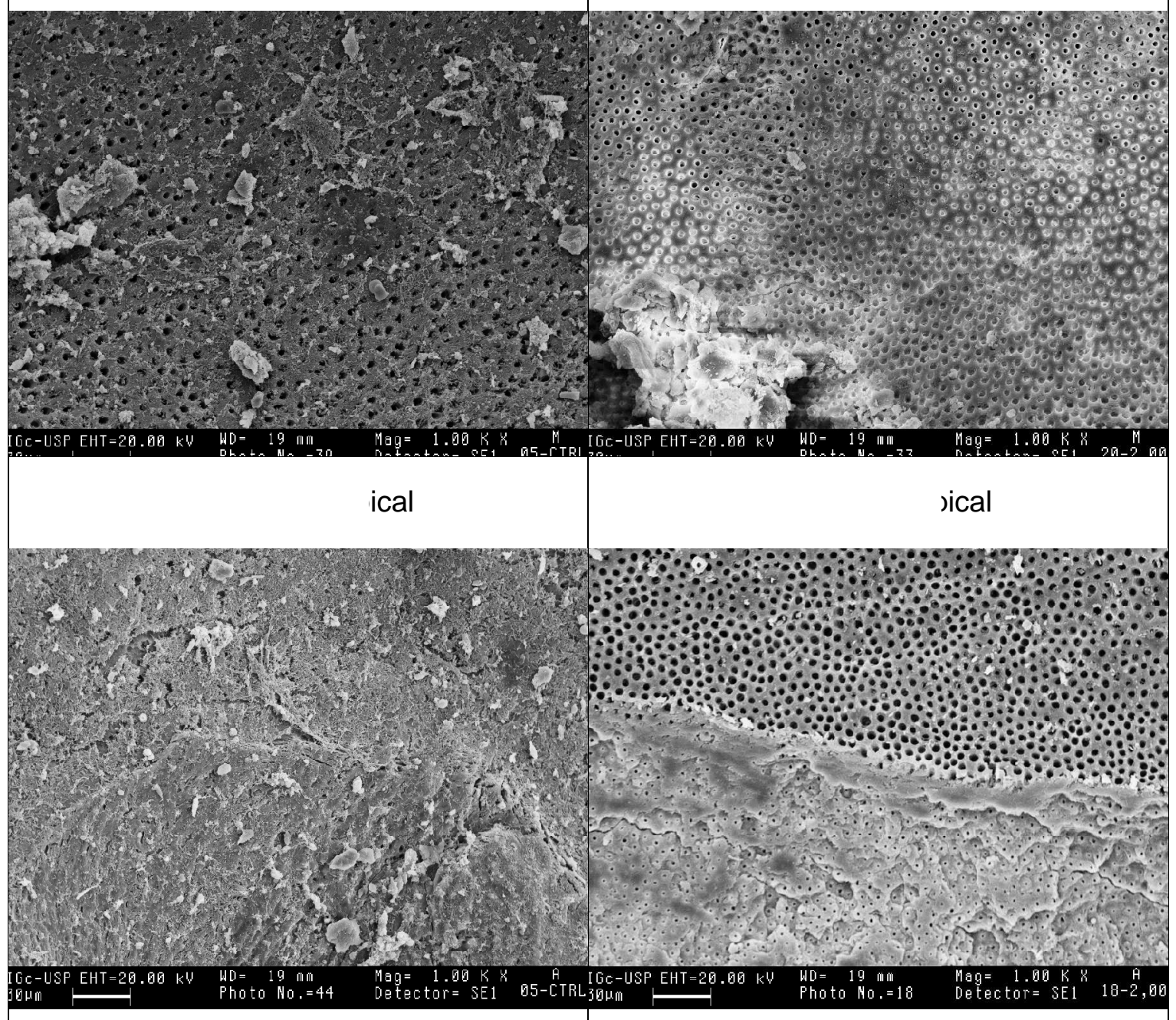

Figura 4:Micrografias eletrônicas das paredes dos túbulos. No grupo controle (A,B e C) é verificada grande quantidade de resíduos. Irradiação em altas densidades, acima de $128 \mathrm{~J} / \mathrm{cm}^{2}$, causou fusão da superfície (E,F e G). Imagens: Quinto Jr. et al ${ }^{75}$ 

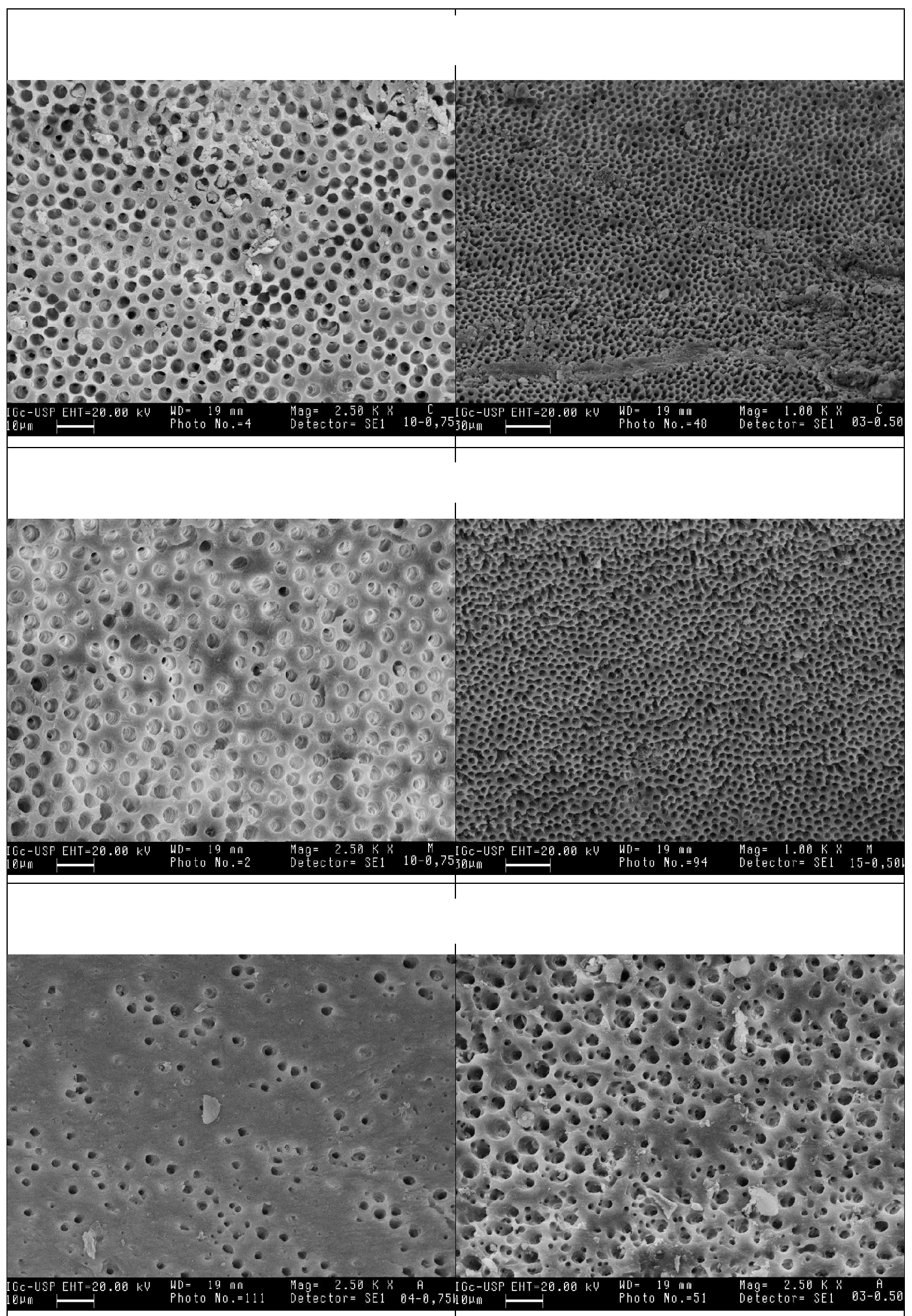

Figura 5: Grupos irradiados com densidades de energia entre 32 a $49 \mathrm{~J} / \mathrm{cm}^{2}$ apresentaram superfície mais livres de smear layer e maior quantidade de túbulos abertos. Imagens: Quinto Jr. et al. ${ }^{75}$ 
Foram executadas avaliações em três sítios diferentes em cada amostra, em uma das metades. Os campos observados e analisados (Figura 4 e Figura 5) foram escolhidos de maneira padronizada, em pontos prédeterminados em três distâncias fixas em relação ao ápice: $2 \mathrm{~mm}$ (apical); 6 mm (média) e 9 mm (cervical).

As eletromicrografias foram analisadas com mesma ampliação. Padronizou-se o aumento original (1000 e 2500 vezes) e a resultante barra dimensional em $30 \mu \mathrm{m}$ e $10 \mu \mathrm{m}$. Realizou-se a contagem dos túbulos dentinários nas imagens padronizadas.

Essa contagem foi realizada do software livre Image $\mathrm{J}(\mathrm{NIH}$, Bethesda, $\mathrm{ML}$, EUA), onde padronizou-se também a área para contagem. Três avaliadores calibrados anotaram numericamente a quantidade de túbulos totalmente obstruídos, parcialmente obstruídos e totalmente abertos.

O histograma (Figura 6) com os dados adquiridos para a análise quantitativa e permitiu avaliar numericamente a eficácia dos parâmetros de irradiação. 

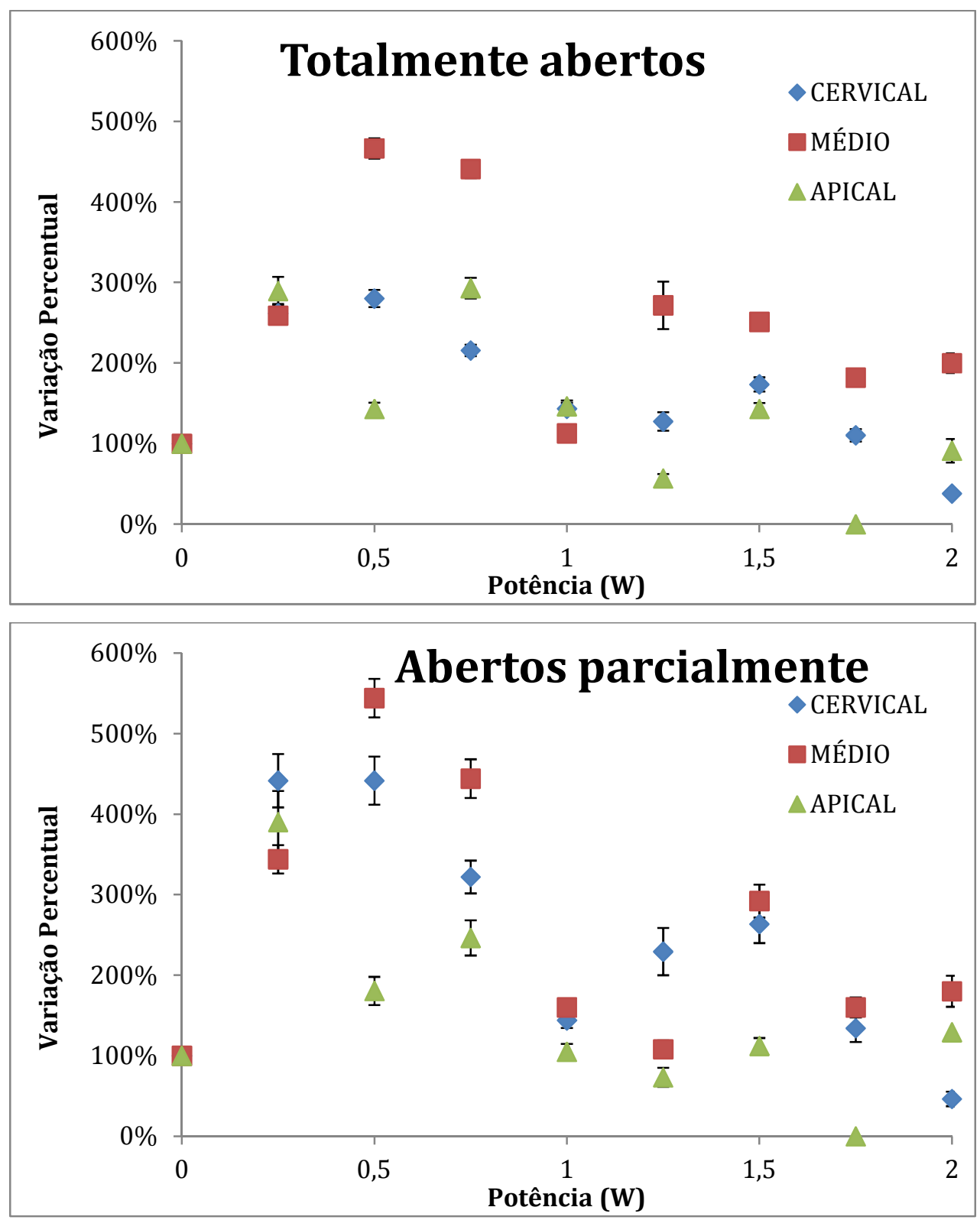

Figura 6: Distribuição da quantidade de túbulos abertos em função da potencia média de irradiação e da região 


\section{ANÁLISE POR FTIR (influência do eixo de orientação do feixe laser $\mathrm{x}$ túbulos)}

As paredes do conduto radicular apresentam os túbulos voltados para a luz do canal, o que significa ter o eixo de orientação perpendicular ao mesmo. Para irradiação laser intracanal as fibras endodônticas Z2, Z3 e Z4 (Biolase, San Clemente, CA, EUA) têm emissão do feixe ao longo da fibra ou emissão axial, onde o feixe laser também está perpendicular aos túbulos dentinários. Essas fibras também apresentam baixa abertura numérica.

A propagação da luz dentro da dentina é dependente da orientação dos túbulos onde há a amplificação do mesmo ${ }^{36,37,38}$. Até o presente momento, não foi encontrado na literatura nenhum estudo que demonstrasse o efeito físico na dentina ou sobre as implicações nas alterações físico-químicas decorrentes da irradiação laser, referentes a diferenças entre a direção da propagação do feixe laser e os túbulos dentinários.

Este estudo se propôs a avaliar por meio de espectroscopia de absorção no infravermelho por transformada de Fourier (FTIR) a influência do feixe orientado no mesmo sentido dos túbulos e perpendicular aos mesmos. Também foi avaliada a implicação nas diferentes porções do conduto, pois estes apresentam diferenças de densidade de túbulos por área e região, assim como há diferenças entre as densidade ópticas na dentina intertubular $(n=1,45)$, peritubular $(n=1,65)$ e solução intertubular $(n=1,33)^{76}$. 


\subsection{Material e Métodos}

\subsubsection{Exposição dos túbulos axial ou perpendicularmente ao corte.}

Doze amostras foram obtidas a partir de raiz unirradicular humana seccionada ao meio, sendo um lado usado como controle e outro irradiado, ambos da mesma raiz. De cada hemi-secção, obteve-se três amostras transversais (apical, médio e cervical), com os túbulos aparentes e outras três amostras longitudinais, com as paredes dos túbulos aparentes (Figura 7).

As amostras foram reduzidas a espessuras menores que $100 \mu \mathrm{m}$ para as medidas espectroscópicas.

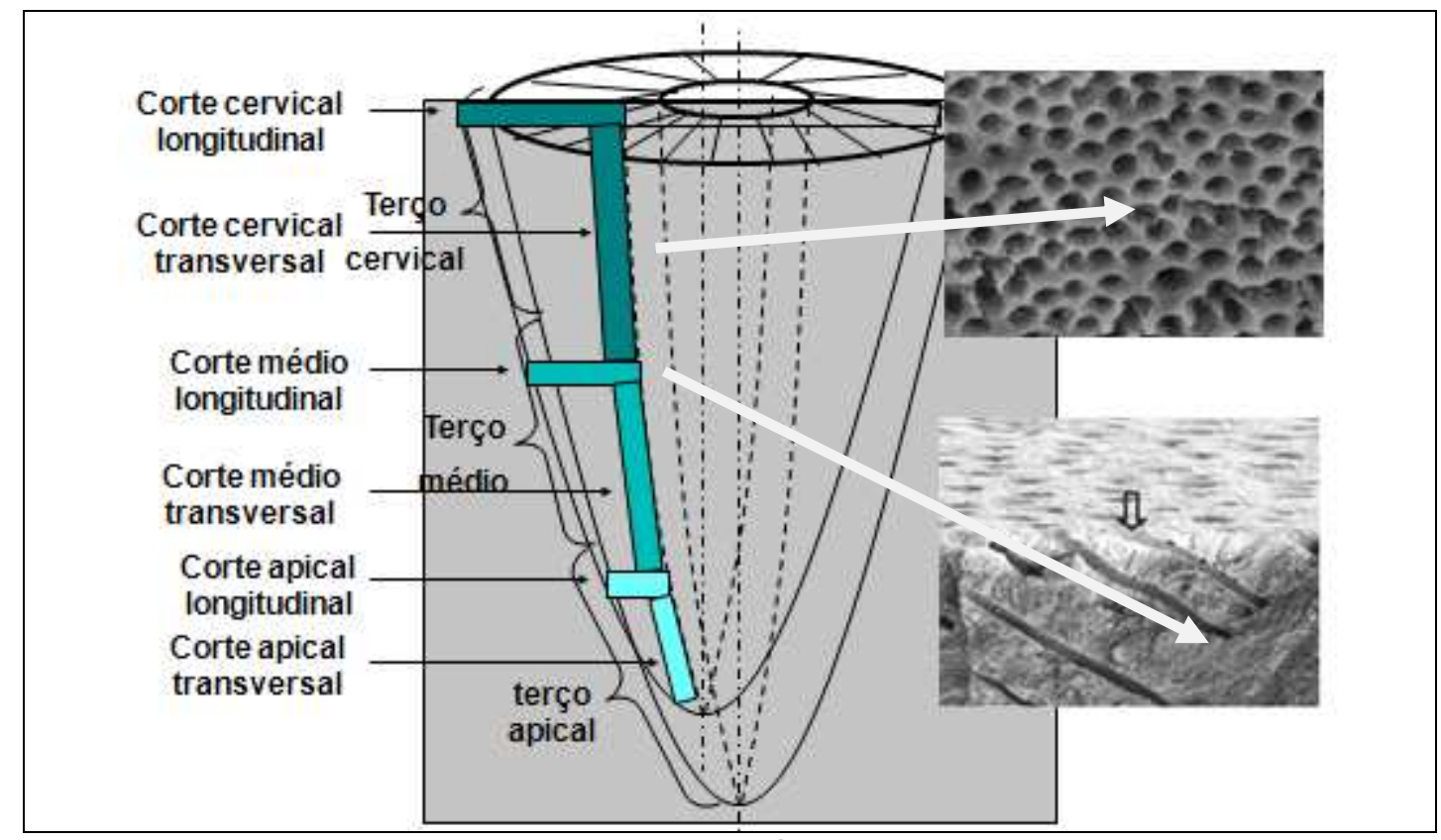

Figura 7: Esquema de corte em relação aos túbulos para obtenção de amostras. Observa-se diferença entre o aspecto das superfícies, considerando que as amostras empregadas nos grupos controle e irradiado são da mesma raiz.

\subsubsection{Irradiação laser.}

As amostras irradiadas foram fixadas em uma mesa com motor de controle de movimento automático contínuo nos eixos $\mathrm{X}$ e $\mathrm{Y}$. O feixe foi 
entregue por uma fibra de $600 \mu \mathrm{m}$ fixada perpendicularmente ao espécime, irradiando-se no mesmo eixo e perpendicular ao mesmo de acordo com o grupo avaliado (Figura 8). O deslocamento do feixe foi o equivalente ao diâmetro do feixe, calculado por: $D_{\text {eft }}=\left(1-1 / e^{2}\right) \times 600 \mu \mathrm{m}$ sendo, portanto, de $519 \mu \mathrm{m}$. Houve com este procedimento a irradiação de toda a superfície, sem a sobreposição de pulsos. Toda a superfície das amostras foram irradiadas cinco vezes, o que simula a técnica empregada em procedimentos clínicos de utilização do laser intracanal.

A potência média no display foi de $0,5 \mathrm{~W}$ em $20 \mathrm{~Hz}$ (25mJ/ pulso). Utilizando-se um power/energy meter, a energia aferida foi $20 \mathrm{~mJ}$, resultando na densidade de energia de $9,46 \mathrm{~J} / \mathrm{cm}^{2}$, com o diâmetro de feixe assumido no cálculo descrito anteriormente.

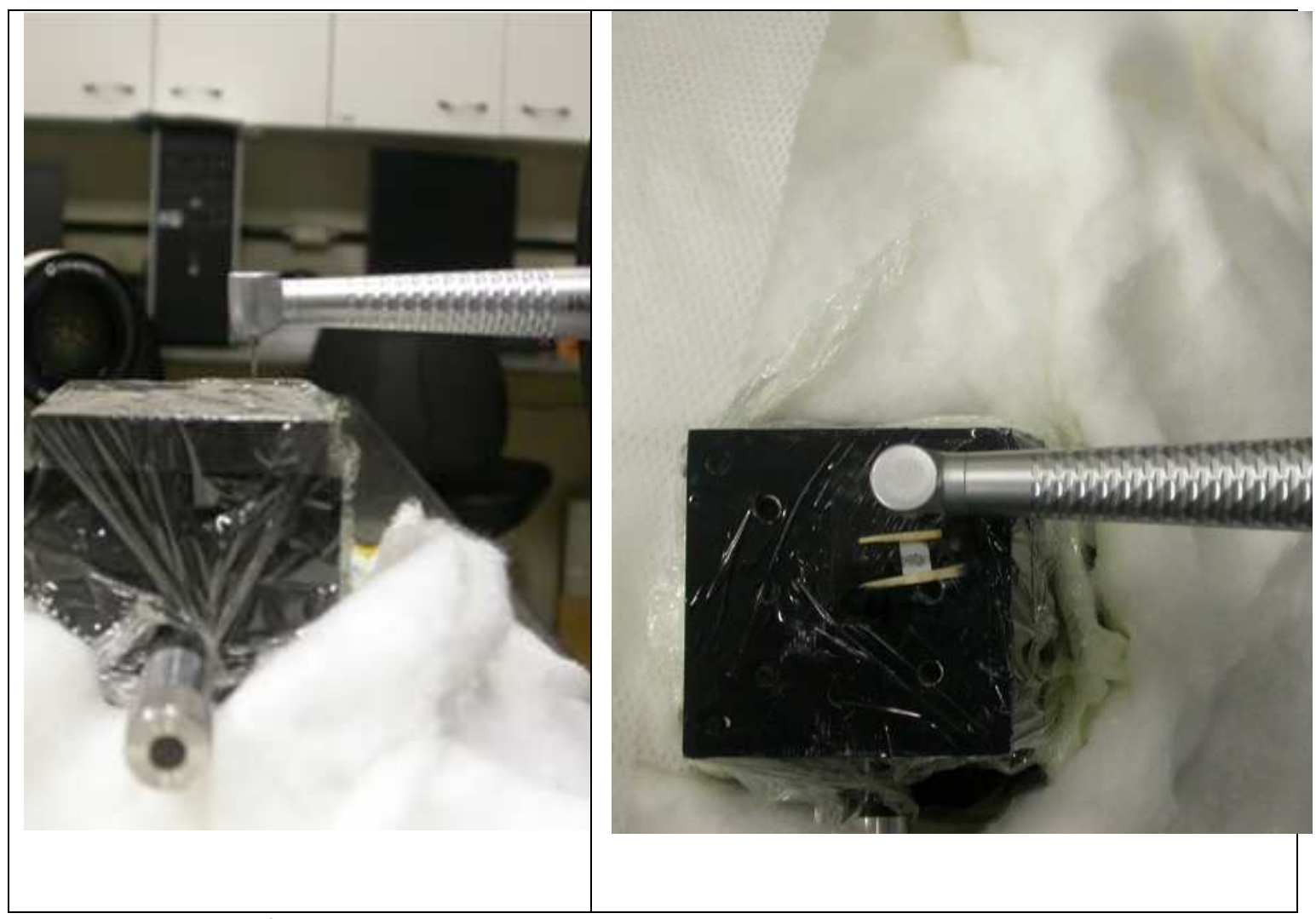

Figura 8: Controle de irradiação da amostra em relação ao feixe incidente. Deslocamentos iguais ao diâmetro do feixe para não causar sobreposição de pulso. 


\subsubsection{Espectroscopia por ATR-FTIR}

Para a obtenção dos espectros para análise, foi utilizado o espectrômetro FTIR ${ }^{* i i i}$ (6700, Thermo Nicolet Instruments, Waltham, MA, EUA) acoplado a um microscópio, com micro ATR (Atenuated Total Reflection) de objetiva montada com cristal de diamante (índice de refração 2,41 e ângulo de incidência de $45^{\circ}$ - Thermo Nicolet Instruments, Waltham, MA, EUA). A faixa de aquisição foi de 4000 a $800 \mathrm{~cm}^{-1}$, com passo de $6 \mathrm{~cm}^{-1}$ e 64 repetições. As bandas de interesse foram: Amida I (1815 a $1590 \mathrm{~cm}^{-1}$ ); amida II (1591 a 1490 $\mathrm{cm}^{-1}$ ); carbonato (1491 a $1350 \mathrm{~cm}^{-1}$ ); amida III (1351 a $1180 \mathrm{~cm}^{-1}$ ); fosfato (1181 a $886 \mathrm{~cm}^{-1}$ ) e carbonato (887 a $\left.800 \mathrm{~cm}^{-1}\right)$, que são constituintes orgânicos e inorgânicos da dentina humana (Figura 9). Nesta região espectral estão localizados os componentes orgânicos de interesse na adesão das resinas.

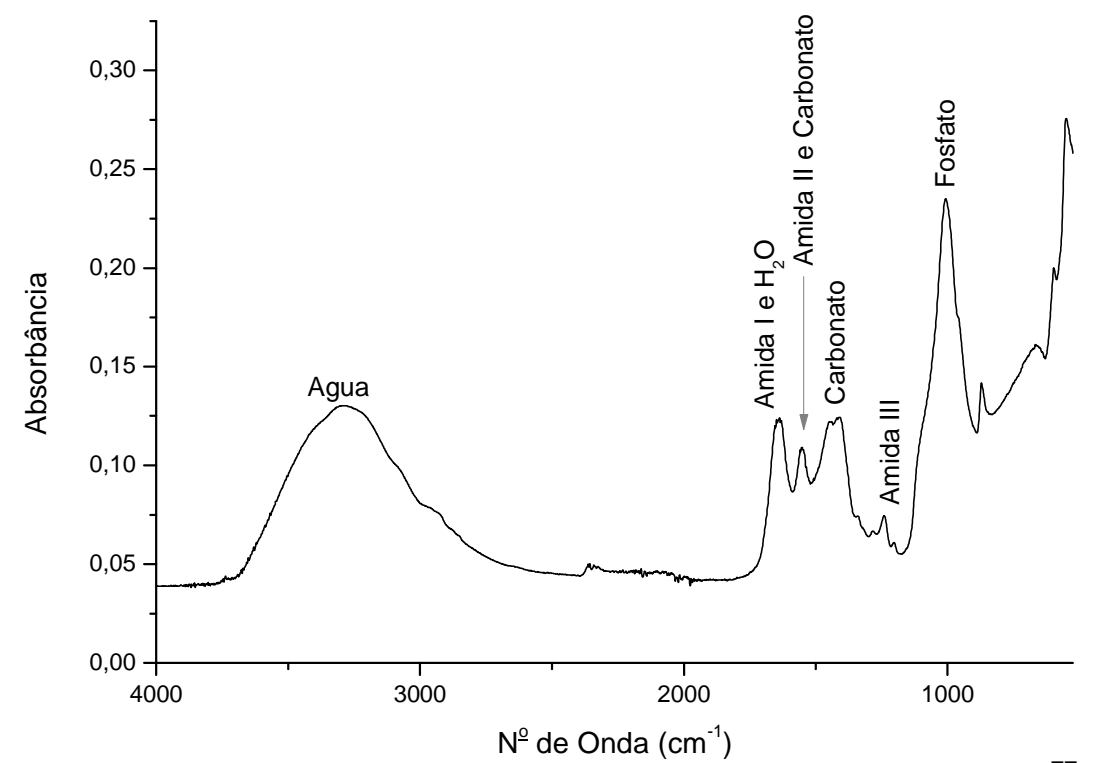

Figura 9: Espectro de absorção por FTIR típico para dentina ${ }^{77}$.

\footnotetext{
iii Projeto CEPOF-FAPESP , processo CEPID 05/51689-2
} 


\subsection{Resultados da espectroscopia ATR-FTIR}

A Figura 10 apresenta os espectros obtidos das diferentes regiões da dentina (apical, médio e cervical) para as amostras não irradiadas, tanto para as amostras em corte transversal quanto longitudinal.

A região apresentada é de 2000 a $700 \mathrm{~cm}^{-1}$, uma vez que nesta região se encontram as bandas correspondentes aos compostos orgânicos. Para que fosse possível a comparação dos espectros das diferentes regiões, os espectros foram normalizados pela intensidade da banda do fosfato (localizada em aproximadamente $970 \mathrm{~cm}^{-1}$ ).

A
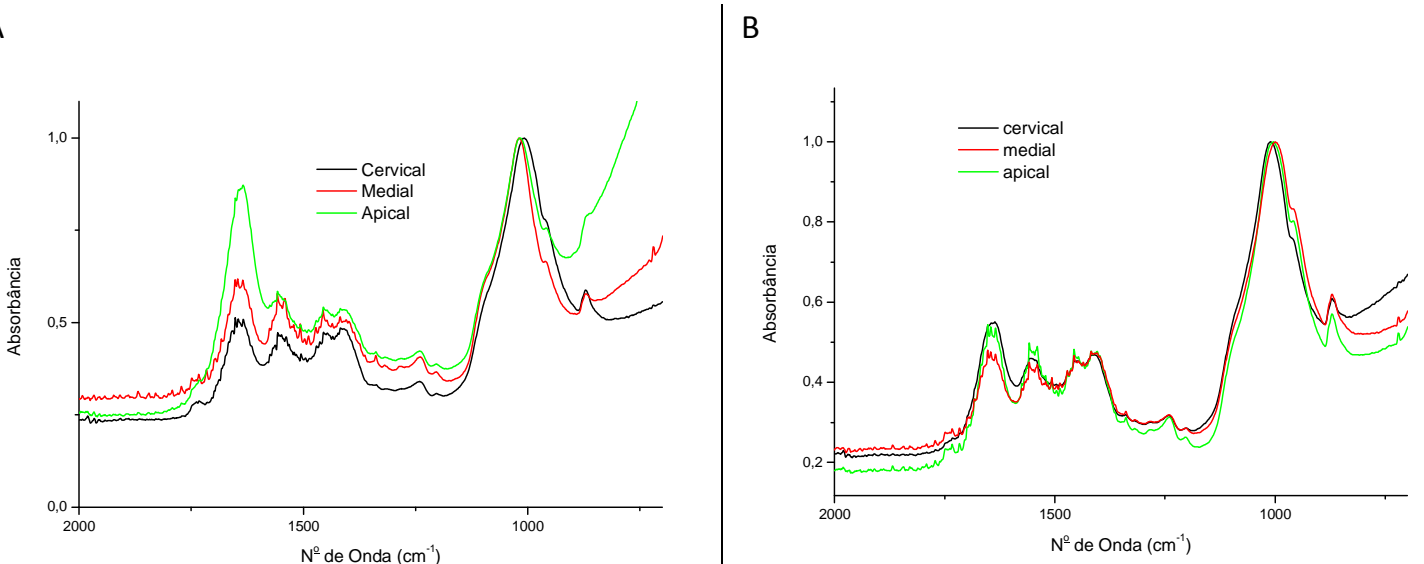

Figura 10: Comparação dos espectros obtidos das regiões cervical, medial e apical da dentina em corte $(A)$ transversal e (B) longitudinal.

A Figura 11 apresenta os espectros obtidos das amostras não irradiadas de uma mesma região da dentina em função da direção do corte. A região apresentada é de 2000 a $700 \mathrm{~cm}^{-1}$, por conter as bandas de interesse, uma vez 
que nesta região se encontram as bandas correspondentes aos compostos orgânicos. Para possibilitar a comparação dos espectros nas diferentes regiões eles foram normalizados pela intensidade da banda do fosfato (localizada em aproximadamente $970 \mathrm{~cm}^{-1}$ ).

A

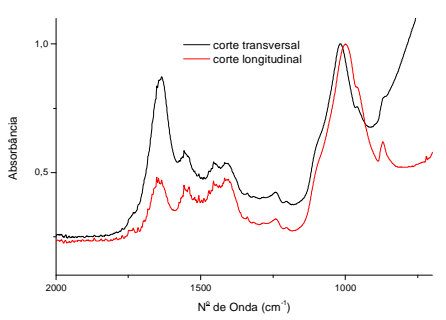

B

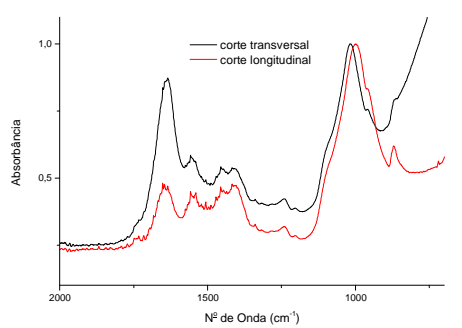

$\mathrm{C}$

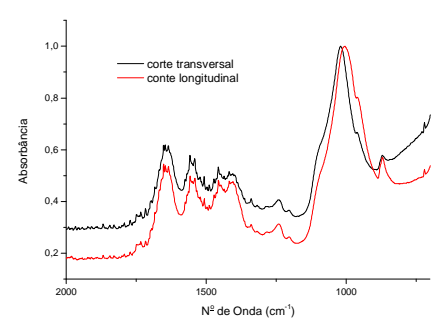

Figura 11: Comparação dos espectros obtidos das amostras cortadas no sentido transversal e longitudinal das regiões (A) Cervical, (B) Média e (C) Apical.

A Figura 12 apresenta os espectros das amostras não irradiadas e irradiadas das regiões apical, média e cervical nos cortes transversal e longitudinal. A região entre 2000 a $700 \mathrm{~cm}^{-1}$ contém as bandas de interesse, uma vez que nesta região se encontram as bandas correspondentes aos compostos orgânicos.

Os espectros foram normalizados pela intensidade da banda do fosfato (localizada em aproximadamente $970 \mathrm{~cm}^{-1}$ ) para ser possível a comparação dos espectros das diferentes regiões. 


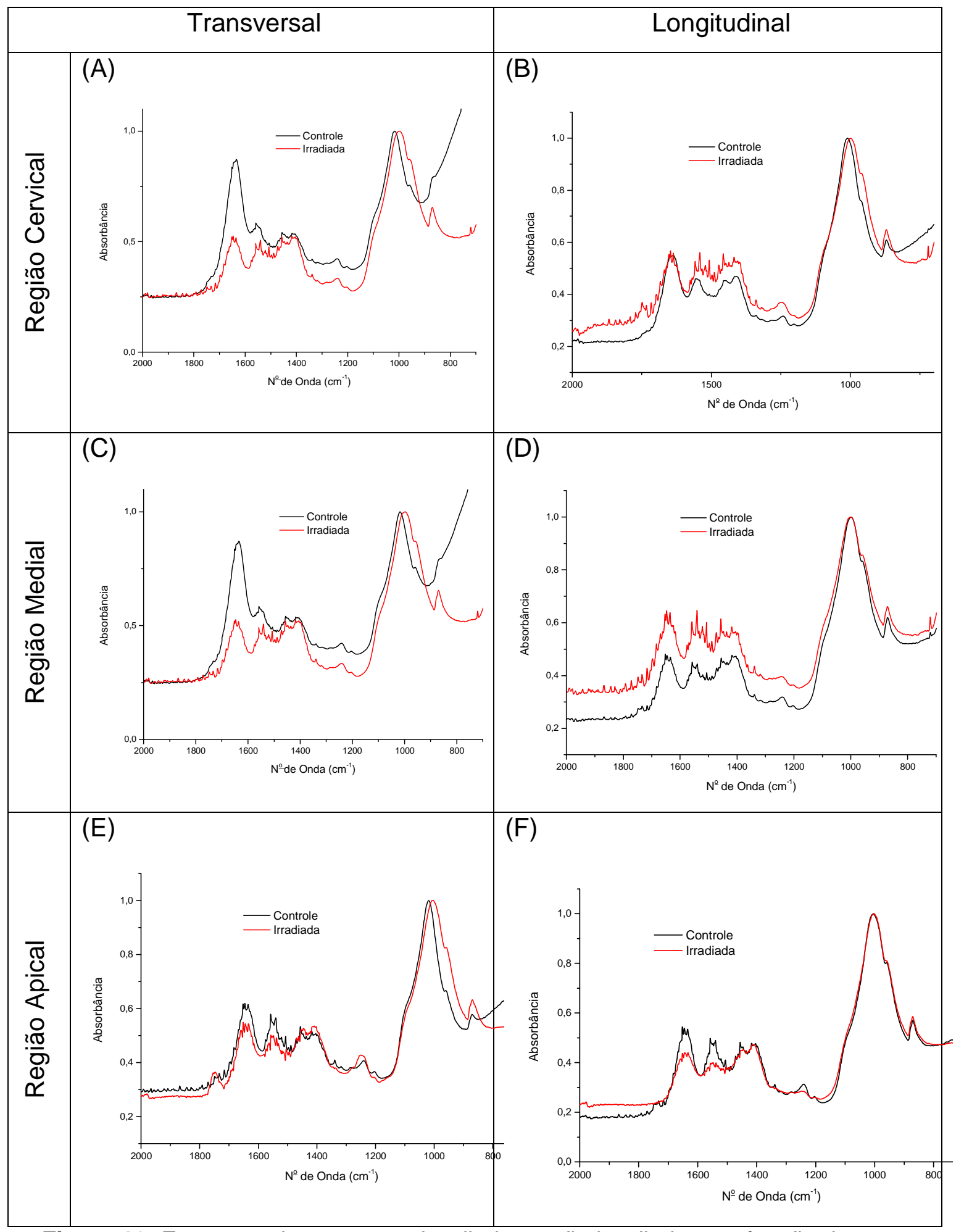

Figura 12: Espectros das amostras irradiadas e não irradiadas em função do corte transversal ou longitudinal, nas regiões cervical, média e apical. 


\section{ANÁLISE DE ENSAIOS MECÂNICOS DE PUSH-OUT}

As medidas de ensaios mecânicos são parâmetros utilizados em trabalhos científicos que avaliam a eficácia de procedimentos de adesão a dentina. O aumento da resistência a uma força de remoção aplicada, dividida pela área da região ensaiada, significa a melhor condição do ensaio. Neste estudo foi escolhido o método de compressão para o deslocamento de uma porção do núcleo (a raiz dividida em frações), conhecido como push-out.

\subsection{Material e Métodos}

\subsubsection{Preparo dos espécimes para tratamento endodôntico inicial.}

Noventa raízes dentais humanas unirradiculares foram separadas da coroa na junção amelo-cementaria radicular, na altura das faces proximais. 0 corte foi realizado em uma cortadeira de alta precisão (Accutom 5- Struers, Cleveland, $\mathrm{OH}, \mathrm{EUA})$ com disco diamantado de dupla face de corte nas dimensões de $76 \times 0,15 \mathrm{~mm}$ (HD - Struers, Cleveland, OH, EUA), com refrigeração abundante de água.

Para o tratamento endodôntico dos condutos radiculares foi usada instrumentação mecânica com sistema de instrumentos rotatórios de níqueltitânio (Protaper; Dentisply/Maillefer ,Ballalgues, Suíça) e técnica de preparo preconizada pelo fabricante, a $1 \mathrm{~mm}$ do forame apical com alargamento do conduto até o número $30^{73}$. O preparo apical final foi realizado com lima manual.

O preparo químico-mecânico foi irrigado com solução de hipoclorito de sódio a 2,5\% em cada troca de instrumento, com irrigação final com 
clorhexidina a $2 \%$.

Em seguida os condutos foram obturados conforme técnica endodôntica convencional de condensação lateral utilizando-se o cimento AH Plus (Dentisply/Detray, Konstans, Alemanha) e cones de guta-percha padronizados de número 35 (Denstisply, Petrópolis, Rio de Janeiro, Brasil).

Os noventa espécimes foram divididos randomicamente em nove grupos com dez repetições $(n=10)$ que receberam denominação de acordo com o tratamento aplicado (Tabela 2).

- Grupo I: Espécimes controle, sem irradiação e com núcleos cimentados com Variolink ${ }^{\circledR}$ II e Excite DSC ${ }^{\circledR}$;

- Grupo II: Espécimes controle, sem irradiação e com núcleos cimentados com Panávia ${ }^{\circledR} \mathrm{F}$;

- Grupo III: Espécimes controle, sem irradiação e com núcleos cimentados com Unicem ${ }^{\circledR}$;

- Grupo IV: Espécimes irradiados com feixe lateral e com núcleos cimentados com Variolink ${ }^{\circledR}$ II e Excite DSC ${ }^{\circledR}$;

- Grupo V: Espécimes irradiados com feixe lateral e com núcleos cimentados com Panávia ${ }^{\circledR} \mathrm{II}$;

- Grupo Vl: Espécimes irradiados com feixe lateral e com núcleos cimentados com Unicem ${ }^{\circledR}$;

- Grupo VII: Espécimes irradiados com feixe axial e com núcleos cimentados com Variolink ${ }^{\circledR}$ || e Excite DSC ${ }^{\circledR}$;

- Grupo VIII: Espécimes irradiados com feixe axial e com núcleos cimentados com Panávia ${ }^{\circledR} \|$;

- Grupo IX: Espécimes irradiados com feixe axial e com núcleos cimentados com Unicem ${ }^{\circledR}$; 
Tabela 2: Grupos para ensaio de push-out

\begin{tabular}{|c|c|c|c|c|c|}
\hline & $\begin{array}{l}\text { Laser } \\
\text { Axial }\end{array}$ & $\begin{array}{c}\text { Laser } \\
\text { Side firing }\end{array}$ & $\begin{array}{l}\text { Total-etching } \\
\text { (Variolink II) }\end{array}$ & $\begin{array}{c}\text { Self-etching } \\
\text { (Panavia) }\end{array}$ & $\begin{array}{c}\text { Self-adhesive } \\
\text { (Unicem) }\end{array}$ \\
\hline $\begin{array}{c}\text { Grupo I } \\
\text { (Controle) }\end{array}$ & & & Sim & & \\
\hline $\begin{array}{c}\text { Grupo II } \\
\text { (Controle) }\end{array}$ & & & & Sim & \\
\hline $\begin{array}{l}\text { Grupo III } \\
\text { (Controle) }\end{array}$ & & & & & Sim \\
\hline $\begin{array}{c}\text { Grupo IV } \\
\text { (Irradiado) }\end{array}$ & Sim & & Sim & & \\
\hline $\begin{array}{c}\text { Grupo V } \\
\text { (Irradiado) }\end{array}$ & Sim & & & Sim & \\
\hline $\begin{array}{c}\text { Grupo VI } \\
\text { (Irradiado) }\end{array}$ & Sim & & & & Sim \\
\hline $\begin{array}{l}\text { Grupo VII } \\
\text { (Irradiado) }\end{array}$ & & Sim & Sim & & \\
\hline $\begin{array}{l}\text { Grupo VIII } \\
\text { (Irradiado) }\end{array}$ & & Sim & & Sim & \\
\hline $\begin{array}{c}\text { Grupo IX } \\
\text { (Irradiado) }\end{array}$ & & Sim & & & Sim \\
\hline
\end{tabular}

\subsubsection{Preparo dos condutos radiculares para os núcleos em fibra.}

Para a remoção da guta percha intracanal e o alargamento dos condutos foi usada uma seqüência de instrumentos rotatórios tipo Gates Glidden, sendo a final de número três (diâmetro $0,9 \mathrm{~mm}$ ). O preparo final para o alojamento do retentor intracanal radicular foi realizado com um instrumento rotatório especial fornecido pelo fabricante do sistema. Este instrumento rotatório propicia a conformação final no conduto para receber o pino de resina. O sistema escolhido foi o de pino de fibra de vidro reforçado, cônico de superfície lisa, FRC Postec Plus ${ }^{\circledR}$ de número três (Ivoclar/Vivident, Schaan, Liechtenstein).

O seqüenciamento crescente de instrumentos rotatórios é necessário para evitar-se o aquecimento excessivo do conduto radicular, propiciando a redução da tensão produzida pelo atrito do instrumento rotatório com as paredes do conduto e assim minimizando assim a deposição de smear layer. 
Esta técnica é a mesma utilizada em rotina clínica. O comprimento total do preparo radicular para receber o pino foi de $10 \mathrm{~mm}$ tendo-se como referência a porção cervical da raiz.

A cavidade preparada foi irrigada com $2 \mathrm{ml}$ de $\mathrm{NaOCl}$ a 2,5\% e neutralizada com $5 \mathrm{ml}$ de água destilada. Todo o processo de irrigação foi feito com o auxilio de seringa cuja agulha foi posicionada no fundo da cavidade e a irrigação realizada em movimentos helicoidais de apical para cervical.

\subsubsection{Irradiação laser:}

As amostras do grupo laser foram irradiadas com laser Er,Cr:YSGG, comprimento de onda: 2,79 $\mu \mathrm{m}$, modelo Waterlase (Biolase, San Clemente,CA, EUA). como descrito no item Erro! Fonte de referência não encontrada. e utilizado um power/energy meter modelo FieldMaster GS (Coherent, Auburn, CA, EUA) com sensor LM 10P, do mesmo fabricante, para aferição das energia por pulso. Para facilitar a medição da energia foi colocado um espaçador entre a peça de mão do laser e o sensor (Figura 2). Com este recurso, facilitou-se a aferição de cada irradiação além uniformizar-se o procedimento. A aferição foi executada antes da irradiação de cada raiz.

Todos os condutos foram umedecidos antes da irradiação para melhoria das condições de ablação e minimizar as possibilidades de danos térmicos. As raízes foram mantidas em temperatura controlada de $22,9^{\circ} \mathrm{C}$ e umidade ambiente controlada de $34 \%$ por até 30 minutos antes dos procedimentos ${ }^{48}$.

Para este experimento, as duas condições de emissão da irradiação do feixe laser avaliadas foram: 


\subsubsection{Feixe Axial}

A ponta Z4 (Biolase, San Clemente, CA, EUA) de safira para irradiação endodôntica com $400 \mu \mathrm{m}$ de diâmetro e $20 \mathrm{~mm}$ de comprimento, com fator de transmissão de 0,75 , foi usada em contato com a parede interna do canal radicular (Figura 13) previamente tratado endodonticamente.

A energia de trabalho foi de $40 \pm 4 \mathrm{~mJ}$ e taxa de repetição em $20 \mathrm{~Hz}$ $\left(42,57 \mathrm{~J} / \mathrm{cm}^{2}\right)$ com $37 \%$ de água e $34 \%$ de ar. Foram executadas cinco irradiações de 10s de duração, em movimentos helicoidais da região apical para cervical e intervalo de tempo de 20 s para permitir a relaxação térmica. É de extrema importância a aferição da energia entregue pelo feixe, pois a potência média indicada no display do equipamento laser variou de 1,5 a $3 \mathrm{~W}$.

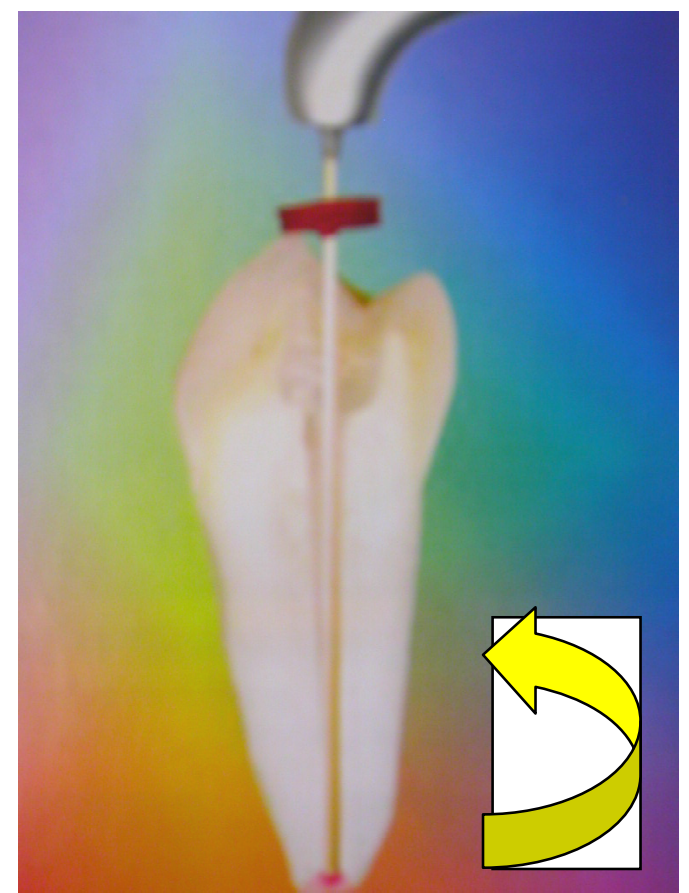

Figura 13: llustração da ponta Z4 posicionada durante a irradiação $0^{78}$ 


\subsubsection{Feixe lateral (side firing)}

A ponta endolase RTF3 (Biolase, San Clemente, CA, EUA) de safira para irradiação endodôntica com diâmetro de $415 \mu \mathrm{m}$ e $21 \mathrm{~mm}$ de comprimento, foi usada em contato com a parede interna do canal (Figura 14).

Foram executadas cinco irradiações de 10s, em movimentos helicoidais da região apical para cervical, com intervalo de 20s para permitir relaxação térmica. A potência média de 1,2W em $15 \mathrm{~Hz}\left(59,14 \mathrm{~J} / \mathrm{cm}^{2}\right)$ com $37 \%$ de água e $34 \%$ de ar.

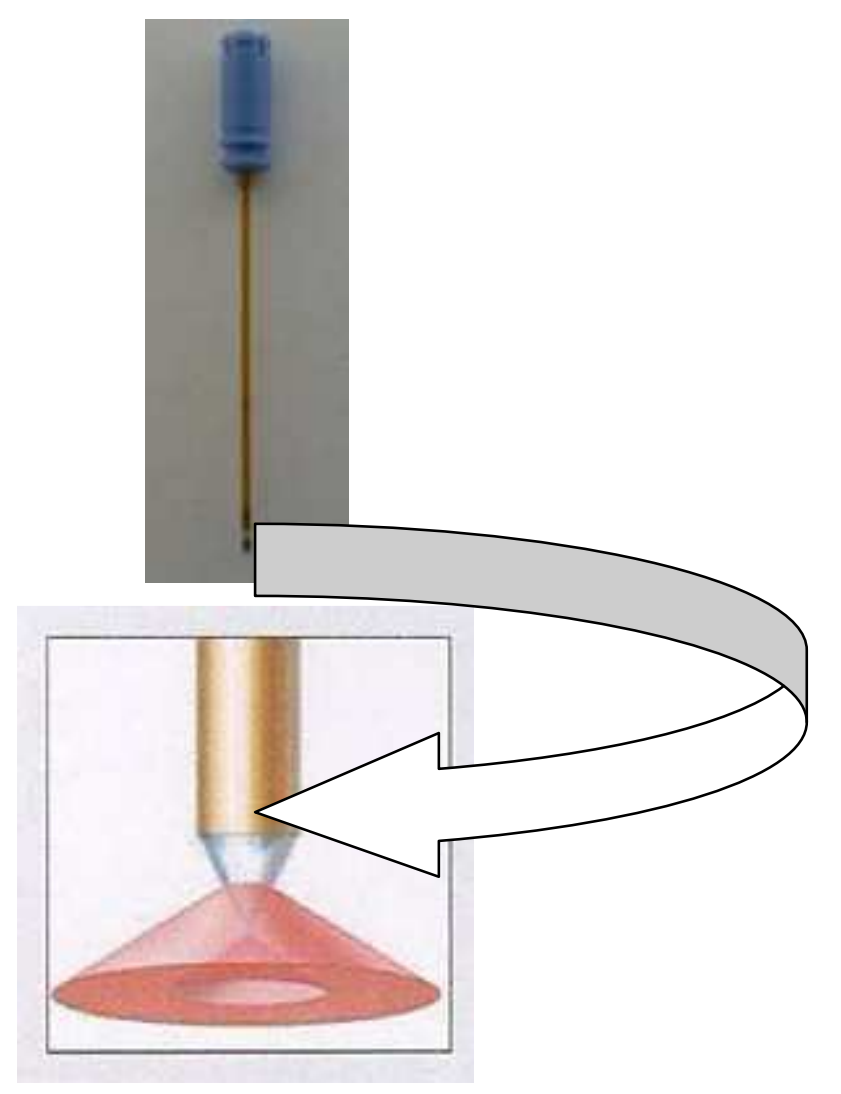

Figura 14: Foto da fibra RFT3. Ilustração em detalhe da grande abertura numérica apresentada pela fibra $\mathrm{RFT}^{78}$ 


\subsubsection{Preparo das superfícies dos pinos de fibra.}

Foram utilizados pinos de fibra de vidro FRC Postec Plus (Ivoclar/Vivadent, Schaan, Liechtenstein) número três, que são cônicos e têm superfície lisa. A superfície foi tratada com ácido fosfórico por um minuto, enxaguada com água abundante e seca com jato de ar, segundo recomendação do fabricante. Imediatamente após, foi aplicada uma camada uniforme de primer (Monobond, Ivoclar/Vivadent, Schaan, Liechtenstein), após a reação por um minuto, o excesso foi removido com jato de ar, aplicado por toda a superfície, durante 15 segundos. Este procedimento ocorreu em ato contínuo à cimentação do núcleo, sendo que sua superfície não foi manuseada até sua colocação no conduto radicular.

\subsubsection{Cimentação de núcleos e formação dos grupos:}

Foram empregados três diferentes tipos de cimentos resinosos do tipo dual, cada um representando um sistema diferente de adesão: 1) Total-etching: Variolink II + excite DSC (Ivoclar/Vivadent, Schaan, Liechtenstein), 2) selfetching: Panavia F (Kuraray Medical inc., Okayama, Japão) e 3) self-adhesive: RelyX Unicem Aplicap (3M ESPE AG, Seefeld, Alemanha).

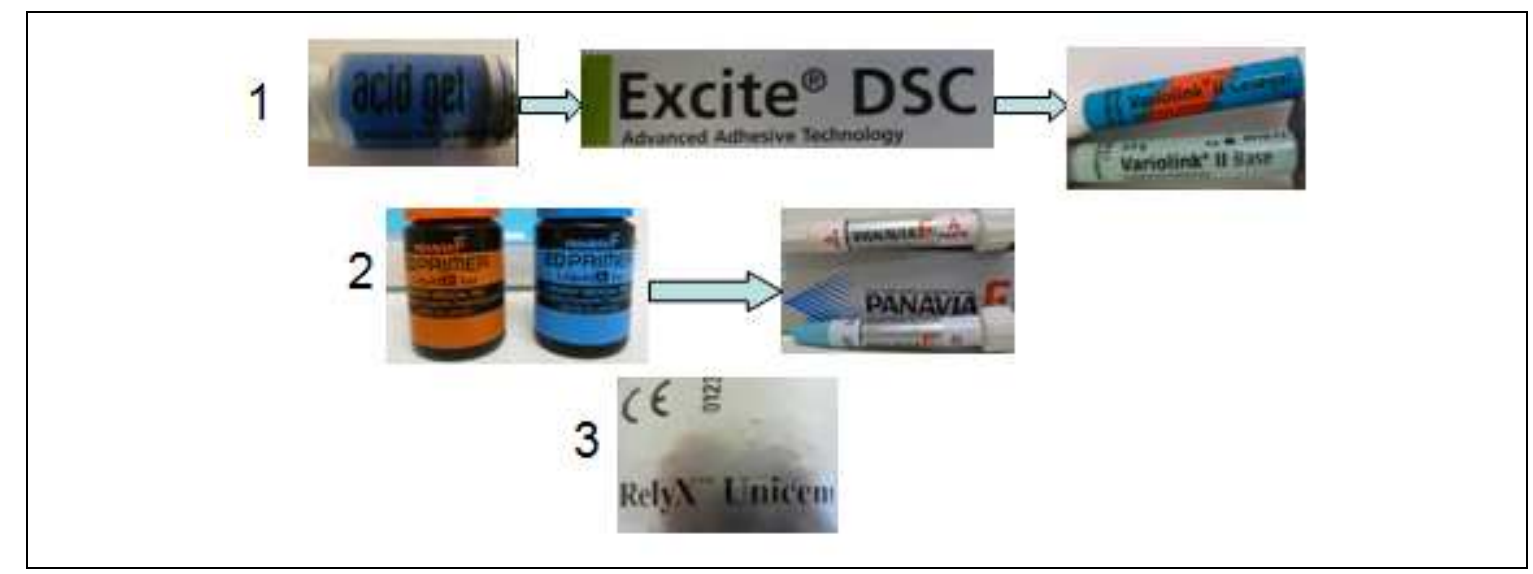

Figura 15: Esquema dos sistemas adesivos. 1- Total-etching (Variolink II + excite DSC); 2- self-etching (Panavia F); 3- self-adhesive (Rely X RelyX Unicem Aplicap). 
Para padronização e semelhança com a situação clínica, de maneira mais fiel possível, os pinos foram fixados imediatamente após o preparo dos condutos nos grupos controle ou imediatamente após a irradiação dos condutos, nos grupos irradiados.

O cimento foi aplicado diretamente sobre a superfície dos pinos e estes colocados nos condutos. Os fabricantes dos três sistemas contra indicaram o uso de instrumentos rotatórios tipo lentulo para aplicação do cimento no interior do conduto.

O excesso do cimento foi removido com o auxilio de um explorador clínico odontológico.

Após essa etapa, os pinos foram mantidos sob pressão no sentido ocluso-apical durante dois minutos, tempo necessário para a polimerização do cimento.

Apesar dos cimentos serem do tipo dual, houve a fotopolimerização por 60 segundos para assegurar melhor polimerização das resinas utilizadas. Foi utilizado um fotopolimerizador com densidade de potência de $500 \mathrm{~mW} / \mathrm{cm}^{2}$ (Optilight plus, Gnatus, Ribeirão Preto, SP, Brasil)

Imediatamente após a cimentação, todos os espécimes foram identificados, acondicionados em câmara incubadora (Marconi, Piracicaba, SP, Brasil) e mantidos por 48 horas em temperatura constante de $37^{\circ} \mathrm{C}$ em umidade de $100 \%{ }^{79}$. 


\subsubsection{Cimentação com técnica de total-etching:}

\subsection{Grupo I (controle - total-etching);}

\subsection{Grupo IV (irradiado axial - total-etching);}

7.1.5.1.3 Grupo VII (irradiado radial ou side firing - total-etching).

Os condutos radiculares preparados para receberem os pinos de fibra foram condicionados com ácido fosfórico a $35 \%$ por 15 segundos. Em seguida o conduto foi irrigado com água, até a remoção total do ácido, e seco com cones de papel absorventes (Roeko, Coltène/Whaledent, Langenau, Alemanha). Teve-se o cuidado de não desidratar a dentina, pois esta técnica exige ligeira umidade do conduto (wet bonding)

Foi utilizado um adesivo dual (Excite DSC, Ivoclar/Vivadent, Schaan, Liechtenstein) que acompanha um frasco dosador e aplicador apropriado para conduto radicular, o conjunto necessita ser ativado antes da utilização. $O$ adesivo foi aplicado em toda a superfície do preparo para o pino, permanecendo em contato por 30 segundos, e a seguir, uma segunda demão foi aplicada, para assegurar a penetração adequada do adesivo no interior dos túbulos dentinários. O excesso de adesivo foi removido com o auxilio de cones de papel absorventes endodônticos (Roeko, Coltène/Whaledent, Langenau, Alemanha) e segundo orientação do fabricante não foi fotopolimerizado 0 adesivo, uma vez que o cimento utilizado foi do tipo dual.

O cimento de cura dual (Variolink II, Ivoclar/Vivadent, Schaan, Liechtenstein) foi manipulado na proporção 1:1 de pasta base e pasta catalisadora de baixa viscosidade, com espátula plástica sobre bloco de papel apropriado. 


\subsubsection{Cimentação com técnica de self-etching:}

7.1.5.2.1 Grupo II (controle - self-etching);

7.1.5.2.2 Grupo V (irradiado axial - self-etching);

7.1.5.2.3 Grupo VIII (irradiado radial ou side firing - self-etching)

Nesta técnica não é realizado o condicionamento ácido total da dentina, pois o primer é do tipo auto-condicionante, isto é, faz o condicionamento da dentina. O primer que acompanha o kit do cimento Panavia F (Kuraray Medical inc., Okayama, Japão), denominado ED primer, é encontrado em dois frascos (primer A e primer B). Duas gotas foram misturadas para ativação e aplicadas sobre as paredes dos condutos radiculares com o auxilio de um pincel tipo micro-brush. Decorridos 30 segundos, tempo de atuação sobre as paredes da dentina intracanal radicular, o excesso foi removido com cones de papel absorventes (Roeko, Coltène/Whaledent, Langenau, Alemanha).

O cimento tipo dual Panavia F (Kuraray Medical inc., Okayama, Japão) apresenta-se na forma de duas pastas (pasta A e pasta B) dosadas na mesma proporção, e manipuladas sobre bloco de papel com espátula plástica.

Após a remoção do excesso do cimento foi aplicada uma camada de Oxyguard II (Kuraray Medical inc., Okayama, Japão) sobre a interface pino e cimento para impedir o contato com o ar, uma vez que esta resina na polimeriza na presença de oxigênio. 


\subsubsection{Cimentação com técnica de self-adhesive:}

7.1.5.3.1 Grupo III (controle - self-adhesive);

7.1.5.3.2 Grupo VI (irradiado axial - self-adhesive);

7.1.5.3.3 Grupo IX (irradiado radial ou side firing - self-adhesive).

Nesta técnica não é usado qualquer condicionante, primer ou adesivo prévio, apenas o preparo inicial comum a todos os grupos. Foi utilizado o RelyX Unicem Aplicap (3M ESPE AG, Seefeld, Alemanha) em forma de aplicap que são capsulas em doses individualizadas, preparadas no instante da utilização, por agitação mecânica.

Para a ativação inicial do conteúdo da cápsula e iniciar sua mistura interna, utiliza-se um aparato denominado Aplicap activador que acompanha o kit. Nele há um nicho para a colocação da cápsula e uma alavanca que pressiona a cápsula, a qual deve ser pressionada por um período de 2 a 4 segundos.

Em seguida, a cápsula ativada foi para a fase de mistura, sendo mantida em um agitador de alta freqüência (4000/min.- Gnatus softly-Ribeirão Preto, SP, Brasil) por 20 segundos e colocada em um aplicador apropriado (Aplicac applier) que acompanha o kit.

A cápsula possui uma cânula para aplicação do cimento e para emprego intracanal, é utilizado um prolongamento apropriado, RelyX Unicem Aplicap Elongation Tips (3M ESPE, S.Paul, MN, EUA). 


\subsubsection{Corte do espécime em discos para ensaio (corpos de prova).}

Após a cimentação dos núcleos nos condutos, estes foram seccionados em cortes de $1 \mathrm{~mm}$. A partir da porção coronária, foram obtidos seis discos para ensaio mecânico de cada raiz, sendo dois discos para cada terço do núcleo.

Foram obtidos 540 discos (corpos de prova). Esse número propicia maior acuidade das medidas e na comparação do comportamento mecânico inter e intra-grupos.

Os cortes foram executados perpendiculares ao longo eixo dos pinos com uma cortadeira de precisão (Accutom 5- Struers, Cleveland, OH, EUA) com disco diamantado de dupla face de corte nas dimensões de $76 \times 0,15 \mathrm{~mm}$ (Struers, Cleveland, OH, EUA), em 600 RPM e velocidade de avanço de 0,2 $\mathrm{mm} /$ minuto com refrigeração abundante de água (Figura 16 A).

Os discos cortados foram acomodados em recipiente tipo placa de cultura esterilizada com 96 poços (TPP, Basel, Suíça)(Figura 16 B), umedecidos e refrigerados. O intervalo de tempo entre o corte dos corpos de prova e o ensaio de compressão foi menor que 24 horas.

Para facilitar o ensaio de compressão e por se tratar de um pino cônico foi realizada a identificação da porção apical com caneta de tinta indelével. 


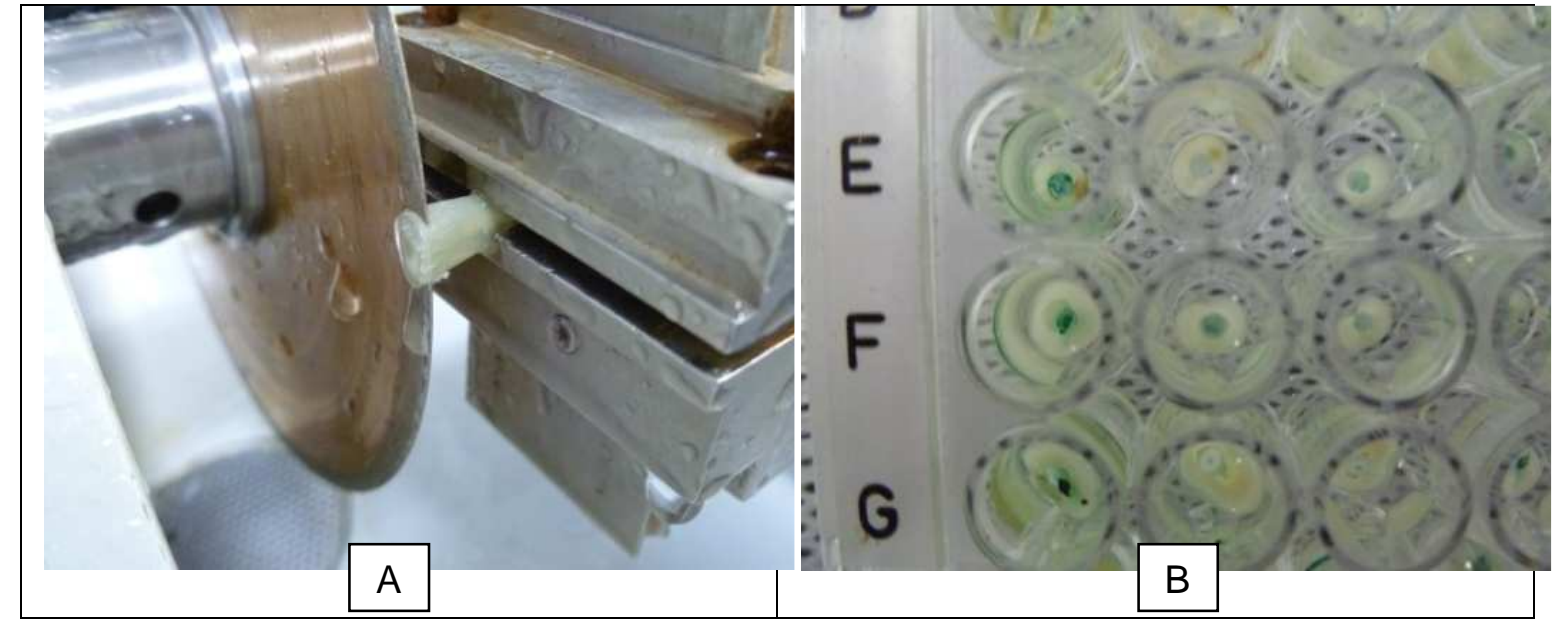

Figura 16: A- Corte das amostras para obtenção de discos (corpos de prova);

B- Corpos de prova posicionados nos casulos da placa

\subsubsection{Teste de compressão (push-out).}

Foi utilizada uma máquina de teste universal Instron 5567 (Norwood, MA, EUA), para a avaliação da força de resistência à compressão do núcleo cimentado no conduto radicular, com força aplicada ao longo eixo do núcleo e velocidade de $0,5 \mathrm{~mm} / \mathrm{min}$. A força máxima medida até o desalojamento do núcleo foi registrada.

Os valores obtidos em Newton foram convertidos em MPascal pela divisão pela área de contato (atrito) do núcleo com a parede intracanal radicular, $(\partial=F / A)$. Como o núcleo tem a forma cônica, a área da superfície de sua secção tronco-cônica foi calculada por meio da fórmula: 


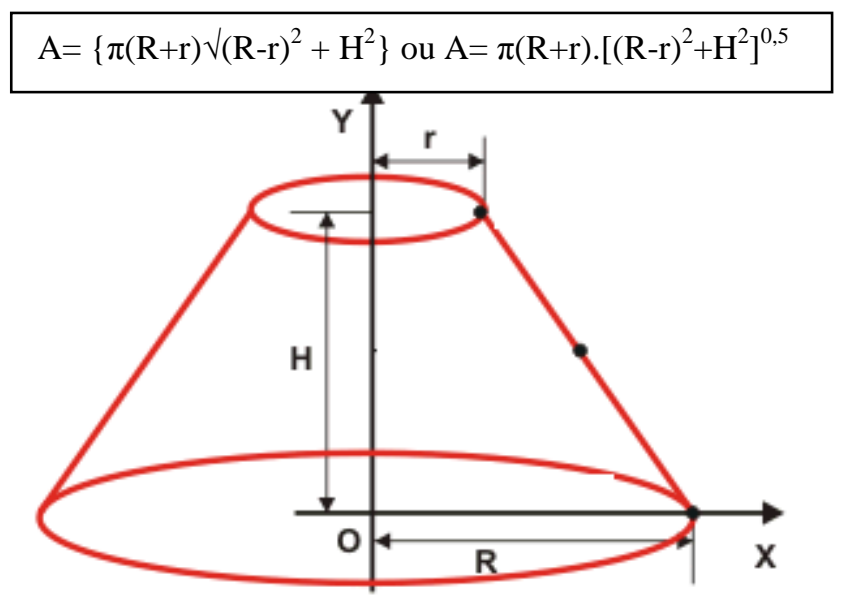

Figura 17: Fórmula e esquema para o calculo da área das amostras para a determinação da resistência de união adesiva

Para aferir as dimensões do núcleo em cada um dos corpo de prova foi utilizado um paquímetro digital (Mitutoyo- Japão).

A porção apical ficou voltada para a ponta de ensaio, pois o deslocamento se deu de apical para cervical, por se tratar de pino cônico.

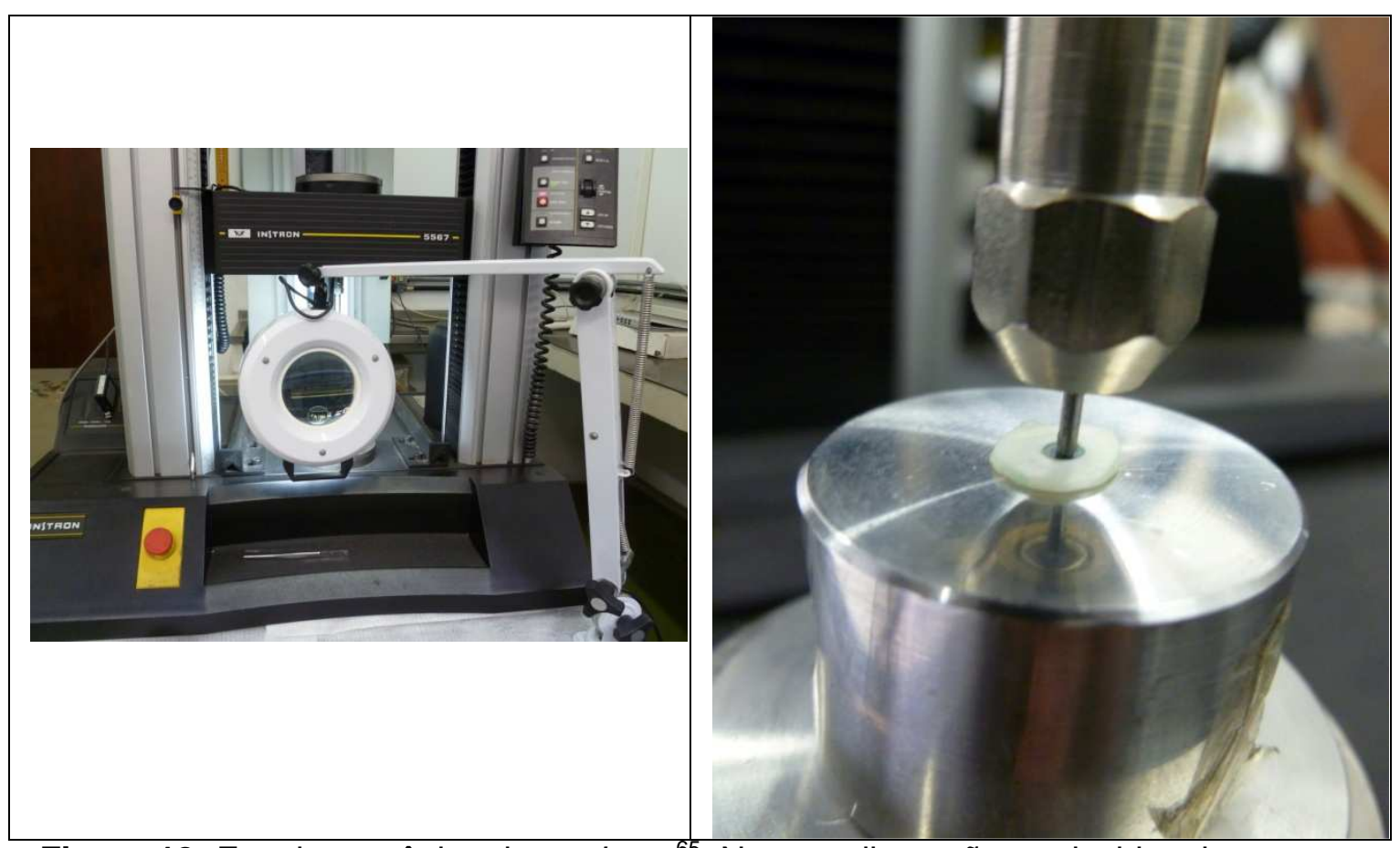

Figura 18: Ensaio mecânico de push-out $t^{65}$. Note as dimensões reduzidas dos corpos de prova. Para auxiliar na centralização foi usada uma lupa. 


\subsubsection{Avaliação estatística.}

Para a determinação da normalidade dos dados foi executado o teste de Shapiro-Wilk em conjunto com 0 teste de Levene para 0 teste da homogeneidade das variâncias. Como todos os dados apresentaram distribuição normal pelo teste de Shapiro-Wilk $(p>0,05)$ para a resistência de união adesiva $(\mathrm{MPa})$ nos dados de máxima pressão no ponto de fratura, foram empregados testes paramétricos.

Os dados de pressão foram agrupados em tabela para avaliação inter ou intra-grupos. Dentro do mesmo grupo foi avaliada a diferença entre os terços cervical, médio e apical. Entre grupos foi observado o comportamento do tratamento aplicado à raiz e o material empregado e o seu cruzamento entre os terços dos diversos grupos. O programa Statisctica 7.0 (StaSoft-inc, Tulsa, OK, EUA) foi utilizado para a avaliação dos dados coletados.

O teste de Levene foi usado nos dados obtidos para verificar a homogeneidade das variâncias. Nos casos em que as variâncias eram homogêneas foi aplicado o teste de análise de variância (Anova).

Quando o teste Anova demonstrou diferenças estatisticamente significantes entre mais de dois grupos estudados, foi utilizado o teste complementar de Tukey para determinar onde está a diferença. A análise de variância one-way (ANOVA) associada ao teste de Tukey post-hoc foi aplicado para múltiplas comparações dos grupos com homogeneidade de variâncias $(p>0.05)$

O teste t foi aplicado para variâncias diferentes, dois a dois, onde no teste de Levene o valor de $p<0,05$, foi corrigido pelo método de Ryan-Holn step down Bonferroni. 


\subsection{Resultados dos ensaios de push-out}

\subsubsection{Resultados da irradiação axial.}

Para analisar a influência da irradiação nos grupos laser para os diferentes cimentos utilizados e a relação em cada terço, foi comparado com seu equivalente nos grupos controle. O nível de significância p para a hipótese testada foi obtida pelo teste t juntamente com o nível de homogeneidade da variância obtida pelo teste de Levene é apresentada na Tabela 3.

A análise estatística demonstrou que a irradiação com laser de Er,Cr:YSGG dentro dos canais radiculares antes da cimentação de um núcleo protético em fibra de vidro reforçada com Panavia F e Relyx Unicem Aplicap afeta significativamente a resistência de união adesiva ( $p=0.05$, Tabela 3).

Tabela 3: Níveis (p) corrigidos pelo teste de Ryan-Holm step-down Bonferroni, para comparações intra-grupos fibra axial

\begin{tabular}{|l|c|c|}
\hline & t-teste (p) & Levene (p) \\
\hline $\begin{array}{l}\text { Variolink Cerv. (control) vs. } \\
\text { Irradiado Variolink Cerv. }\end{array}$ & 0,589040 & 0,537171 \\
\hline $\begin{array}{l}\text { Variolink Médio (controle) vs. } \\
\text { Irradiado Variolink Médio }\end{array}$ & 0,896640 & 0,935241 \\
\hline $\begin{array}{l}\text { Variolink Apical (controle) vs. } \\
\text { Irradiado Variolink Apical }\end{array}$ & 0,677657 & 0,487417 \\
\hline $\begin{array}{l}\text { Panavia Cerv. (controle) vs. } \\
\text { Irradiado Panavia Cervical }\end{array}$ & 0,832055 & 0,264249 \\
\hline $\begin{array}{l}\text { Panavi Médio (controle) vs. } \\
\text { Irradiado Panavia Médio }\end{array}$ & $\underline{{ }^{0}, 034176}$ & $\underline{\text { 0,000793 }}$ \\
\hline $\begin{array}{l}\text { Panavia Apical (controle) vs. } \\
\text { Irradiado Panavia Apical }\end{array}$ & 0,233234 & 0,163818 \\
\hline $\begin{array}{l}\text { Unicem Cer.(Contrl) vs. } \\
\text { Irradiado Unicem Cerv. }\end{array}$ & $\underline{* 0,006783}$ & 0,562708 \\
\hline $\begin{array}{l}\text { Unicem Médio (Contrl) vs. } \\
\text { Irradiado Unicem Médio }\end{array}$ & $\underline{\text { 0,006645 }}$ & 0,540767 \\
\hline $\begin{array}{l}\text { Unicem Apical (contrl) vs. } \\
\text { Irradiado Unicem Apical }\end{array}$ & $\mathbf{0 , 0 8 2 0 8 6}$ & 0,260813 \\
\hline
\end{tabular}

[ ${ }^{\star}$ Para $(p<0,05)$ foi utilizado o teste para variâncias diferentes]

No grupo irradiado e cimentado com Panavia $F$ (grupo V), no terço médio, houve aumento na resistência de união adesiva estatisticamente 
significativa $(p=0,034)$ em relação ao grupo controle (grupo II)(Tabela 3, Figura 19).

O uso do RelyX Unicem Aplicap com núcleos FRC postec plus nas amostras irradiadas (grupo VI) estatisticamente aumenta a resistência de união adesiva em todos os terços (cervical, médio e apical) entre todos os outros grupos $(p<0,02)($ Tabela 4, Tabela 5 e Figura 19).

Aplicando-se o teste de Anova nos grupos controle (não irradiados), obteve-se o nível de $p=0,95$ para o terço cervical e $p=0,18$ para o terço apical, demonstrando não haver diferença estatística significante entre essas regiões nos grupos não irradiados. No terço médio dos grupos controle, o teste de Levene apresentou $p=0,0037$, portanto ANOVA não é uma hipótese válida. $A$ Tabela 4 mostra o nível p obtido pela comparação múltipla de dados pareados, assumindo-se diferentes variâncias. Os valores de p estão corrigidos pela múltiplas correlações.

Para os casos de Levene com $p<0,05$ foi utilizado o teste $t$ para variâncias diferentes.

Tabela 4: Níveis ( $p$ ) corrigidos pelo teste de Ryan-Holm step-down Bonferroni para comparações entre - grupos controle.

\begin{tabular}{|c|c|c|}
\hline & Anova & Levene \\
\hline Controle cervical & 0,953000 & 0,441000 \\
\hline Controle médio & Nao é possivel & $\underline{{ }^{*} 0,003472}$ \\
\hline Controle apical & 0,18 & 0,45 \\
\hline *Terço médio & Variolink & Panavia \\
\hline Panavia & 0,168 & \\
\hline Unicem & 0,164 & ${ }^{*} 0,0012$ \\
\hline
\end{tabular}

[ ${ }^{\star}$ Para $(p<0,05)$ foi utilizado o teste para variâncias diferentes]. 
Tabela 5: Níveis (p) corrigidos pelo teste de Ryan-Holm step-down Bonferroni para comparações entre-grupos controle.

\begin{tabular}{|c|c|c|}
\hline & Anova & Levene \\
\hline Irradiado axial cervical & $\underline{0,0049 *}$ & 0,6 \\
\hline Irradiado axial médio & não é possivel & $\underline{0,048273^{\star \star}}$ \\
\hline Irradiado axial apical & $\underline{0,0000^{* * *}}$ & 0,678 \\
\hline *Terço cervical & Variolink & Panavia \\
\hline Panavia & 0,943599 & \\
\hline Unicem & $\underline{0,019933^{*}}$ & $\underline{0,008315^{\star}}$ \\
\hline **Terço médio & Variolink & Panavia \\
\hline Panavia & 0,660179 & \\
\hline Unicem & $\underline{0,000068^{*}}$ & $\underline{0,000294^{*}}$ \\
\hline ***Terço apical & Variolink & Panavia \\
\hline Panavia & $\underline{0,035088^{*}}$ & \\
\hline Unicem & $\underline{0,000027^{*}}$ & $\underline{0,000000^{* *}}$ \\
\hline
\end{tabular}

[ ${ }^{\star}$ Para $(p<0,05)$ foi utilizado o teste para variâncias diferentes]

No grupo irradiado e cimentado com Variolink II houve aumento estatisticamente significante da resistência de união adesiva no terço apical em comparação aos resultados do Panavia $F(p<0,05)$ (Tabela 5 e Figura 19).

Para comparar os diferentes cimentos, teste estatístico de múltiplas comparações foi aplicado aos diferentes terços, verificando sua significância entre os grupos irradiados e controle. 
No grupo controle cimentado com Unicem (grupo III) a resistência de união adesiva no terço médio foi estatisticamente superior ao grupo controle cimentado com Panavia F (grupo II, $p<0,01$ )

Não houve diferença estatisticamente significativa entre os grupos controle e irradiados com fibra axial para o uso do cimento Variolink II.

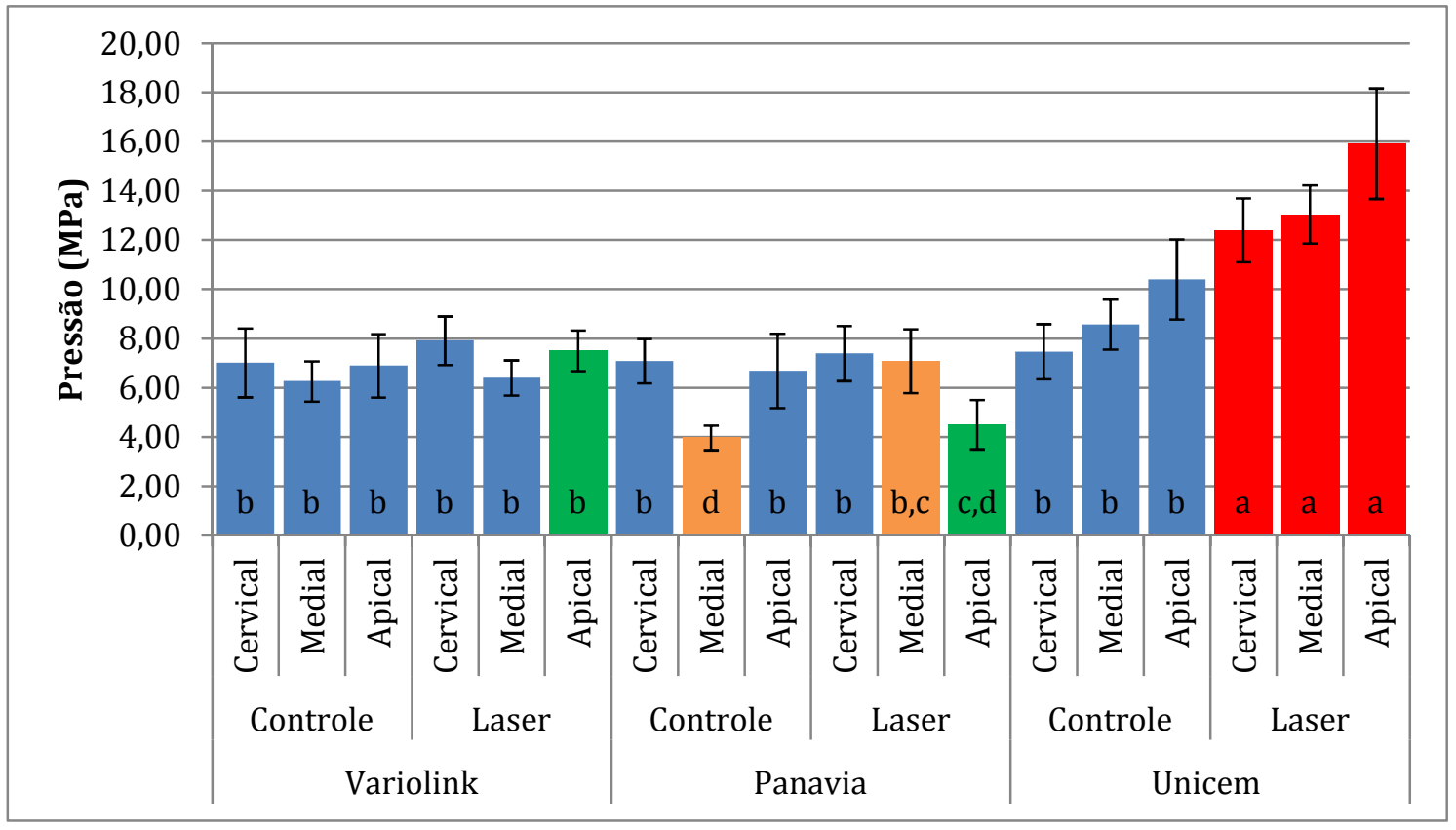

Figura 19: Resistência de união adesiva para os grupos controle e irradiados com fibras axiais em relação a cada terço avaliado. A barra indica o erro padrão.Letras diferentes representam diferenças estatísticas $(p<0,05)$

\subsubsection{Resultados da irradiação radial (side firing):}

Para analisar a influencia da irradiação nos grupos laser para os diferentes cimentos utilizados e a sua relação em cada terço, foi comparado com seu equivalente nos grupos controle. O nível de significância $p$ para a hipótese testada foi obtida pelo teste $\mathrm{t}$ juntamente com o nível de homogeneidade da variância obtida pelo teste de Levene está apresentada na Tabela 6 
Tabela 6: Níveis (p) corrigidos pelo teste de Ryan-Holm step down Bonferroni para comparação intra-grupos com fibra radial (side firing).

\begin{tabular}{|l|l|l|}
\hline & t-teste (p) & Levene (p) \\
\hline $\begin{array}{l}\text { Variolink Cerv. (contrl) vs. } \\
\text { Irradiado side firing Var. C. }\end{array}$ & 0,083620 & 0,012410 \\
\hline $\begin{array}{l}\text { Variolink Médio (contrl) vs. } \\
\text { Irradiado side firing Var. M }\end{array}$ & 0,016331 & 0,013900 \\
\hline $\begin{array}{l}\text { Variolink Apical (controle) vs. } \\
\text { Irradiado side firing Var. A }\end{array}$ & 0,001444 & 0,004482 \\
\hline $\begin{array}{l}\text { Panavia Cerv. (controle) vs. } \\
\text { Irradiado side firing Pan C }\end{array}$ & 0,000039 & 0,856892 \\
\hline $\begin{array}{l}\text { Panavi Médio (controle) vs. } \\
\text { Irradiado side firing Pan M }\end{array}$ & 0,000063 & 0,422248 \\
\hline $\begin{array}{l}\text { Panavia Apical (controle) vs. } \\
\text { Irradiado side firing Pan A }\end{array}$ & 0,000027 & 0,019686 \\
\hline $\begin{array}{c}\text { Unicem Cer.(Contrl) vs. } \\
\text { Irradiado side firing Unic. C. }\end{array}$ & 0,012290 & 0,310393 \\
\hline $\begin{array}{c}\text { Unicem Médio (Contrl) vs. } \\
\text { Irradiado side firing Unic. M }\end{array}$ & 0,687112 & 0,499235 \\
\hline $\begin{array}{c}\text { Unicem Apical (contrl) vs. } \\
\text { Irradiado side firing Unic. A. }\end{array}$ & 0,082100 & 0,011107 \\
\hline
\end{tabular}

Houve diferença estatisticamente significante quando comparado o grupo controle irradiado com fibra radial e cimentados com Variolink nas porções média e apical $(p<0,002)$ tendo a irradiação laser aumentado a resistência de união adesiva.

O grupo irradiado com fibra radial e cimentado com Panavia, tiveram maior resistência de união adesiva em relação a seus controles, para todos os terços $(p<0,0003$,

Para os grupos irradiados com fibra radial e cimentados com Unicem houve maior resistência de união adesiva para a região cervical quando comparado ao grupo controle $(p<0,02)$ 
Tabela 7: Níveis (p) corrigidos pelo teste de Ryan-Holm step-down Bonferroni para comparações entre-grupos controle. [ ${ }^{\star}$ Para $(p<0,05)$ foi utilizado o teste para variâncias diferentes].

\begin{tabular}{|c|c|c|}
\hline & anova & Levene \\
\hline Contole cervical & 0,195284 & 0,080901 \\
\hline Contole médio & não é possivel & $0,014770^{\star}$ \\
\hline Contole apical & não é possivel & $0,001197^{\star *}$ \\
\hline *Terço médio & Variolink & Panavia \\
\hline Panavia & 0,651706 & \\
\hline Unicem & $\underline{0,003684}$ & 0,005077 \\
\hline **Terço apical & Variolink & Panavia \\
\hline Panavia & 0,000730 & \\
\hline Unicem & 0,001653 & 0,000500 \\
\hline
\end{tabular}

Tabela 8: Níveis (p) corrigidos pelo teste de Ryan-Holm step-down Bonferroni para comparações entre-grupos irradiados com fibra radial (side firing)

\begin{tabular}{|c|c|c|}
\hline & anova & Levene \\
\hline Irradiado radial cervical & $\underline{0,026137^{*}}$ & 0,174469 \\
\hline Irradiado radial médio & não é possivel & $0,036488^{\star \star}$ \\
\hline Irradiado radial apical & 0,144886 & 0,157621 \\
\hline *Terço cervical & Variolink & Panavia \\
\hline Panavia & 0,188286 & \\
\hline Unicem & $\underline{0,023581}$ & 0,805538 \\
\hline **Terço médio & Variolink & Panavia \\
\hline Panavia & 0,611078 & \\
\hline Unicem & 0,677826 & 0,939933 \\
\hline
\end{tabular}


Uma avaliação entre grupos indica que no terço cervical dos grupos irradiados com fibra radial e cimentados com Unicem tiveram maior força de união adesiva quando comparados ao grupo irradiado com a mesma fibra, mas cimentados com Variolink ( $\mathrm{p}<0,003$, Tabela 8).

Para as amostras irradiadas com fibra side firing nos terços apical e médio não houve diferença estatisticamente significante na resistência de união adesiva para todos os cimentos utilizados ( $p>0,05$, Tabela 8$)$

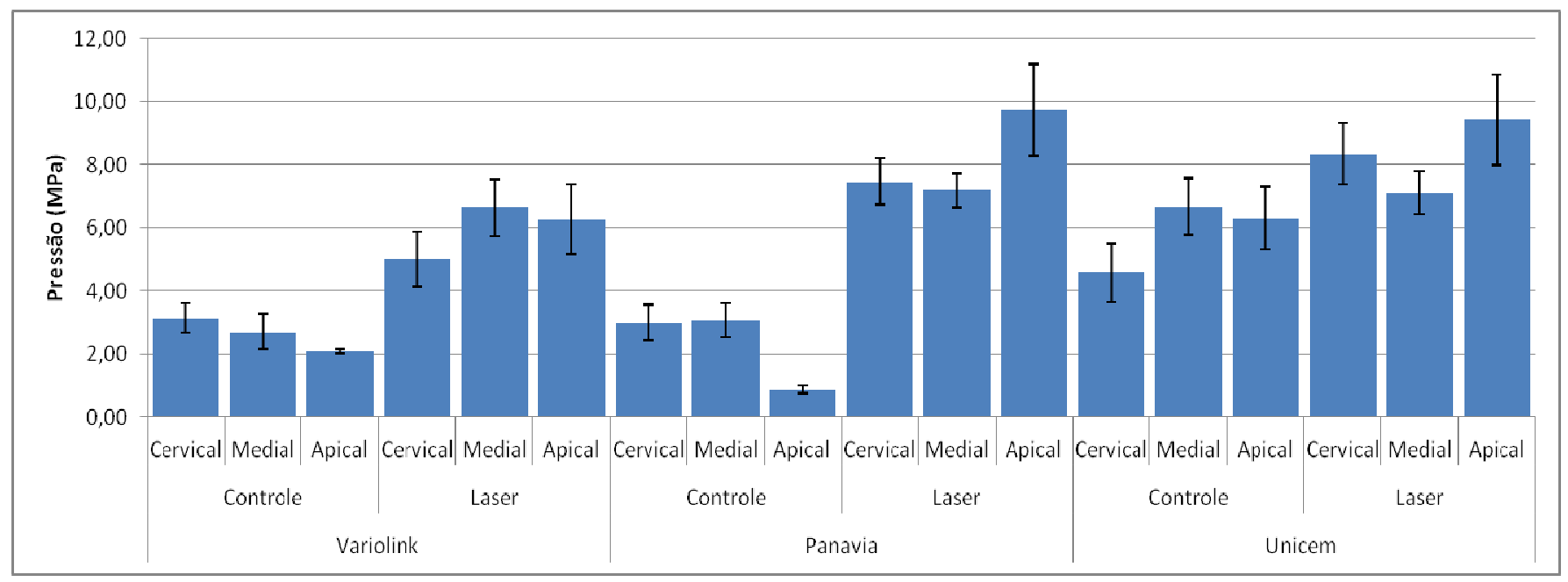

Figura 20: de união adesiva para os grupos controle e irradiados com fibras radiais (side firing) em relação a cada terço avaliado. A barra indica o erro padrão.

\subsubsection{Análise percentual entre os grupos controle e laser side firing}

Foi estimada também a melhora percentual entre os grupos controle e laser para a fibra side firing. Tal grandeza foi obtida dividindo-se a média de pressão do laser pela média de pressão dos grupos controle para todos os cimentos resinosos e terços estudados. Tais valores tiveram suas incertezas devidamente propagadas e, utilizando o teste $z$, determinou-se se há ou não indícios de melhora estatisticamente significativa. Os resultados obtidos para esta análise são apresentados na Tabela 9 
Tabela 9: Percentual de melhora entre os grupos controle e laser para todos os cimentos e todos os terços utilizando a fibra side firing

\begin{tabular}{|c|c|c|c|c|c|c|c|c|c|}
\hline & \multicolumn{3}{|c|}{ Variolink II } & \multicolumn{3}{|c|}{ Panavia F } & \multicolumn{3}{|c|}{ RelyX Unicem Aplc } \\
\hline & C & M & A & C & M & A & C & $\mathbf{M}$ & A \\
\hline 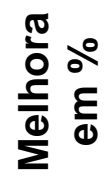 & 12,9 & 2,3 & 8,9 & 4,3 & 78,4 & $-32,6$ & 66,0 & 52,2 & 53,0 \\
\hline 立。 & 18,0 & 13,2 & 15,7 & 17,1 & 34,5 & 16,8 & 21,3 & 16,5 & 24,7 \\
\hline e & 0,473 & 0,864 & 0,572 & 0,801 & 0,023 & 0,053 & 0,002 & 0,002 & 0,032 \\
\hline
\end{tabular}

A Tabela 9 mostra que há uma melhora significativa $(p<0,05)$ na resistência de união adesiva em todos os terços do grupo RelyX Unicem Aplicap. Também se observa que há uma melhora significativa na resistência de união adesiva do terço médio com o cimento resinoso Panavia F (Figura 21)

Figura 21

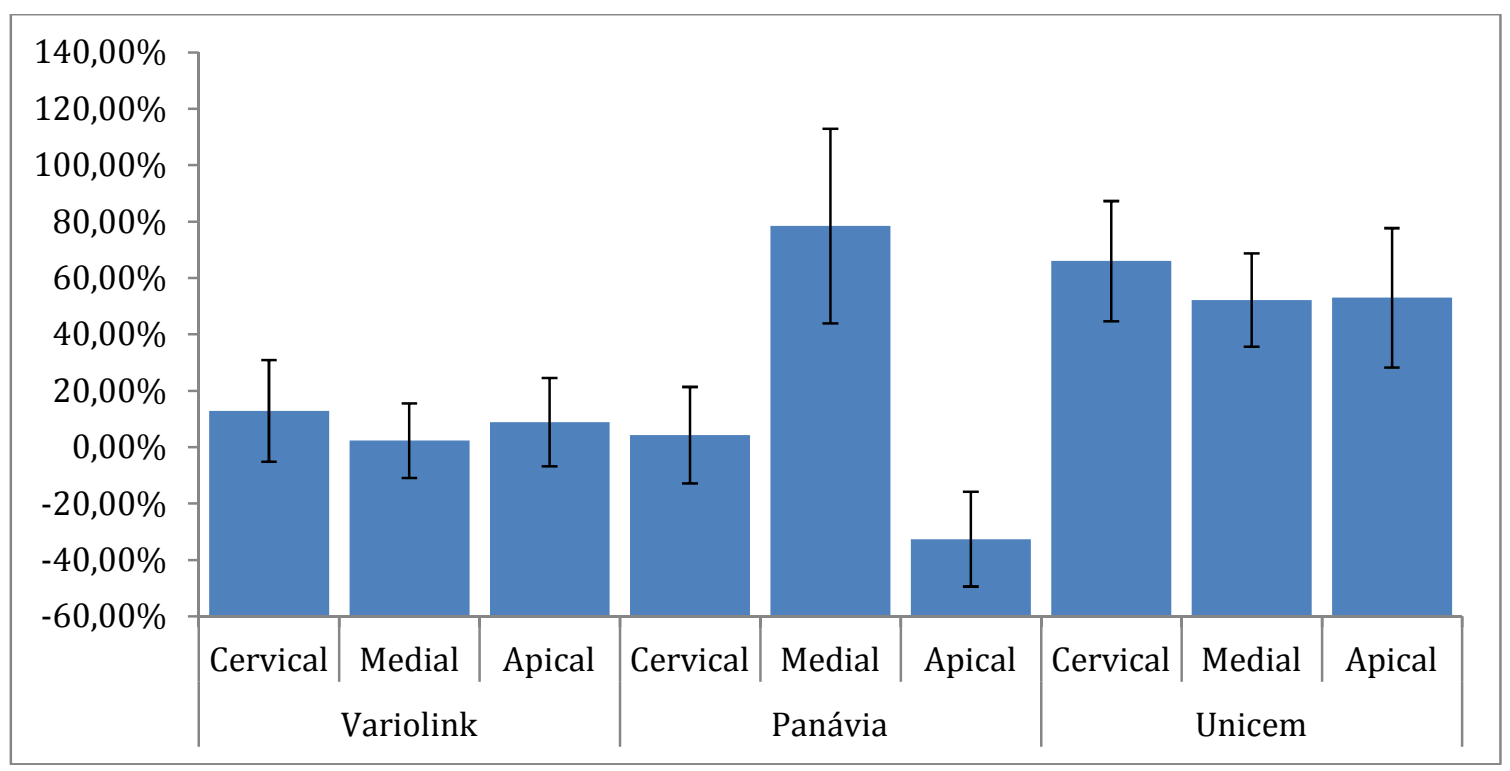

Figura 21: Percentual de melhora entre os grupos controle e laser para todos os cimentos e todos os terços utilizando a fibra side firing. 
A mesma análise foi efetuada para os dados obtidos na irradiação dos elementos dentais com a fibra radial (Tabela 10).

Tabela 10 Percentual de melhora entre os grupos controle e laser para todos os cimentos e todos os terços utilizando a fibra radial.

\begin{tabular}{|c|c|c|c|c|c|c|c|c|c|}
\hline & \multicolumn{3}{|c|}{ Variolink II } & \multicolumn{3}{c|}{ Panavia F } & \multicolumn{3}{c|}{ RelyX Unicem Aplc. } \\
\cline { 2 - 10 } & C & M & A & C & M & A & C & M & A \\
\hline Melhora $\%$ & $59 \%$ & $175 \%$ & $267 \%$ & $132 \%$ & $178 \%$ & $785 \%$ & $417 \%$ & $65 \%$ & $132 \%$ \\
\hline Erro \% & $29 \%$ & $45 \%$ & $73 \%$ & $31 \%$ & $35 \%$ & $148 \%$ & $71 \%$ & $23 \%$ & $36 \%$ \\
\hline P & 0,0408 & 0,0001 & 0,0002 & 0,0000 & 0,0000 & 0,0000 & 0,0000 & 0,0041 & 0,0003 \\
\hline
\end{tabular}

Na Tabela 10 observa-se que, diferente da irradiação com ponteira de fibra axial, há uma melhora estatisticamente significativa $(p<0,05)$ na resistência de união adesiva para todos os terços e cimentos após a irradiação utilizando uma fibra radial de maior abertura numérica (Figura 22).

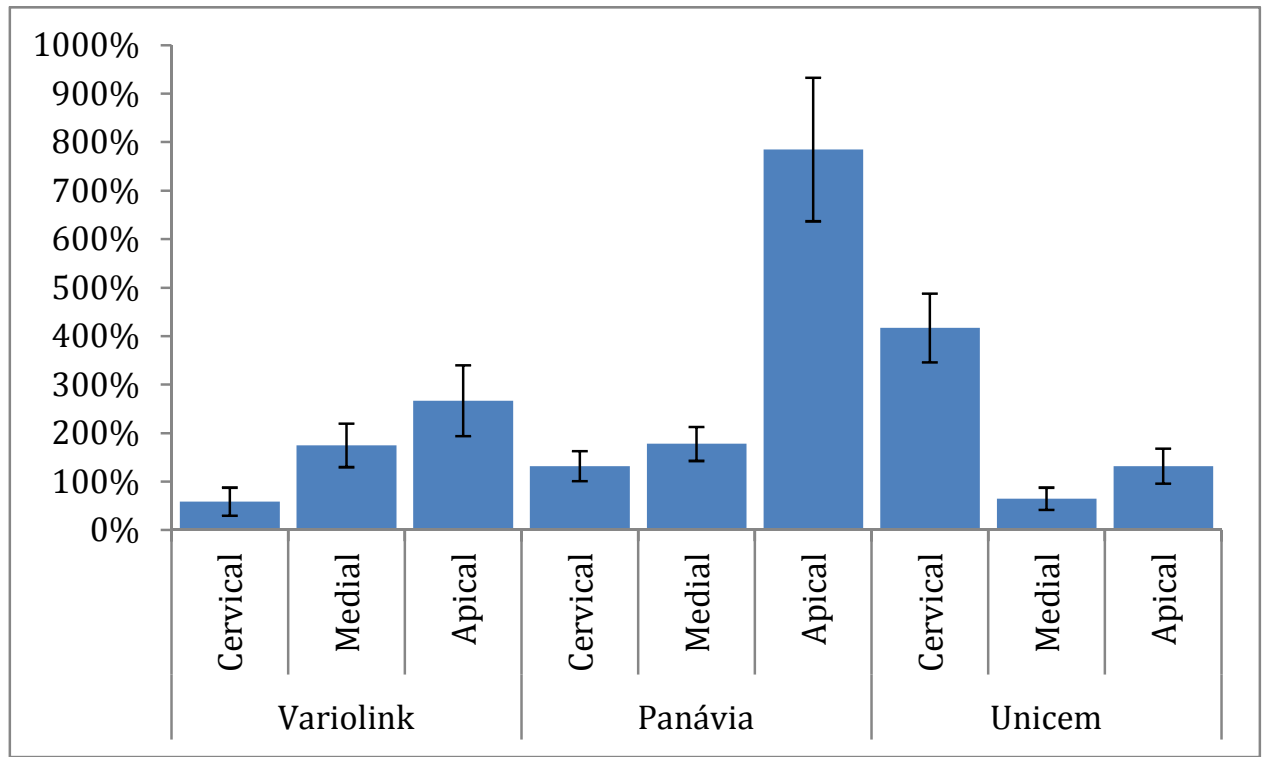

Figura 22 melhora percentual entre os grupos controle e laser para todos os cimentos e todos os terços utilizando a fibra radial. 


\section{DISCUSSÃO}

O uso clínico de um núcleo intracanal radicular requer a observação de uma extensa lista de cuidados profissionais. A reconstituição do elemento dental, o mais próximo possível das suas características originais, é uma meta a ser perseguida. A interface da estrutura dental com o material restaurador livre de contaminante potencializa as propriedades adesivas do material empregado, tornando o procedimento restaurador mais bem sucedido.

As condições experimentais dos parâmetros laser deste estudo permitiram a obtenção de uma superfície dentinária radicular livre de smear layer por ablação, com grande quantidade de túbulos abertos.

As características das superfícies obtidas reforçam a idéia que a utilização deste laser nas condições apresentadas, deixa a raiz muito mais receptiva para a utilização de qualquer cimento cujo principio de ação seja o embricamento mecânico. A maior quantidade de túbulos dentinários intracanal radiculares desobstruídos, significa aumento a área de superfície disponível, independentemente das características químicas dos cimentos utilizados.

A maior quantidade de túbulos abertos observados nas micrografias eletrônicas das amostras irradiadas (Figura 4 e Figura 5) está localizada na porção radicular que coincide com a região em que os núcleos foram instalados. Observam-se as imagens de MEV, superfícies mais limpas e maior quantidade de túbulos abertos com aspecto de corte da superfície dentinária. Densidades maiores causaram uma superfície com aspecto de fusão.

Em procedimentos adesivos sobre a dentina irradiada com laser de Er,Cr:YSGG a literatura ainda apresenta poucos estudos e que não apresentam um consenso. Alguns estudos, apesar de avaliarem a capacidade 
adesiva sobre a dentina foram conduzidos a partir de discos de dentina da região coronária. Entretanto, as condições anatômicas do conduto radicular, densidade de túbulos, propriedades ópticas do tecido alvo, dificuldade de adesão inerente ao conduto radicular ser diferente da coroa, as condições em que o feixe laser incide sobre a superfície da dentina, orientação do feixe em relação à orientação dos túbulos, a correta aferição da energia por pulso entregue pelo feixe são alguns parâmetros que precisam ser observados em ambos os casos e alteram o resultado final.

Com base no desenvolvimento deste estudo a mensuração da energia ou potência média de emissão do feixe laser entregue ao tecido alvo para determinar o real efeito é de fundamental importância, uma vez que só a padronização das condições experimentais permite o desenvolvimento de protocolos com resultados reprodutíveis e, portanto, passiveis de futuro uso clínico. O uso de um medidor de energia por pulso registra eventuais distorções não detectadas pela baixa resolução do display do aparelho emissor.

Neste estudo, verificou-se diferenças de até $100 \%$ entre o indicado pelo display, para a obtenção da mesma energia de $40 \pm 4 \mathrm{~mJ}$, mantidas as demais variáveis constantes. Este fato indica a necessidade de utilização deste recurso tanto em uso cientifico como clínico.

Durante a execução deste estudo o monitoramento foi constante e realizado a cada ciclo de irradiação. Alguns relatos da literatura onde não fica completamente clara a energia final entregue ao tecido alvo, não obtiveram o efeito de abertura de túbulos deste trabalho e, portanto, adversos à adesão ${ }^{50}$ causando controvérsia no uso do laser de Er,Cr:YSGG em procedimentos adesivos . 
A decomposição mineral do tecido ablacionado por ação térmica do laser pode alterar sua capacidade reativa frente à desmineralização por ácidos $^{44}$. Alterações morfológicas promovidas nos tecidos dentais irradiados com laser podem apresentar camadas de delaminação, e essas camadas podem levar ao insucesso do processo ablativo. Elevações de temperatura acima da faixa de $400^{\circ} \mathrm{C}$ promovem a formação de uma nova fase mineral da hidroxiapatita que aumenta a resistência à dissolução ácida. A caracterização precisa do feixe laser leva ao entendimento das alterações térmicas produzidas, seus efeitos estruturais e assim podemos entender as alterações químicas induzidas ${ }^{44}$ para cada condição de irradiação.

Somente o conhecimento preciso e bem definido sobre as condições do feixe laser aplicado e as características mais apuradas possíveis do tecido alvo, vão levar ao entendimento da qualidade dos resultados obtidos.

O trabalho realizado de forma padronizada por de Staninec et al. ${ }^{39}$ obteve para uma superfície dentinária humana irradiada com laser, resultados para resistência de união adesiva iguais ou superiores ao controle positivo (total-etching) estabelecendo todo o potencial do laser de Er,Cr:YSGG para procedimentos adesivos. Naquele estudo o feixe, com várias larguras temporais, incidiu perpendicularmente às amostras, com obtenção de superfícies uniformes com ausência completa de smear layer e com túbulos completamente abertos, desde que a densidade de energia excedesse o limiar de ablação, sem necessidade alguma de condicionamento ácido adicional, tendo os valores de resistência de união adesiva igual ou maiores que o grupo controle. Embora tenha sido utilizado um protótipo não comercial, seus 
resultados são úteis como uma base para as discussões referentes à utilização do laser neste comprimento de onda.

O laser é uma ferramenta muito precisa que quando bem utilizada leva a resultados de interesse clinico, mas que em contra partida apresenta uma complexidade operacional.

Como parte do presente estudo, avaliou-se os efeitos da direção de incidência do feixe laser de Er,Cr:YSGG em relação a direção dos túbulos dentinários radiculares e sua correlação com as alterações químicas produzidas nos terços cervical, médio e apical.

Os espectros de FTIR demonstraram que a composição dos túbulos é semelhante em qualquer área analisada (Figura 10). Foi possível observar diferença entre as amostras irradiadas e não irradiadas (Figura 12), como 0 alargamento da banda correspondente ao carbonato e amida II, o que pode indicar alterações na quantidade destes componentes na amostra após a irradiação, bem como ocorrência de mudanças estruturais com a irradiação. Esta alteração implica em alterações no colágeno, o que pode afetar a adesão com os sistemas self-etching e total-etching.

Conforme demonstrado pela literatura ${ }^{36,37,38}$, quer seja por sucessivas reflexões ou outro efeito ainda não esclarecido, há efeito anisotrópico pelo direcionamento do feixe laser quando este incide no mesmo eixo de orientação dos túbulos. Reforçando este efeito, há diferenças entre índices de refração nas diferentes regiões peritubular, intertubular e substância intertubular. Estudos adicionais são necessários para determinar e entender como podem afetar a superfície irradiada.

Decorre deste fato o desenvolvimento de fibras de entrega de feixe laser 
radial (side firing) que emitem fótons longitudinalmente aos túbulos. Como futuros trabalhos oriundos desta tese propõe-se a comparação de espectros de FTIR de dentina irradiada com fibra side-firing com os espectros obtidos neste estudo.

Com relação à resistência de união adesiva como todos os grupos irradiados apresentaram maiores valores médios de resistência de união adesiva em relação aos grupos controle, e como as energias utilizadas foram as que resultaram na melhor remoção de smear layer, então os parâmetros utilizados podem promover não só a abertura dos túbulos, limpeza da superfície como a melhor adesividade.

Devido a diferentes metodologias aplicadas na avaliação das fibras radial (side firing) e axial, não é possível estabelecer uma comparação adequada entre elas. Novos estudos serão necessários para comparar os efeitos sobre a união de resistência adesiva nas irradiações com laser de Er,Cr:YSGG com fibras do tipo axial e radial.

Como os grupos irradiados com fibra axial e cimentados com RelyX Unicem Aplicap apresentaram melhores resultados para todos os terços entre todos os grupos, e a cimentação se dá em dentina sem tratamento prévio, então este cimento é o mais indicado para ser utilizado quando o canal for irradiado, nas condições deste trabalho.

Os resultados para a região apical das amostras irradiadas com fibra radial em que o cimento tipo self-adhesive foi utilizado (RelyX Unicem Aplicap) apresentaram resistência de união adesiva muito superior aos grupos controle para a mesma região. Este fato se opõe ao resultado apresentado pelo estudo de Ziccari66, porém a diferença primordial está justamente no uso do laser. 
Deste fato pode-se inferir que a abertura dos túbulos dentinários promovida pela irradiação laser com fibra axial, revelaram uma área adesiva muito maior para a ação mais eficaz do RelyX Unicem Aplicap no terço apical.

Segundo Goracci ${ }^{64}$ é a presença de smear layer com a fraca atuação do acido fosfórico intracanal responsáveis pela baixa resistência da união adesiva dos sistemas total-etching na dentina com núcleos protéticos. Se nos grupos irradiados deste estudo o resultado na resistência de união adesiva com o uso do sistema total-etching foram superiores, então a remoção do smear layer promovida pelo laser, nos parâmetros deste estudo, associado ao ácido fosfórico melhoram as características do sistema total-etching.

A assertiva que as características estruturais da interface na dentina intracanal radicular pioram de qualidade do sentido cervical para apical, tanto na espessura quanto na quantidade de "tags" formados ${ }^{7}$, fica questionada se houver a aplicação laser de Er,Cr:YSGG nos parâmetros utilizados neste estudo.

Estudos morfológicos das falhas nas interfaces apontam que elas ocorrem majoritariamente na camada híbrida. A pouca penetração do adesivo na região apical está relacionada ao menor número de túbulos, o que determina menor resistência de união adesiva. A camada híbrida em sistemas do tipo total-etching geralmente é mais uniforme ${ }^{7}$. A maior quantidade de túbulos na região apical promovida pelo laser provavelmente seja mais exuberante que os promovidos pelo ácido do sistema total-etching. Estudos complementares são necessários para avaliar a influência da camada híbrida neste caso. 
$\mathrm{Na}$ dentina intracanal radicular após o processo de condicionamento ácido, houve um aumento na resistência de união adesiva. Isto se deve ao aumento na área de superfície da dentina e túbulos expostos, porém nem todas as áreas de dentina apresentam resposta semelhante frente ao uso do ácido fosfórico ${ }^{23,50}$. A uniformidade na remoção do smear layer e limpeza causadas pela irradiação com o laser de Er;Cr:YSGG promovendo uma maior quantidade de túbulos abertos, podem explicar sua superioridade nos processos adesivos da dentina irradiada, e possíveis alterações químicas.

No estudo de Bitter ${ }^{68}$, o grupo self-adhesive (FRC postec com RelyX Unicem Aplicap) apresentou melhor resistência de união adesiva no teste de push-out, concordando com os resultados deste estudo, mas naquele estudo foi notado que ocorria menor camada híbrida entre todos os outros grupos estudados. Além disso, também apresentava a pior distribuição tanto numérica quanto qualitativa em termos de penetração nos túbulos dentinários. No mesmo trabalho, discute-se a fraca hibridização com a dentina e que os monômeros ácidos devem desmineralizar e infiltrar no substrato dental, para assim criar retenção física e química. Naquele estudo assim como no grupo controle desta tese, a camada de smear layer não foi removida e obteve-se resultados satisfatórios de resistência de união adesiva, apesar disto. Porém é importante destacar que o grupo irradiado apresentou superioridade na resistência de união adesiva. Por similaridade se fossem comparados os resultados do grupo controle desta tese ao daquele estudo, poder-se-ia afirmar que o uso do laser sempre traz um resultado muito superior. É possível deduzir ainda que a presença do smear layer tenha efeito negativo a longo prazo e que deva ser minimizada sempre que possível. 
Os adesivos que utilizam a camada híbrida para sua fixação apresentam dificuldades no controle da umidade na intimidade do canal, não sendo possível a visualização do final do conduto, além do acesso ser mais difícil do que nos casos em que a dentina está completamente visível ${ }^{56}$. Estes fatos reforçam a vantagem do sistema self-adhesive após irradiação laser, como técnica de fácil aplicação e resultados superiores de adesividade em relação aos sistemas total-etching e self-etching.

Uma vez que o adesivo tipo self-etching necessita da camada de smear layer para fazer a sua ação, pois o mesmo não a remove e interage com a mesma propiciando o selamento da camada híbrida ${ }^{58}$. O mecanismo de ação deste sistema adesivo, explica por que as amostras irradiadas e cimentadas com ele apresentam uma resistência de união adesiva menor. A remoção do smear layer que é o substrato necessário para o adesivo tipo self-etching reduz igualmente sua capacidade adesiva. Este constatação vai de encontro a outros autores que apresentaram resultados inferiores para os grupos que usaram a técnica de self-etching ${ }^{51}$ em superfícies livres de smear layer. Esta assertiva concorda com estudos que demonstram que o uso de ácido fosfórico antes da aplicação de um primer do tipo self-etching reduz o resultado de resistência de união adesiva do cimento adesivo utilizado para a fixação de núcleos em fibra de vidro ${ }^{25}$.

As densidades de energia estudadas nesta tese estão de acordo com os trabalhos da literatura ${ }^{14,43,47,51}$ que indicam que a utilização do laser de Er,Cr:YSGG promove também a redução bacteriana que para o caos de irradiação intracanal prévia à cimentação de núcleos protéticos seria um efeito complementar bastante apropriado, uma vez que a cavidade oral é um local 
com alta prevalência de microorganismos ${ }^{12,13}$. Em um futuro uso clínico dos resultados desta tese pode-se assumir que além da redução do smear layer, na melhora da adesividade, dependendo do sistema adesivo utilizado, também será obtida uma significativa redução bacteriana antes da cimentação do núcleo. 


\section{CONCLUSÕES}

A irradiação intracanal radicular com laser de Er,Cr:YSGG nas condições deste estudo permite concluir que:

$\checkmark$ laser de Er,Cr:YSGG, promove a remoção de smear layer com conseqüente abertura dos túbulos dentinários nas diferentes regiões estudadas;

$\checkmark$ A melhor faixa de densidade de energia utilizada foi entre $32 \mathrm{~J} / \mathrm{cm}^{2}$ a $49 \mathrm{~J} / \mathrm{cm}^{2}$.

$\checkmark$ As superfícies mais limpas e com maior quantidade de túbulos abertos foram observadas nas porções média e cervical das raízes irradiadas;

$\checkmark$ Em nenhum dos parâmetros de energia utilizados houve aumento de temperatura maior do que $1,5^{\circ} \mathrm{C}$ na superfície externa da raiz (apical, médio ou cervical) durante a irradiação;

$\checkmark$ Pela análise dos espectros de FTIR, na região de número de onda entre 1800 a $700 \mathrm{~cm}^{-1}$, não há diferença na estrutura composicional dos espécimes sem irradiação analisados em cortes longitudinais ou transversais, mas há diferenças na quantidade de amida I e amida II após as irradiações.

$\checkmark$ Pelos mesmos critérios de análise dos espectros de FTIR, em amostras controle, não há diferença composicional nas bandas para as diversas porções dentais (apical, cervical e médio), porém as diferenças são nas proporções entre os compostos; 
$\checkmark$ Os grupos irradiados com fibra radial (side firing) e cimentados com RelyX Unicem Aplicap, obtiveram maior valor de resistência de união adesiva na região cervical, quando comparado aos grupos cimentados com Variolink ou Panavia $(0,023)$;

$\checkmark$ Os grupos irradiados com fibra axial e cimentados com RelyX Unicem Aplicap obtiveram os melhores resultados de resistência de união adesiva em todos os terços (cervical, médio e apical) e em relação aos demais tipos de cimento $(p<0,035)$. 


\section{REFERÊNCIAS}

1 DIETSCHI D.; DUC O.; KREJCI I.; SADAN A. Biomechanical considerations for the restoration of endodontically treated teeth: a systematic review of the literature--Part 1. Composition and micro and macrostructure alterations. Quintessence Int., 38(9), 733-743, 2007

2 POWERS J.M.; O'KEEFE K.L.; PINZON L.M. Factors affecting in vitro bond strength of bonding agents to human dentin. Odontology ,91(1), 1-6, 2003.

3 HUANG TJ.; SCHILDER H.; NATHANSON D. Effects of moisture content and endodontic treatment on some mechanical properties of human dentin. $\boldsymbol{J}$. Endod. 18(5), 209-15, 1992.

4 MEREDITH, N.; SHERRIFF, M.; SETCHELL, D. J.; SWANSON, S. A. Measurement of the microhardness and Young's modulus of human enamel and dentine using an indentation technique. Arch Oral Biol., 41(6), 539-45, 1996.

5 KINNEY, J. H.; BALOOCH, M.; MARSHALL, S. J.; MARSHALL, G. W.; WEIHS, T. P. Hardness and Young's modulus of human peritubular and intertubular dentine. Arch Oral Biol., 41(1), 9-13, 1996.

6 TORBJÖRNER, A.; FRANSSON, B.A. Literature review on the prosthetic treatment of structurally compromised teeth. Int. J. Prosthod., 17(3), 369-376, 2004.

7 DIETSCHI D.; DUC O.; KREJCI I.; SADAN A. Biomechanical considerations for the restoration of endodontically treated teeth: a systematic review of the literature, Part II (Evaluation of fatigue behavior, interfaces, and in vivo studies). Quintessence Int., 39(2), 117-129, 2008. 
8 NEWMAN M.P.; YAMAN P.; DENNISON J.; RAFTER M.; BILLY E. Fracture resistance of endodontically treated teeth restored with composite posts. $\boldsymbol{J}$ Prosthet Dent., 89(4), 360-7, 2003.

9 ROSENSTIEL, S. F.; LAND, M. F.; CRISPIN, B. Dental luting agents: A review of the current literature. J Prosthet Dent., 80(3), 280-301, 1998.

10 SIMONETTI M.; RADOVIC I.; VANO M.; CHIEFFI N.; GORACCI C.; TOGNINI F.; ET AL. The influence of operator variability on adhesive cementation of fiber posts. $\boldsymbol{J}$ Adhes Dent., 8(6), 421-5, 2006.

11 SLY, M.M.; MOORE, K.; PLATT A.J.; BROWN C.E. Push-Out Bond Strength of a New Endodontic Obturation System (Resilon/Epiphany). J.Endod., 33(2), 160-162, 2007.

12 LOVE, R. M.; JENKINSON, H. F. Invasion of dentinal tubules by oral bacteria. Crit Rev Oral Biol Med., 13(2), 171-183, 2002.

13 AAS, J. A.; PASTER, B. J.; STOKES, L. N.; OLSEN, I.; DEWHIRST, F. E. Defining the normal bacterial flora of the oral cavity. J Clin Microbiol., 43(11), 5721-5732, 2005.

14 SCHOOP, U.; BARYLYAK, A.; GOHARKHAY, K.; BEER, F.; WERNISCH, J.; GEORGOPOULOS, A.; SPERR, W.; ET AL. The impact of an erbium, chromium:yttrium-scandium-gallium-garnet laser with radial-firing tips on endodontic treatment. Lasers Med Sci., 24(1), 59-65, 2009.

15 BERUTTI E.; MARINI R.; ANGERETTI A. Penetration ability of different irrigants into dentinal tubules. J Endod., 23, 725-727, 1997.

16 VANO M.; CURY A.H.; GORACCI C.; CHIEFFI N.; GABRIELE M.; TAY F.R.; ET AL. The effect of immediate versus delayed cementation on the 
retention of different types of fiber post in canals obturated using a eugenol sealer. J Endod., 32(9), 882-885, 2006.

17 SIQUEIRA, J. F.; RÔÇAS, I. N.; FAVIERI, A.; ABAD, E. C.; CASTRO, A. J.; GAHYVA, S. M. Bacterial leakage in coronally unsealed root canals obturated with 3 different techniques. Oral Surg. Oral Med. Oral Pathol. Oral Radiol. Endod., 90(5), 647-50, 2000

18 BARTHEL, C.R.; ZIMMER, S.; WUSSOGK, R. Long-Term Bacterial Leakage along Obturated Roots Restored with Temporary and Adhesive Fillings. J Endod., 27(9), 559-562, 2001.

19 MJÖR, I. A.; NORDAHL, I. The density and branching of dentinal tubules in human teeth. Arch Oral Biol., 41(5), 401-12,1996.

20 PASHLEY, D.; OKABE, A.; PARHAM, P. The relationship between dentin microhardness and tubule density. Endod Dent Traumatol., 1(5), 176-9, 1985.

21 POOLTHONG, S.; MORI, T.; SWAIN, M. V. Determination of elastic modulus of dentin by small spherical diamond indenters. Dent Mater J., 20(3), 227-236, 2001.

22 PALAMARA, J. E.; WILSON, P. R.; THOMAS, C. D.; MESSER, H. H. A new imaging technique for measuring the surface strains applied to dentine. $\boldsymbol{J}$ Dent., 28(2), 141-6, 2000.

23 FERRARI, M.; MANNOCCI, F.; VICHI, A., CAGIDIACO, M. C.; MJÖR, I. A. Bonding to root canal: structural characteristics of the substrate. Am J Dent., 13(5), 255-60, 2000. 
24 GU, X.H.; MAO, C.Y.; LIANG, C.; WANG, H.M.; KERN, M. Does endodontic post space irrigation affect smear layer removal and bonding effectiveness? Eur J Oral Sci., 117(5), 597-603, 2009.

25 POWERS, J. M.; O'KEEFE, K.L.; PINZON, L.M. Factors affecting in vitro bond strength of bonding agents to human dentin. Odontology , 91(1), 1-6, 2003.

26 CARVALHO, C. A.; CANTORO, A.; MAZZONI, A.; GORACCI, C.; BRESCHI, L.; FERRARI, M. Effect of ethanol application on post-luting to intraradicular dentine. Int Endod J., 42(2), 129-35, 2009.

27 ERDEMIR, A.; ARI, H.; GÜNGÜNEŞ, H.; BELLI, S. Effect of medications for root canal treatment on bonding to root canal dentin. J Endod., 30(2), 1136, 2004.

28 SHAHRAVAN, A.; HAGHDOOST, A.A.; ADL, A.; RAHIMI, H.; SHADIFAR, $F$. Effect of smear layer on sealing ability of canal obturation: a systematic review and meta-analysis. J Endod., 33(2), 96-105, 2007.

29 PASHLEY, D. H. Smear layer: physiological considerations. Oper Dent n 3, p 13-29, 1984. Supplement.

30 PASHLEY, D. H.; CIUCCHI, B.; SANO, H.; HORNER, J. A. Permeability of dentin to adhesive agents. Quintessence Int., 24(9), 618-31, 1993.

31 AYAD, M. F. Lactic acid root canal irrigation for dowel and core treatment: a pilot study J Prosthet Dent., 92(6), 540-5, 2004.

32 HÜLSMANN, M.; HECKENDORFF, M.; LENNON, A. Chelating agents in root canal treatment: mode of action and indications for their use. Int Endod J., 36(12), 810-30, 2003. 
33 MOUNTOURIS, G.; SILIKAS, N.; ELIADES, G. Effect of sodium hypochlorite treatment on the molecular composition and morphology of human coronal dentin. J Adhes Dent., 6(3), 175-82, 2004

34 PASHLEY, D.H.; CARVALHO, R.M. Dentine permeability and dentine adhesion. J Dent., 25(5), 355-72, 1997.

35 FRIED, D.; FEATHERSTONE, J.D.B.; VISURI, S.R.; SEKA, W.; WALSH, J.T. The Caries Inhibition Potential of Er:YAG and Er:YSGG Laser Radiation. SPIE proceedings: Lasers in Dentistry II, v. 2672, p. 73-78, 1996.

36 KIENLE, A.; HIBST, R. Light guiding in biological tissue due to scattering. Phys Rev Lett., 97(1), 018104, 2006.

37 KIENLE, A.; FORSTER, F.K.; DIEBOLDER, R.; HIBST, R. Light propagation in dentin: influence of microstructure on anisotropy. Phys Med Biol. 21; 48(2), N7-14 2003.

38 KIENLE A.; MICHELS R.; HIBST R. Magnification-a new look at a longknown optical property of dentin, J Dent Res. 85(10), 955-9, 2006.

39 STANINEC, M.; GARDNER, A.K.; LE, C.Q.; SARMA, A.V.; FRIED, D. Adhesion of composite to enamel and dentin surfaces irradiated by IR laser pulses of 0.5-35 micros duration. J Biomed Mater Res B Appl Biomater. 79(1), 193-201, 2006.

40 ESTEVES-OLIVEIRA, M., ZEZELL, D. M., APEL, C., TURBINO, M. L., ARANHA, A. C. C., EDUARDO, C. D. P., GUTKNECHT, N. Bond strength of self-etching primer to bur cut, Er,Cr:YSGG, and Er:YAG lased dental surfaces. Photomed Laser Surg., 25(5), 373-80. 2007. 
41 FERREIRA, L. S., APEL, C., FRANCCI, C., SIMOES, A., EDUARDO, C. P., GUTKNECHT, N. Influence of etching time on bond strength in dentin irradiated with erbium lasers. Lasers Med Sci., 25(6), 849-54, 2010.

42 TACHiBANA, A.; MARQUES, M. M.; SOlER, J. M. P.; MATOS, A. B. Erbium, chromium:yttrium scandium gallium garnet laser for caries removal: influence on bonding of a self-etching adhesive system. Lasers Med Sci., 23(4), 435-4, 2008.

43 YAVARI, H. R.; RAHIMI, S.; SHAHI, S.; LOTFI, M.; BARHAGHI, M. H. S.; FATEMI, A.; ABDOLRAHIMI, M. Effect of Er,Cr:YSGG laser irradiation on Enterococcus faecalis in infected root canals. Photomed Laser Surg., 28 Suppl 1, S91-6, 2010.

44 FRIED, D.; ASHOURI, N.; BREUNIG, T.; SHORI, R. Mechanism of water augmentation during IR laser ablation of dental enamel. Lasers Surg Med., 31(3), 186-93, 2002.

45 FEATHERSTONE J.D.B.; FRIED D.; DUHN C. Surface dissolution kinetics of dental hard tissue irradiated over a fluence range of 1-8 J/cm2 at a wavelength of $9.3 \mathrm{~mm}$. SPIE proceedings Lasers in Dentistry IV, Vol. 3248, 146-151, 1998.

46 SECILMIS, A.; ALTINTAS, S.; USUMEZ, A.; BERK, G. Evaluation of mineral content of dentin prepared by erbium, chromium:yttrium scandium gallium garnet laser. Lasers Med Sci., 23(4), 421-5, 2008.

47 FRANZEN, R.; ESTEVES-OLIVEIRA, M.; MEISTER, J.; WALLERANG, A.; VANWEERSCH, L.; LAMPERT, F.; GUTKNECHT, N. Decontamination of deep dentin by means of erbium, chromium:yttrium-scandium-gallium-garnet laser irradiation. Lasers Med Sci., 24(1), 75-80, 2009.

48 MINAS, N. H.; MEISTER, J.; FRANZEN, R.; GUTKNECHT, N.; LAMPERT, $F$. In vitro investigation of intracanal dentine-laser beam interaction aspects: I. 
Evaluation of ablation capability (ablation rate and efficiency). Lasers Med Sci., 25(6), 835-40, 2010.

49 GEORGE, R.; WALSH, L. J. Performance assessment of novel side firing flexible optical fibers for dental applications. Lasers Surg Med., 41(3), 214-21, 2009 .

50 LEE, B.S.; LIN, P.Y.; CHEN, M.H.; HSIEH, T.T.; LIN, C.P.; LAI, J.Y.; LAN, W.H. Tensile bond strength of Er,Cr:YSGG laser-irradiated human dentin and analysis of dentin-resin interface. Dent Mater., 23(5), 570-578, 2007.

51 CELIK, C.; OZEL, Y.; BAĞIŞ, B.; ERKUT, S. Effect of laser irradiation and cavity disinfectant application on the microtensile bond strength of different adhesive systems. Photomed Laser Surg., 28(2), 267-72, 2010.

52 PINZON, L. M.; POWERS, J. M.; O'KEEFE, K. L.; DUSEVISH, V.; SPENCER, P.; MARSHALL, G. W. (2011). Effect of mucoprotein on the bond strength of resin composite to human dentin. Odontology, 99(2), 119-28, 2011.

53 RADOVIC, I.; MONTICELLI, F.; GORACCI, C.; VULICEVIC, Z. R.; FERRARI, M. Self-adhesive resin cements: a literature review. $\boldsymbol{J}$ Adhes Dent., 10(4), 251-8, 2008.

54 BOONE, K. J.; MURCHISON, D. F.; SCHINDLER, W. G.; WALKER, W. A. Post retention: the effect of sequence of post-space preparation, cementation time, and different sealers. J Endod., 27(12), 768-71, 2001.

55 FEILZER, A. J.; DE GEE, A. J.; DAVIDSON, C. L. Setting stress in composite resin in relation to configuration of the restoration. J Dent Res., 66(11), 1636-9, 1987. 
56 BOUILLAGUET, S.; TROESCH, S.; WATAHA, J. C.; KREJCI, I.; MEYER, J. M.; PASHLEY, D. H. Microtensile bond strength between adhesive cements and root canal dentin. Dent Mater., 19(3), 199-205, 2003.

57 MARSHALL, G. W.; MARSHALL, S. J.; KINNEY, J. H.; BALOOCH, M. The dentin substrate: structure and properties related to bonding. J Dent., 25(6), 441-58, 1997.

58 ROSALES-LEAL, J. I.; DE LA TORRE-MORENO, F. J.; BRAVO, M. Effect of pulp pressure on the micropermeability and sealing ability of etch \& rinse and self-etching adhesives. Oper Dent., 32(3), 242-50, 2007.

59 LIU, J.; HATTORI, M.; HASEGAWA, K.; YOSHINARI, M.; KAWADA, E.; ODA, Y. Effect of tubule orientation and dentin location on the microtensile strength of bovine root dentin. Dent Mater, 21(2), 73-82, 2002.

60 DEMIRYÜREK, E. O.; KÜLÜNK, S.; SARAÇ, D.; YÜKSEL, G.; BULUCU, B. Effect of different surface treatments on the push-out bond strength of fiber post to root canal dentin. Oral Surg. Oral Med. Oral Pathol. Oral Radiol. Endod. 108(2), e74-80, 2009.

61 NAUMANN, M.; STERZENBACH, G.; ROSENTRITT, M.; BEUER, F.; FRANKENBERGER, R. Is adhesive cementation of endodontic posts necessary? J Endod., 34(8), 1006-10, 2, 2008.

62 GORACCI, C.; GRANDINI, S.; BOSSÙ, M.; BERTELLI, E.; FERRARI, M. Laboratory assessment of the retentive potential of adhesive posts: a review. J Dent., 35(11), 827-35, 2007.

63 SOARES, C.; SANTANA, F.; CASTRO, C. Finite element analysis and bond strength of a glass post to intraradicular dentin: comparison between microtensile and push-out tests. Dent Mater., 4, 1405-1411, 2008. 
64 GORACCI, C.; TAVARES, A. U.; FABIANELLI, A.; MONTICELLI, F.; RAFFAELLI, O.; CARDOSO, P. C.; TAY, F.; ET AL. The adhesion between fiber posts and root canal walls: comparison between microtensile and pushout bond strength measurements. Eur J Oral Sci., 112(4), 353-61, 2004.

65 SOUZA, Soráia de Fátima Carvalho. Cimentos resinosos endodônticos: selamento apical, aspectos micromorfológicos, características físicas e resistência de união à dentina. 2007. Tese (Doutorado em Materiais Dentários) - Faculdade de Odontologia, Universidade de São Paulo, São Paulo, 2007. Disponível em: <http://www.teses.usp.br/teses/disponiveis/23/23140/tde09042009-120215/>. Acesso em: 27/05/2009.

66 ZICARI, F.; COUTHINO, E.; DE MUNCK, J.; POITEVIN, A.; SCOTTI, R.; NAERT, I.; VAN MEERBEEK, B. Bonding effectiveness and sealing ability of fiber-post bonding. Dent Mater. 24(7), 967-77, 2008.

67 RADOVIC, I.; MAZZITELLI, C.; CHIEFFI, N.; FERRARI, M. Evaluation of the adhesion of fiber posts cemented using different adhesive approaches. Eur J Oral Sci., 116(6), 557-63. 2008

68 BITTER, K.; PARIS, S.; PFUERTNER, C.; NEUMANN, K.; KIELBASSA, A.M. Morphological and bond strength evaluation of different resin cements to root dentin. Eur J Oral Sci., 117(3), 326-33, 2009.

69 Technical Specification, ISO/TS \# 11405, Dental materials - Testing of adhesion to tooth structure, Second edition, 2003-02-01, Reference number: ISO/TS 11405:2003(E).

70 YAMAZAKI R.; GOYA C,.; YU DG.; KIMURA Y.; MATSUMOTO K. Effects of erbium,chromium:YSSGG laser irradiation on root canal walls: a scanning electron microscopic and thermographic study. J Endod., v. 27, n. 1, p. 9-12, 2001. 
71 YU J.T.; WANG X.D.; BAO M.R.; YAN L. Research on the effect of root canal seal achieved by irradiation of Er,Cr:YSGG laser. Shangai Kou Qinag Yi Xue. v. 13, n. 1, p. 27-9. 2004.

72 ERIKSSON, R.A.; ALBREKTSSON, T.; Temperature threshold levels for heat-induced bone tissue injury: A vital-microscopic study in the rabbit, $\boldsymbol{J}$ Prosthet Dent., 50(01), 101-107, 1983.

73

http://www.forp.usp.br/restauradora/rotatórios/protaper_plus/protaper_plus.pdf, acessada em 27/5/2009.

74 RIBEIRO, A.C.; NOGUEIRA, G.E.C.; ANTONIZAZZI, J.H.; MORITZ, ZEZELL, D.M.; Effects of Diode Laser $(810 \mathrm{~nm})$ irradiation on root canal walls: Thermografic and morphological studies, J Endod., 33(3), 252-5, 2007.

75 QUINTO JR., J.; ARCHILLA, J. R. F.; PELINO, J. E. P.; MARTINS, V. R. G.;WETTER, N. U.; MARQUES, M. M.; EDUARDO, C. P. Morphological and temperature analysis of root canal dentin after Er,Cr:YSGG laser irradiation, 3ESOLA proceedings, 11, 2005.

76 BARYLYAK, A.; BOBYTSKYY, Y., Waveguide Properties of Tooth, 5ESOLA proceedings, 15, 2009.

77 BACHMANN, L.; ZEZELL, D.M. Estrutura e composição de esmalte e dentina. São Paulo, S.P.: Editora Livraria da Física, 2005.

78 http://www.biolase.com/products/waterlasemd/images/endo.pdf, acessado em 27/05/2009.

79 SADEK, F.T.; GORACCI, C.; MONTICELLI, F.; GRANDINI, S.; CURY, A.H.; TAY, F.; FERRARI, M. Immediate and 24-hour evaluation of the interfacial strengths of fiber posts. J Endod., 32(12), 1174-7, 2006. 